\title{
Profits and Balance Sheet Developments at U.S. Commercial Banks in 2009
}

Seung Jung Lee and Jonathan D. Rose, of the Board's Division of Monetary Affairs, prepared this article. Thomas C. Allard and Mary E. Chosak assisted in developing the database underlying much of the analysis. Michael Levere and Robert Kurtzman provided research assistance.

The U.S. commercial banking sector remained under significant pressure in 2009. Bank profitability was damped by the effects of the weak economy on asset quality and lending activity, with loan delinquency and charge-off rates rising to historical highs in many cases and banks' balance sheets contracting. Reflecting the weak portfolios and low profitability that weighed on the sector as a whole, 120 smaller banks failed during the year, and the watch list of the Federal Deposit Insurance Corporation (FDIC) expanded to include about 700 institutions by year-end, the highest levels for both of these measures since the early 1990s. By contrast, the acute strains the largest

Note: The data in this article cover insured domestic commercial banks and nondeposit trust companies (hereafter, banks). Except as otherwise indicated, the data are from the Consolidated Reports of Condition and Income (Call Report). The Call Report consists of two forms submitted by domestic banks to the Federal Financial Institutions Examination Council: FFIEC 031 (for those with domestic and foreign offices) and FFIEC 041 (for those with domestic offices only). The data thus consolidate information from foreign and domestic offices, and they have been adjusted to take account of mergers and the effects of push-down accounting. For additional information on the adjustments to the data, see the appendix in William B. English and William R. Nelson (1998), "Profits and Balance Sheet Developments at U.S. Commercial Banks in 1997," Federal Reserve Bulletin, vol. 84 (June), p. 408. Size categories, based on assets at the start of each quarter, are as follows: the 10 largest banks, large banks (those ranked 11 through 100), medium-sized banks (those ranked 101 through 1,000 ), and small banks (those ranked 1,001 and higher). At the start of the fourth quarter of 2009, the approximate asset sizes of the banks in those groups were as follows: the 10 largest banks, more than $\$ 166$ billion; large banks, $\$ 7.9$ billion to $\$ 165$ billion; medium-sized banks, $\$ 527.3$ million to $\$ 7.9$ billion; and small banks, less than $\$ 527.3$ million.

Data shown in this article may not match data published in earlier years because of revisions and corrections. The data reflect information available as of April 20, 2010, unless noted otherwise. In the tables, components may not sum to totals because of rounding. Appendix tables A.1.A through A.1.E report portfolio composition, interest rates, and income and expense items, all as a percentage of overall average net consolidated assets, for all banks and for banks in each of the four size categories. Appendix table A.2 reports income statement data for all banks. banks faced in late 2008 abated over the first half of 2009 , largely because of unprecedented interventions by the Treasury, the Federal Reserve, and the FDIC.

Asset quality worsened for all major loan classes over 2009, but real estate loans backed by residential and by commercial properties remained at the center of banks' credit quality problems. Conditions in the real estate sector generally stayed weak, especially in commercial markets. House prices continued declining sharply in the first half of the year but were more stable in the second half. The stabilization of prices partly reflects stronger demand for housing that was likely spurred in part by low mortgage rates, which were fostered partly by the Federal Reserve's purchases of agency debt and mortgage-backed securities (MBS). A tax credit for first-time homebuyers also helped support housing demand. Still, with many households' mortgage obligations exceeding the value of their houses, 1.4 million properties entered foreclosure over the year.

Aggregate economic activity picked up in the second half of the year after several quarters of contraction, stimulated by monetary and fiscal expansions, increased foreign growth, and improvements in financial market conditions. However, as is typical in cyclical economic recoveries, the improvement in labor market conditions lagged the trends in economic activity, and the unemployment rate reached 10 percent at year-end before edging lower. The weakness in labor markets contributed to historically elevated delinquency and charge-off rates on consumer credit card loans. The deterioration in credit quality across all loan categories led to a further rise in already elevated rates of loss provisioning. Consequently, the profitability of the commercial banking industry was depressed, and return on assets (ROA) and return on equity (ROE) were both at their lowest annual levels since at least 1985 (figure 1). ${ }^{1}$

1. It is worth emphasizing that the analysis in this article is based on Call Reports for commercial banks. For a commercial bank that is a subsidiary of a bank holding company or a financial holding company, the Call Report does not include the assets, liabilities, income, or expenses of the other subsidiaries of the larger organization. Thus, the 
1. Bank profitability, 1985-2009

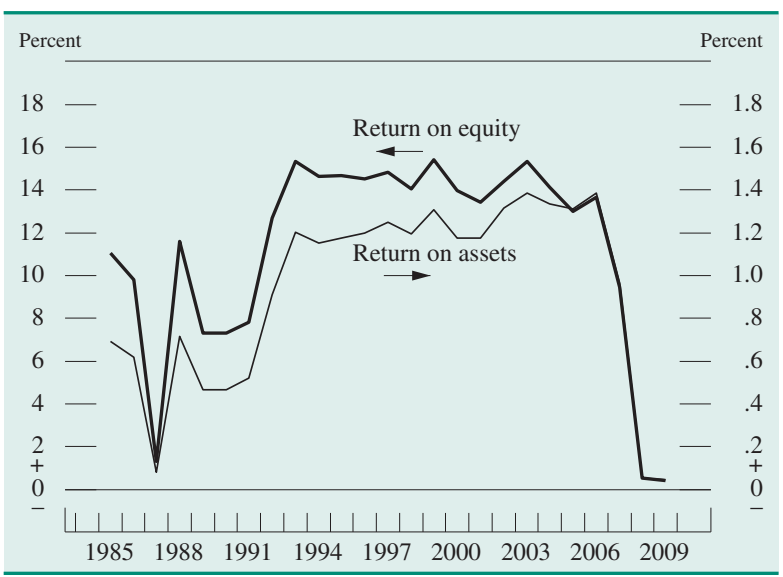

Note: The data are annual.

SOURCE: Here and in subsequent figures and tables except as noted, Federal Financial Institutions Examination Council, Consolidated Reports of Condition and Income (Call Report).

Profitability diverged between the largest banking institutions and the rest of the industry, primarily reflecting the ability of large banks to generate income from specialized activities in which other banks do not generally participate. Indeed, large banks, taken together, posted a small profit last year, as trading revenue rebounded to pre-crisis levels with the improvements in capital markets and income from net servicing fees increased. Those revenues managed to offset the pressures on earnings at these banks caused by the further deterioration in credit quality. In addition, large banks experienced a substantial inflow of core deposits at very low interest rates, which improved their net interest margins. In contrast, profits at small and medium-sized banks declined further, weighed down by higher loan losses that were not offset by other forms of revenue.

The commercial banking sector deleveraged over 2009 as banks raised capital and nominal assets posted an annual decline for the first time since 1948. Loans outstanding declined-across all major loan categories, but especially in loans to businessesconsistent with reports of banks' more stringent lending posture and reduced demand for loans from creditworthy borrowers. Borrowers such as households and small businesses with more limited access to nonbank sources of credit were particularly affected by the tight lending conditions.

Demand for bank loans was further held down by the efforts of households and businesses to rebuild their balance sheets. Consumer spending stabilized in

profits of the commercial banks that are subsidiaries of a larger banking organization may differ substantially from the profits of the consolidated institution. the first half of the year and expanded thereafter, reflecting the improvement in financial market prices and accommodative monetary and fiscal policies. However, households financed the increase in consumer outlays primarily out of disposable income. On the business side, commercial real estate (CRE) activity contracted sharply. Businesses' spending on equipment and software picked up in the second half of the year, probably owing in part to improved conditions in the bond market and some increase in sales prospects. Indeed, large reductions in corporate bond spreads spurred robust issuance of both investmentand speculative-grade bonds, and large firms reportedly paid down some bank loans with the proceeds of such bond issues.

Throughout the year, the Federal Open Market Committee maintained a target range for the federal funds rate of 0 to $1 / 4$ percent to foster economic recovery. The Federal Reserve extended through early 2010 most of the special credit and liquidity programs that it had established at the height of the crisis. However, as financial market functioning improved over 2009, these facilities generally declined in size (figure 2), and on February 1, 2010, most expired. ${ }^{2}$ The Term Asset-Backed Securities Loan Facility, which was designed to increase credit availability and support economic activity by facilitating renewed issuance of consumer and business asset-backed securities (ABS) at more-normal interest rate spreads, continued operating into 2010. Together, the support provided by all of these programs helped reduce strains in funding markets and bolster liquidity in financial markets more broadly.

To provide support to mortgage lending and housing markets and to improve overall conditions in private credit markets, the Federal Reserve announced large-scale asset purchases of government-sponsored enterprise (GSE) debt and agency MBS in late 2008. In March 2009, those programs were enlarged, and the Federal Reserve also announced a program of purchases of Treasury securities. The Federal Reserve concluded purchasing $\$ 1.25$ trillion of agency MBS and about $\$ 175$ billion of agency debt in March 2010,

2. The following programs expired on February 1, 2010: AssetBacked Commercial Paper Money Market Mutual Fund Liquidity Facility; Commercial Paper Funding Facility; Primary Dealer Credit Facility; Term Securities Lending Facility; Term Securities Lending Facility Options Program; and central bank liquidity swaps, including dollar liquidity swap lines and foreign currency liquidity swap lines. The Money Market Investor Funding Facility separately expired on October 30, 2009. In March 2010, the Federal Reserve completed its final planned auction of funds through the Term Auction Facility. 
2. Target federal funds rate and usage of Federal Reserve lending facilities, 2002-10

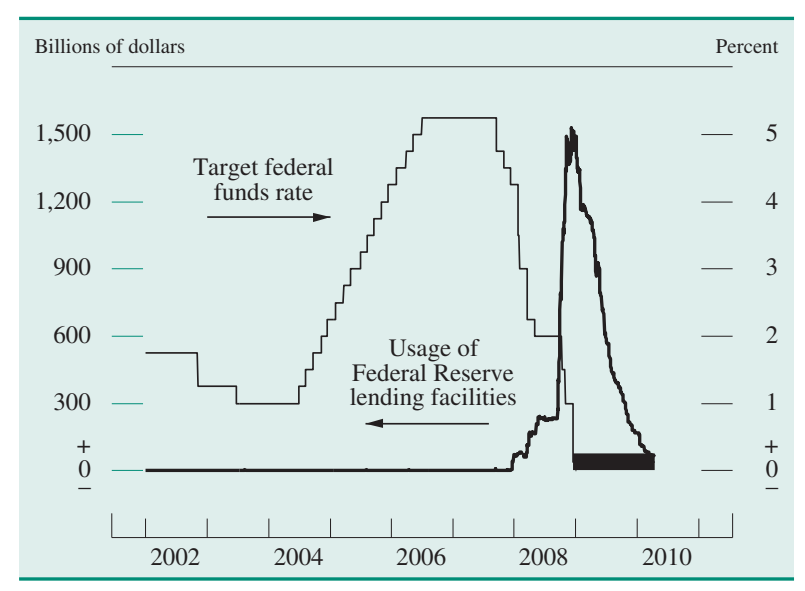

NoTE: The data are daily and extend through April 14, 2010. On December 16, 2008, the Federal Open Market Committee established a target range for the federal funds rate of 0 to $1 / 4$ percent. The black rectangle represents this range. Usage data are the sum of usage amounts for primary, secondary, and seasonal credit; Term Auction Facility; dollar liquidity swaps; Primary Dealer Credit Facility; Commercial Paper Funding Facility; Asset-Backed Commercial Paper Money Market Mutual Fund Liquidity Facility; and Term Asset-Backed Securities Loan Facility.

Source: For federal funds rate, Federal Reserve Board (www. federalreserve.gov/fomc/fundsrate.htm); for usage of lending facilities, Federal Reserve Board, Statistical Release H.4.1, "Factors Affecting Reserve Balances" (www.federalreserve.gov/releases/h41).

in addition to the $\$ 300$ billion of Treasury securities that it purchased between March 2009 and October 2009.

The Treasury provided a large amount of capital to banking institutions under the Troubled Asset Relief Program (TARP), and a substantial volume of that capital was downstreamed by parent holding companies to their commercial bank subsidiaries in the first half of 2009. The Treasury injected capital into financial institutions primarily through the Capital Purchase Program (CPP), under which it acquired shares of preferred stock at the holding company level. In addition, the federal bank regulatory agencies, led by the Federal Reserve, successfully completed the Supervisory Capital Assessment Program (SCAP), which induced several large U.S. banking organizations to raise capital in public equity markets. ${ }^{3}$ Subsequently, a number of other larger banks also raised capital in order to repay their CPP funds and increase the share of common equity in their total capital. Meanwhile, aggregate regulatory capital ratios at the commercial bank level reached historical highs by the end of 2009 .

The government programs to support and assess the level of capital adequacy augmented the highly accommodative monetary and fiscal policies to help

3. For press releases and documents related to the SCAP, see www.federalreserve.gov/bankinginforeg/scap.htm.
3. Indicators for the banking industry, 2001-10

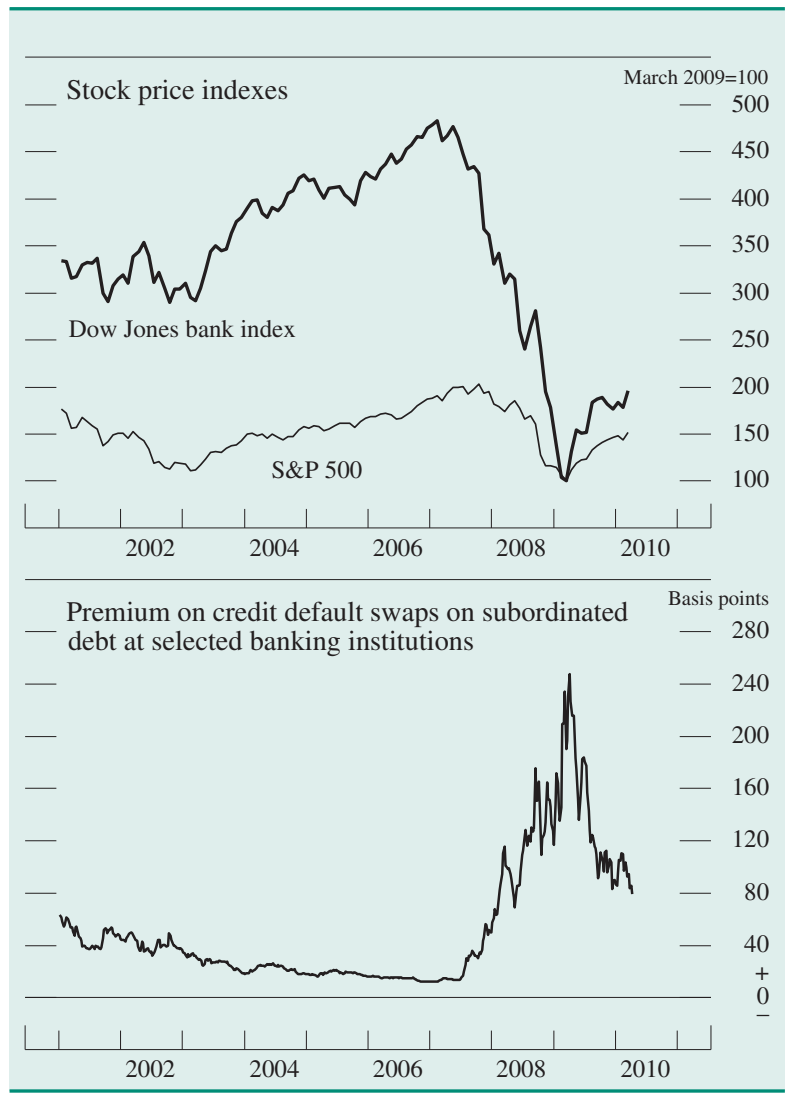

NoTE: The stock price index data are monthly and extend through March 2010. The credit default swap (CDS) data are weekly and extend through April 14, 2010; median spread of all available quotes.

Source: For stock price indexes, Standard \& Poor's and Dow Jones; for premium on CDS, Markit.

improve investors' outlook for the banking industry. The Dow Jones stock price index for banks rebounded sharply beginning in March 2009, as market participants began to mark down the odds of a worsening of the financial crisis, especially after the completion of the SCAP. Indeed, bank stocks have significantly outperformed the broader S\&P 500 index since that time despite historically low profitability, though they remain substantially below their pre-crisis levels (figure 3, top panel). Reflecting the decrease in the perceived risks of failure for large banks after the conclusion of the SCAP, credit default swap spreads on banks' subordinated debt came back to levels last seen in the first half of 2008 (figure 3, bottom panel).

\section{ASSETS}

Severe and widespread economic weakness during 2009 impaired the health of both lenders and borrowers and significantly reduced the supply of and demand for bank loans. Consequently, the total assets of all commercial banks contracted $31 / 2$ percent in 
1. Change in balance sheet items, all U.S. banks, 2000-09

Percent

\begin{tabular}{|c|c|c|c|c|c|c|c|c|c|c|c|}
\hline Item & 2000 & 2001 & 2002 & 2003 & 2004 & 2005 & 2006 & 2007 & 2008 & 2009 & $\begin{array}{c}\text { Mемо } \\
\text { Dec. } \\
2009 \\
\text { (billions } \\
\text { of } \\
\text { dollars) }\end{array}$ \\
\hline Assets . . . . . . . . . . . . & 8.76 & 5.11 & 7.19 & 7.18 & 10.78 & 7.73 & 12.36 & 10.81 & 10.22 & -3.58 & 11,772 \\
\hline Interest-earning assets.... & 8.66 & 3.96 & 7.53 & 7.27 & 11.29 & 7.97 & 12.45 & 10.11 & 8.31 & -2.46 & 10,108 \\
\hline Loans and leases (net) ........ & 9.24 & 1.82 & 5.90 & 6.51 & 11.21 & 10.39 & 11.97 & 10.57 & 2.21 & -5.96 & 6,221 \\
\hline Commercial and industrial. & 8.54 & -6.73 & -7.41 & -4.56 & 4.35 & 12.53 & 11.81 & 20.27 & 3.48 & -18.42 & 1,149 \\
\hline Real estate............... & 10.74 & 7.94 & 14.44 & 9.75 & 15.41 & 13.80 & 14.94 & 7.04 & 4.48 & -.44 & 3,780 \\
\hline Booked in domestic offices......... & 11.02 & 8.02 & 14.85 & 9.66 & 15.09 & 13.93 & 15.05 & 6.77 & 4.75 & -.42 & 3,719 \\
\hline One- to four-family residential & 9.28 & $\begin{array}{l}0.02 \\
5.70\end{array}$ & 19.86 & 10.01 & 15.75 & 11.95 & 15.11 & 5.53 & 3.07 & 3.17 & 2,121 \\
\hline Other $\mathrm{r}$ & 13.31 & 10.95 & 8.81 & 9.19 & 14.20 & 16.61 & 14.96 & 8.39 & 6.89 & $\begin{aligned} 5.11 \\
-4.82\end{aligned}$ & 1,597 \\
\hline Booked in foreign offices & -1.62 & 3.97 & -7.41 & 15.74 & 35.59 & 7.19 & 8.79 & 22.76 & -9.28 & -1.72 & 62 \\
\hline Consumer ................. & 8.04 & 4.16 & 6.55 & 9.31 & 10.16 & 2.30 & 6.19 & 11.67 & 4.23 & -1.95 & 969 \\
\hline Other loans and leases $\ldots \ldots \ldots \ldots \ldots \ldots$ & 7.01 & -2.02 & -.03 & 8.31 & 3.57 & -.18 & 3.17 & 13.01 & -6.41 & -7.32 & 537 \\
\hline Loan loss reserves and unearned income & 7.98 & 13.15 & 5.73 & -3.41 & -3.72 & -5.55 & 1.69 & 27.98 & 75.28 & 35.73 & 214 \\
\hline 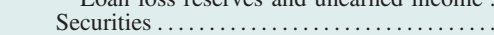 & 6.36 & 7.22 & 16.20 & 9.44 & 10.58 & 2.40 & 11.53 & 4.54 & -.53 & 21.24 & 2,646 \\
\hline Investment account. & 2.85 & 8.88 & 13.53 & 8.70 & 6.15 & 1.19 & 6.94 & -4.4 & 10.07 & 26.66 & 2,177 \\
\hline $\begin{array}{r}\text { U.S. Treasury ............. } \\
\text { U. }\end{array}$ & -32.72 & -40.27 & 41.92 & 14.14 & -15.87 & -17.59 & -19.30 & -26.93 & 7.96 & 215.48 & 100 \\
\hline $\begin{array}{l}\text { U.S. government agency } \\
\text { and corporation obli }\end{array}$ & & 12.84 & 1809 & & & & & & & & \\
\hline Other .... & $\begin{array}{r}3.13 \\
13.39\end{array}$ & 12.18 & $\begin{array}{r}18.09 \\
2.72\end{array}$ & $\begin{array}{l}9.68 \\
5.98\end{array}$ & $\begin{array}{l}9.46 \\
3.02\end{array}$ & $\begin{array}{l}-1.83 \\
10.12\end{array}$ & $\begin{array}{r}4.71 \\
13.78\end{array}$ & $\begin{array}{r}-12.15 \\
10.75\end{array}$ & $\begin{array}{r}15.44 \\
2.66\end{array}$ & $\begin{array}{l}15.49 \\
35.05\end{array}-1$ & $\begin{array}{r}1,190 \\
887\end{array}$ \\
\hline Trading account. & 37.16 & -3.72 & 36.12 & 14.01 & 36.8 & 7.96 & 31.3 & 35. & -26.69 & 1.17 & $\begin{array}{l}001 \\
469\end{array}$ \\
\hline Other........... & 10.30 & 13.09 & $\begin{array}{l}0.12 \\
-2.93\end{array}$ & $\begin{array}{r}1.01 \\
6.76\end{array}$ & $\begin{array}{l}30.8 \\
14.2\end{array}$ & 5.81 & 19.31 & 22. & $\begin{array}{r}-20.09 \\
73.68\end{array}$ & -20.71 & $\begin{array}{r}409 \\
1,241\end{array}$ \\
\hline Noninterest-earning assets. & 9.45 & 12.74 & 5.11 & 6.64 & 7.61 & 6.19 & 11.79 & 15.42 & 22.30 & -9.89 & 1,664 \\
\hline Liabilities ............... & 8.59 & 4.45 & 7.13 & 7.24 & 9.56 & 7.74 & 12.10 & 10.79 & 11.27 & -5.46 & 10,458 \\
\hline Core depos & 7.53 & 10.55 & 7.58 & 7.29 & 8.25 & 6.40 & & & 14.51 & 8.07 & 5,843 \\
\hline denos & -1.31 & 10.20 & -5.12 & 2.82 & 3.2 & -1.18 & -4. & -1.22 & 20.72 & 6.34 & 892 \\
\hline ncluding MMDAs) & 12.51 & 20.68 & 18.46 & 13.71 & 11.72 & $\begin{array}{r}-1.10 \\
6.93\end{array}$ & 5.53 & 3.34 & 9.98 & $\begin{array}{r}0.74 \\
17.78\end{array}$ & 3,879 \\
\hline & 7.20 & -7.23 & -4.92 & -6.79 & 1.58 & 12.88 & 16.97 & 18.03 & 23.48 & -15.88 & 1,072 \\
\hline Mana & 8.79 & -2.73 & 5.34 & $\begin{array}{r}-0.19 \\
6.96\end{array}$ & 12.06 & 12.24 & 19.45 & 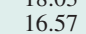 & $\begin{array}{r}25.40 \\
6.45\end{array}$ & -16.61 & 4,038 \\
\hline 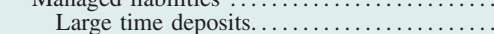 & 19.37 & -3.65 & 5.05 & 1.42 & 21.86 & 22.88 & 15. & 1. & 4.56 & -16.15 & 897 \\
\hline $\mathrm{D}$ & 7.84 & -10.96 & 4. & 12. & 16. & 6.32 & & 25. & 2.4 & -.60 & 1,529 \\
\hline & 13.98 & 9.56 & -.59 & 5.08 & 10.4 & 11.41 & 22.60 & 16.8 & 4.60 & -15.53 & 154 \\
\hline Gross federal funds purchase & 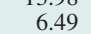 & 5.72 & 12.75 & -8.70 & 8.40 & 15.62 & 9.47 & 7.06 & 5.76 & -31.70 & 537 \\
\hline Other managed liabilities ................... & $\begin{array}{l}0.49 \\
1.80\end{array}$ & -.28 & .97 & 22.00 & 1.37 & $\begin{array}{r}13.02 \\
6.15\end{array}$ & $\begin{array}{r}9.47 \\
18.89\end{array}$ & 28.44 & $\begin{array}{r}5.10 \\
14.38\end{array}$ & -27.25 & 921 \\
\hline Revaluation losses held in trading accounts & 7.47 & -17.06 & 33.44 & 14.03 & -12.61 & -17.86 & 6.89 & 42.66 & 88.60 & -57.17 & 166 \\
\hline Other $\ldots \ldots \ldots \ldots \ldots \ldots \ldots \ldots \ldots$ & 20.61 & 14.90 & 5.23 & 5.28 & 17.19 & -1.60 & 22.33 & 3.21 & -8.63 & -3.31 & 410 \\
\hline Capital account $\ldots \ldots \ldots \ldots \ldots$ & 10.65 & 12.29 & 7.84 & 6.61 & 23.14 & 7.59 & 14.69 & 10.94 & .96 & 14.54 & 1,314 \\
\hline & & & & & & & & & & & \\
\hline Comm & 12.16 & 13.10 & 6.82 & 8.99 & 13.93 & 16.87 & 14.91 & 9.21 & 6.74 & -5.69 & 1,588 \\
\hline & 3.29 & 29.05 & 15.54 & 10.12 & 13.4 & 2.06 & 10.22 & -1.2 & 11.37 & 11.54 & 1,192 \\
\hline Federal Home Loan Bank advances. & n.a. & $\begin{array}{l}\text { n.a. } \\
\text { n.0. }\end{array}$ & $\begin{array}{l}17.21 \\
\end{array}$ & 3.71 & 3.73 & $\begin{array}{r}10.00 \\
\end{array}$ & 29.80 & 30.62 & 17.51 & -24.87 & 402 \\
\hline
\end{tabular}

Note: Data are from year-end to year-end and are as of March 23, 2010.

1. Measured as the sum of large time deposits in domestic offices, deposits booked in foreign offices, subordinated notes and debentures, federal funds purchased and securities sold under repurchase agreements, Federal Home Loan Bank advances, and other borrowed money.

2. Measured as the sum of construction and land development loans secured by real estate; real estate loans secured by nonfarm nonresidential properties or

2009, the first annual contraction since 1948 (table 1 and figure 4). However, the decline in banks' assets last year was even larger-about $51 / 4$ percent-after accounting for the acquisition of several nonbanks by commercial banks (see box "Adjustments to the Balance Sheet Data for Structure Activity in 2009"). The share of industry assets in the top 100 banks fell slightly, the first annual decline since 1991 (see box "Bank Failures and Measures of Banking Concentration in 2009").

The decline in assets on banks' books reflected in large part a fall in gross loans of about 5 percent, or 7 percent when adjusted for structure activity. Relative to 2008, on an adjusted basis, loan declines in 2009 spread from closed-end residential real estate loans to all major loan classes, as the economic contraction encompassed the consumer, business, and by multifamily residential properties; and loans to finance commercial real estate, construction, and land development activities not secured by real estate. n.a. Not available.

MMDA Money market deposit account

RP Repurchase agreement.

\section{Composition of assets at commercial banks, 2006-09}

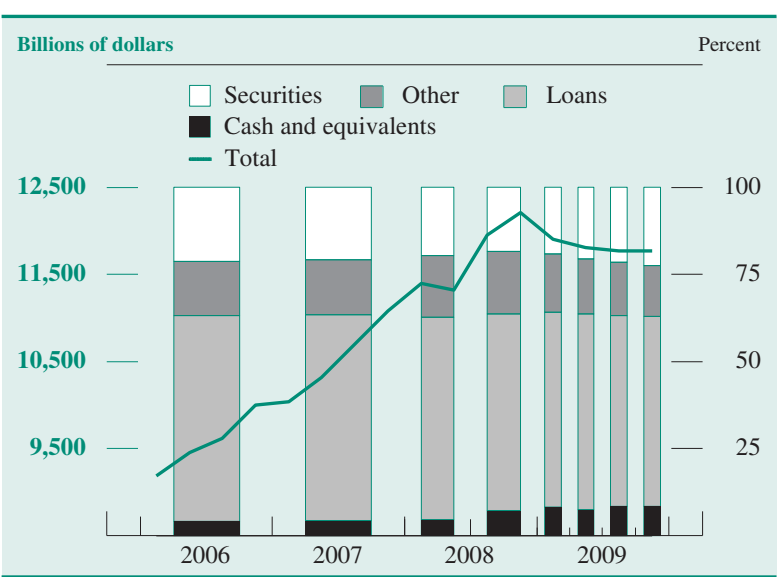

NOTE: Other assets consist of loans to banks, trading assets (excluding securities), and other assets not elsewhere classified. 


\section{Adjustments to the Balance Sheet Data for Structure Activity in 2009}

One consequence of the turmoil in financial markets over the past two years has been a steady stream of acquisitions and reorganizations by major financial institutions. Several large thrift institutions that were acquired by bank holding companies in 2008 were consolidated into the commercial bank subsidiaries of those institutions during 2009 , boosting assets on banks' books. ${ }^{1}$ In addition to these bank-nonbank structure events, a large credit card bank completed balance sheet consolidation of its securitized assets in the fourth quarter of 2009 under the new accounting requirements established by Statements of Financial Accounting Standards Nos. 166 and 167; similar events will boost assets on many banks' books in the first quarter of 2010.

In general, the effects of these structure activities on bank balance sheet data do not reflect net asset creation or elimination. To better capture net asset changes, the data shown in table A have been adjusted to remove the effects on the data series that have resulted from these structure events. The growth rates of selected balance sheet components given in the table have been adjusted to remove the estimated effects of the following events that occurred over 2009, as well as the five major structure events that were detailed in the Federal Reserve Bulletin article about the 2008 developments: ${ }^{2}$

- Bank of America, N.A., consolidated the assets and liabilities of Countrywide Bank, F.S.B., on April 27, 2009 , boosting industry assets by about $\$ 115$ billion.

1. In publishing its H.8 statistical release, "Assets and Liabilities of Commercial Banks in the United States," each week, the Federal Reserve describes nonbank structure activity that affects bank assets by $\$ 5.0$ billion or more. For a list of such activity dating to December 16,2005 , see the H.8 "Notes on the Data" webpage (www.federalreserve.gov/releases $/ \mathrm{h} 8 /$ h8notes.htm). In addition, information about structure activity involving any banking organization is available in the Federal Financial Institutions Examination Council's central repository of data, the National Information Center (www.ffiec.gov/nicpubweb/nicweb/nichome.aspx).

2. See box "Adjustments to the Balance Sheet Data for Structure Activity" in Morten L. Bech and Tara Rice (2009), "Profits and Balance Sheet Developments at U.S. Commercial Banks in 2008," Federal Reserve Bul-
- Commercial bank subsidiaries of Wells Fargo \& Company consolidated the assets and liabilities of Wachovia Mortgage, F.S.B., and Wachovia Bank, F.S.B., on November 1, 2009, boosting industry assets by about $\$ 85$ billion.

- Bank of America, N.A., consolidated the assets and liabilities of Merrill Lynch Bank and Trust Co., F.S.B., on November 2, 2009, boosting industry assets by about $\$ 40$ billion.

- A large credit card bank consolidated securitized credit card loans onto its balance sheet as of the December 2009 Consolidated Reports of Condition and Income (Call Report), boosting industry assets by about $\$ 25$ billion. ${ }^{3}$

These four events resulted in the net addition of more than $\$ 265$ billion of nonbank assets to commercial banks' balance sheets last year, bringing the total since 2006 to nine major events and $\$ 847$ billion. As a consequence, the adjusted growth rates shown in table A are generally lower than the unadjusted growth rates shown in table 1 of the main text. Notably, after accounting for the consolidation of assets from Countrywide and Wachovia, the growth of residential real estate loans in the second and fourth quarters was markedly lower, more clearly reflecting the weakness in most residential real estate markets over that period. Overall, the adjusted data on growth in total loans show that, after adjusting for major structure events, bank lending steadily contracted in each quarter of 2009.

letin, vol. 95 (June), pp. A62-A63, www.federalreserve.gov/pubs/bulletin/ 2009/pdf/bankprofits09 pdf. The structure-adjusted growth rates shown in the table were generally based on the difference between the end-of-period reported data and the beginning-of-period data adjusted for the structure event. To adjust for Bank of America, N.A., in 2009:Q2 and 2009:Q4, and the bank subsidiaries of Wells Fargo \& Company in 2009:Q4, the beginning-of-period values were determined by adding the value of the assets of the acquired thrift(s) to the reported data for the previous quarter. Similarly, to adjust for the large credit card bank in 2009:Q4, the beginning-of-period values were determined by adding the value of the securitized loans to the reported data for the previous quarter.

3. See note 11 of the main text.

A. Structure-adjusted change in selected balance sheet items, all U.S. banks, 2007-09

Percent, annual rate

\begin{tabular}{|c|c|c|c|c|c|c|c|c|c|c|c|}
\hline \multirow{2}{*}{$\begin{array}{l}\text { Balance sheet } \\
\text { category }\end{array}$} & \multicolumn{4}{|c|}{2008} & \multicolumn{4}{|c|}{2009} & \multirow{2}{*}{2007} & \multirow{2}{*}{2008} & \multirow{2}{*}{2009} \\
\hline & Q1 & Q2 & Q3 & Q4 & Q1 & Q2 & Q3 & Q4 & & & \\
\hline Assets $\ldots \ldots \ldots \ldots \ldots \ldots$ & 12.38 & -1.21 & 8.92 & 3.51 & -8.49 & -5.64 & -3.56 & -3.51 & 11.38 & 6.10 & -5.15 \\
\hline Loans and leases (gross) $\ldots$ & 5.05 & -.70 & .40 & -6.64 & -4.08 & -6.27 & -11.73 & -6.49 & 11.39 & -.43 & -6.93 \\
\hline Commercial and industrial & 9.49 & 2.19 & 7.14 & -6.19 & -16.32 & -18.47 & -25.44 & -20.34 & 20.28 & 3.23 & -18.62 \\
\hline Consumer $\ldots \ldots \ldots \ldots \ldots$ & 9.27 & 7.76 & -.23 & -4.18 & -3.21 & -2.39 & -5.55 & -6.19 & 11.67 & 3.10 & -4.35 \\
\hline One- to four-family residential & -4.36 & -10.36 & -4.10 & -4.90 & 2.05 & -5.01 & -9.56 & 5.29 & 7.30 & -5.83 & -1.78 \\
\hline Commercial real estate loans ${ }^{1}$. & 5.95 & 4.97 & 4.17 & .61 & -.41 & -4.37 & -7.83 & -11.79 & 9.17 & 3.98 & -5.97 \\
\hline Other loans and leases ........ & 9.29 & 1.86 & 10.60 & -10.49 & -3.00 & -2.34 & -5.77 & -10.74 & 10.06 & 2.77 & -5.37 \\
\hline Securities............. & .30 & -3.33 & 13.36 & -19.15 & 11.97 & 24.18 & 22.81 & 16.17 & 5.31 & -2.49 & 19.98 \\
\hline Mortgage-backed securities & 10.74 & 11.50 & 2.44 & 12.60 & 2.59 & 13.17 & 12.67 & 12.06 & .43 & 9.39 & 10.51 \\
\hline Liabilities .................. & 13.30 & -1.20 & 10.88 & 4.26 & -11.61 & -7.17 & -5.11 & -4.25 & 11.41 & 7.07 & -6.81 \\
\hline Capital account . & 4.33 & .46 & -7.44 & -5.59 & 21.94 & 10.11 & 9.25 & 8.06 & 11.16 & -2.07 & 12.88 \\
\hline Мемо & & & & & & & & & & & \\
\hline Unused loan commitments & .21 & -5.88 & -16.43 & -31.87 & -29.30 & -24.90 & -16.08 & -8.94 & 9.50 & -12.98 & -18.46 \\
\hline Federal Home Loan Bank advances & 15.96 & 5.22 & 52.64 & -50.30 & -49.47 & -43.31 & -43.92 & -22.20 & 35.61 & 4.83 & -34.07 \\
\hline
\end{tabular}

Note: Data are from period-end to period-end and are as of April 15, 2010, for both commercial banks and thrift institutions. For a discussion of the structure adjustments, see the box text; for an explanation of the adjustment calculation, see note 2 of the box text.

1. Measured as the sum of construction and land development loans secured by real estate; real estate loans secured by nonfarm nonresidential properties or by multifamily residential properties; and loans to finance commercial real estate, construction, and land development activities not secured by real estate.

Source: Federal Financial Institutions Examination Council, Consolidated Reports of Condition and Income (Call Report) for commercial banks and thrift institutions; staff calculations. 


\section{Bank Failures and Measures of Banking Concentration in 2009}

Among the major developments in the commercial banking sector in 2009 were the failure of 120 banks with $\$ 117.9$ billion in assets (figure A). Since the middle of 2007, the health of the commercial banking sector has been adversely affected by the economic downturn and disruptions to financial markets caused by the financial crisis. The number of problem institutions, as identified by the Federal Deposit Insurance Corporation (FDIC), increased greatly throughout 2009 and reached about 700 institutions by year-end, up from about 250 a year earlier. ${ }^{1}$

The FDIC sold most of the $\$ 117.9$ billion in assets at the 120 failed banks to other surviving banks. However, given the uncertain quality of some of the seized assets, in many instances the FDIC entered loss-sharing agreements with the purchasers of disposed assets, and in some cases it retained assets for future liquidation.

Very few new commercial banks were chartered during 2009. Merger activity among commercial banks slowed a bit again, and roughly two-fifths of all mergers involved a failed bank. Together, these structural developments caused the number of banks to continue declining over the year, to about 6,900 at year-end 2009 from about 7,100 at year-end 2008 (figure B, top panel).

Concentration in the banking industry was little changed over 2009 after many years of steady increases.

1. This total includes depository institutions insured by the FDIC that are not commercial banks. See Federal Deposit Insurance Corporation (2009), Quarterly Banking Profile (Washington: FDIC, December 31), available at www2.fdic.gov/QBP/qbpSelect.asp?menuItem=QBP

A. Assets at failed commercial banks, 2008-10

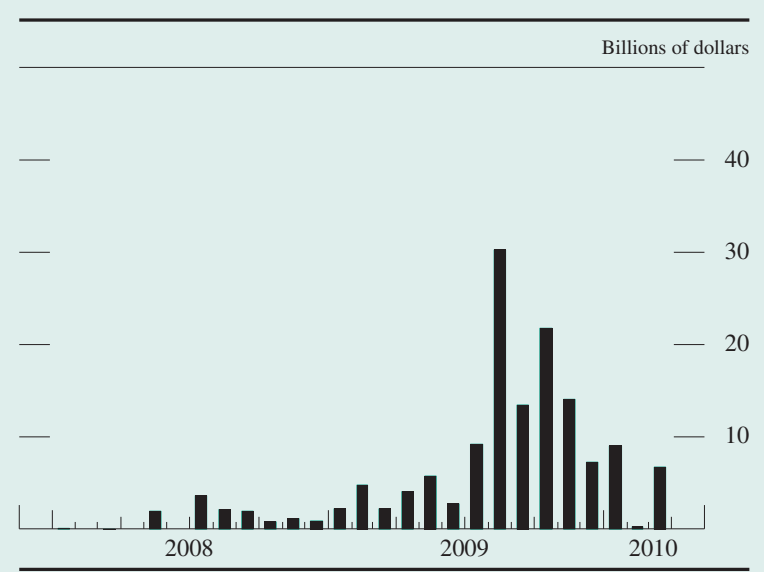

Note: The data are monthly and extend through March 2010. Assets are as of the fail date.

SouRCE: Federal Deposit Insurance Corporation via SNL Financial.
The share of assets held by the 10 largest banks increased only slightly, to just under $54 \frac{1}{2}$ percent at the end of 2009 , even with the consolidation of assets from acquired thrifts onto the balance sheets of the largest banks (figure $\mathrm{B}$, bottom panel). The share of assets held by the top 100 banks declined a bit over the year to $81 \frac{1}{2} 2$ percent, the first annual decline since 1991.

The number of bank holding companies (BHCs) fell at about the same pace as in recent years to about 5,000 at the end of 2009 (for multitiered BHCs, only the top-tier organization is counted in these figures). While merger activity among BHCs slowed compared with the past two years, the number of newly formed BHCs decreased for the second consecutive year, and a number of BHCs exited because of the failures of their subsidiary banks. The number of financial holding companies also declined slightly, mainly as a result of mergers and decertifications of financial holding company status. ${ }^{2}$

2. Statistics on financial holding companies include both domestic BHCs that have elected to become financial holding companies and foreign banking organizations operating in the United States as financial holding companies and subject to the Bank Holding Company Act. For more information, see Board of Governors of the Federal Reserve System and U.S. Department of the Treasury (2003), Report to the Congress on Financial Holding Companies under the Gramm-Leach-Bliley Act (Washington: Board of Governors and Department of the Treasury, November), available at www.federalreserve.gov/pubs/reports_other.htm.

B. Number of banks, and share of assets at the largest banks, 1990-2009

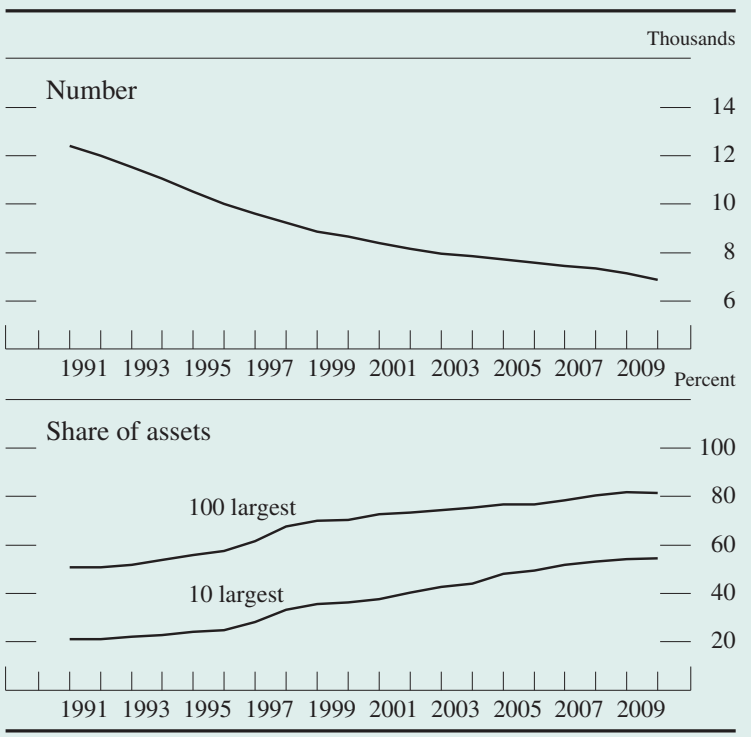

NotE: The data are as of year-end. For the definition of bank size, see the general note on the first page of the main text. 
real estate sectors. The runoff in loans involved a number of related factors. With less need for external financing and the uncertain economic outlook, demand from businesses for bank-intermediated credit declined broadly. Household loan demand similarly dropped as consumers began deleveraging their balance sheets, in part to adjust to the declines in the values of their homes and equity holdings. Weak balance sheets of both businesses and households likely also reduced the number of creditworthy borrowers. In addition, banks tightened their lending policies substantially over 2008 and 2009, partly in response to a less favorable or more uncertain economic outlook. Reportedly, banks were also responding to a range of other factors, including the poor quality of assets on their balance sheets, the adverse implications of that situation for their own capital, and disruptions in securitization markets.

The credit quality of existing loans in all major classes continued to deteriorate significantly, on balance, over the year, resulting in historically high charge-off rates. Banks' overall loan delinquency rate (that is, the proportion of loans whose payments are 30 days or more past due or not accruing interest) rose to $71 / 4$ percent at year-end, the highest level posted since at least 1985 . Credit quality deteriorated most sharply for real estate loans. For 2009 as a whole, banks cumulatively charged off $2 \frac{1}{2}$ percent of the loans that were outstanding at year-end 2008, directly contributing to the decline in loans outstanding.

In contrast to the drop in loans, banks' holdings of securities expanded about 20 percent over 2009 (adjusted for structure activity), with growth particularly strong in holdings of Treasury securities and agency debt securities (excluding MBS). In addition, as the Federal Reserve ramped up its purchases of Treasury and agency securities over the course of the year, reserve balances grew as a share of banks' total assets. Indeed, at the end of 2009, such balances accounted for 5 percent of banks' total assets; reserve balances had accounted for just $1 / 4$ percent of assets before the financial turmoil of the fall of 2008 .

\section{Business Loans}

Commercial and industrial (C\&I) loans on banks' books plummeted $18 \frac{1}{2}$ percent in 2009 , the steepest annual decline since at least 1985, and the pace of contraction gained momentum over the year (figure 5).

Demand for C\&I loans decreased as nonfinancial firms' need for external finance dropped off. The financing gap at nonfinancial corporations-the dif-
5. Change in commercial and industrial loans, 1986-2009

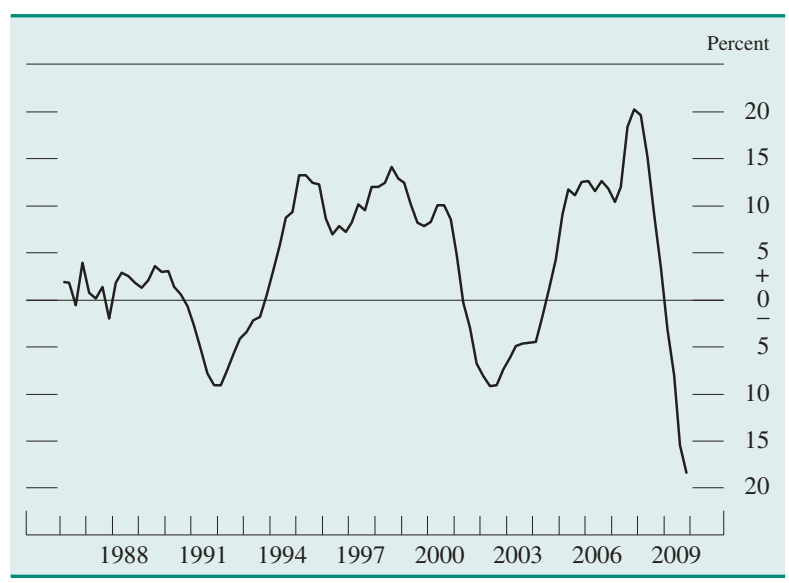

Note: The data are quarterly; changes are from four quarters earlier.

ference between capital expenditures and internally generated funds-fell sharply in the second half of 2009 and ended the year below zero (figure 6). Anecdotal reports associated with the weekly data collected by the Federal Reserve indicate that originations of large loans were sparse last year, and there were broad-based paydowns of existing C\&I loans across banks and industries. The contraction in C\&I loans was especially steep at large banks last year, which is consistent with reports that some large firms with access to capital markets paid down bank loans with the proceeds of bond issues. Indeed, bond issuance was robust after the first quarter amid increasingly attractive conditions in the corporate

6. Financing gap and net equity retirement at nonfarm nonfinancial corporations, 1990-2009

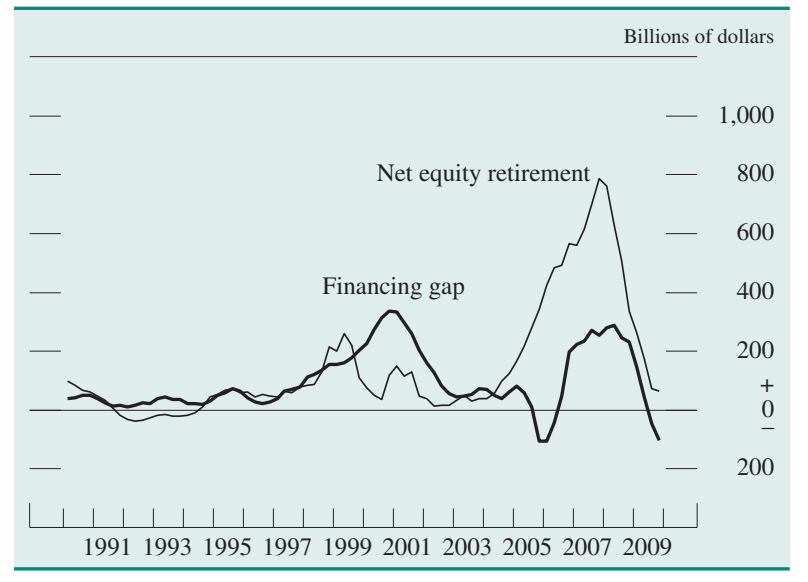

NotE: The data are four-quarter moving averages. The financing gap is the difference between capital expenditures and internally generated funds. Net equity retirement consists of funds used to repurchase equity less funds raised in equity markets.

SourCE: Federal Reserve Board, Statistical Release Z.1, "Flow of Funds Accounts of the United States," table F.102 (www.federalreserve.gov/ releases/z1). 
7. Selected components of net financing for nonfinancial businesses, 2005-09

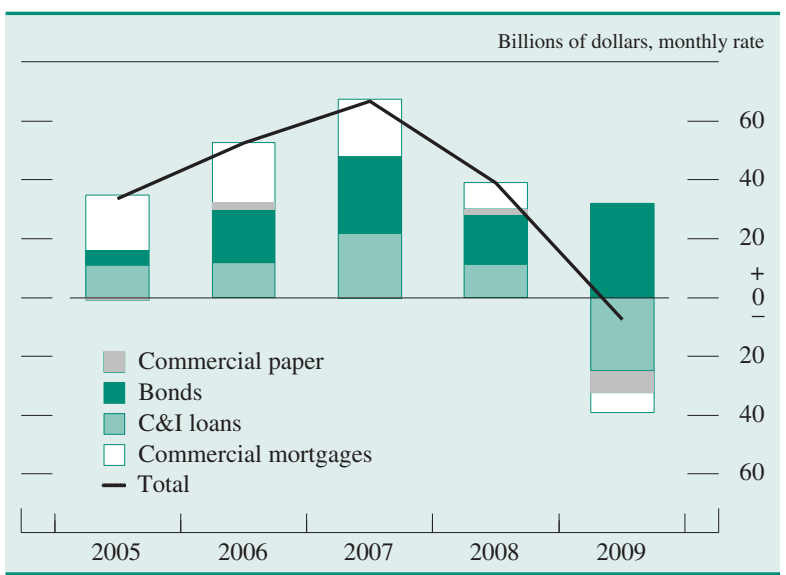

Note: C\&I is commercial and industrial.

Source: Federal Reserve Board, Statistical Release Z.1, "Flow of Funds Accounts of the United States" (www.federalreserve.gov/releases/z1).

bond market (figure 7). Overall, according to domestic banks responding to the Federal Reserve's Senior Loan Officer Opinion Survey on Bank Lending Practices (SLOOS), the most important factors explaining the decline in C\&I loans last year were lower loan demand from creditworthy borrowers and a deterioration in the credit quality of potential borrowers.

On the supply side, results from the SLOOS indicated that unprecedented fractions of banks tightened standards and a wide range of terms on C\&I loans through the first half of 2009 (figure 8). Results from the Federal Reserve's quarterly Survey of Terms of Business Lending also pointed to a tightening in credit conditions, indicating that the spreads of C\&I loan rates over banks' cost of funds increased sharply last year. Even after adjusting for changes in the riskiness of loans and other nonprice loan characteristics, significant increases in C\&I loan rate spreads were reported on loans of all sizes and on loans originated by both large and small banks.

A number of developments contributed importantly to last year's decline in C\&I loans. As financial market conditions improved in 2009, the drop in C\&I loans may have been exacerbated by repayments of draws on existing credit lines; firms had reportedly drawn heavily on these lines for precautionary liquidity during the extreme disruptions in credit markets in the fall of 2008. In addition, strained conditions in the syndicated loan market may also have contributed to the sharp decline in C\&I loans at large banks, as banks, to complete syndicated deals, had relied heavily on some types of structured vehicles that have not regained acceptance by investors. In the leveraged
8. Changes in demand and supply conditions at selected banks for commercial and industrial loans to large and middle-market firms, 1990-2009

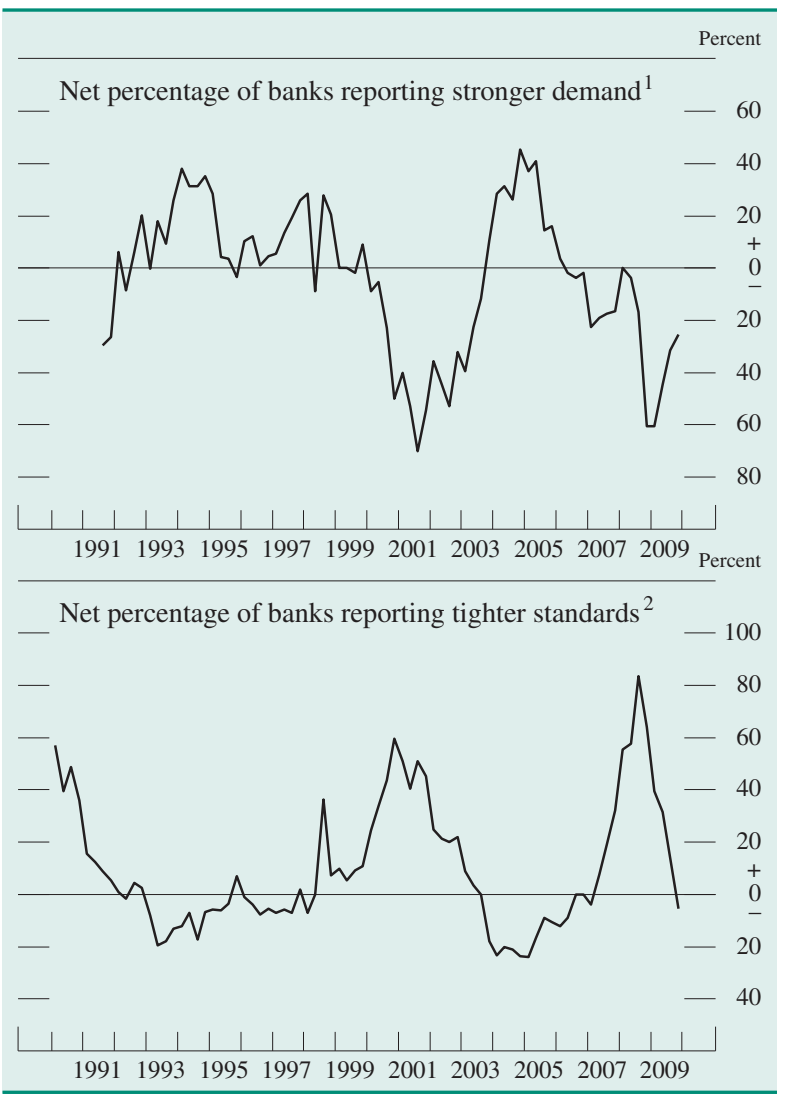

Note: The data are drawn from a survey generally conducted four times per year; the last observation is from the January 2010 survey, which covers 2009:Q4. Net percentage is the percentage of banks reporting an increase in demand or a tightening of standards less, in each case, the percentage reporting the opposite. The definition for firm size suggested for, and generally used by, survey respondents is that large and middle-market firms have annual sales of $\$ 50$ million or more.

1. Series begins with the November 1991 survey.

2. Series begins with the May 1990 survey.

Source: Federal Reserve Board, Senior Loan Officer Opinion Survey on Bank Lending Practices (www.federalreserve.gov/boarddocs/snloansurvey).

segment of the C\&I loan market, issuance was weak through most of last year despite consistent improvement in loan prices and trading liquidity in the secondary market for such loans. In the fourth quarter, however, issuance of syndicated leveraged loans picked up somewhat, and the terms on such loans reportedly eased a bit.

Policymakers have expressed concern about the difficulties that creditworthy business borrowers without access to capital markets-typically small businesses-are experiencing in obtaining credit in the current lending environment. Gauging the degree to which small businesses' access to credit has tightened is difficult, as only sparse and imperfect measures of small business lending by banks are avail- 
able. ${ }^{4}$ A survey by the National Federation of Independent Business found that slightly larger net fractions of small businesses in 2009 reported that they faced tightening credit conditions than had so reported during the period of banking strains in the early 1990s, and that approval rates for business owners attempting to borrow were significantly lower than in the mid-2000s. That said, only 8 percent of surveyed business owners indicated that access to credit was their principal economic problem, with slow sales and an uncertain economic situation being more commonly cited. ${ }^{5}$ In part, the tight credit conditions reported by small businesses may reflect the reduced credit quality of such firms. Banks reported in the SLOOS that delinquency rates in the fourth quarter were higher for C\&I loans to small businesses than for such loans to larger businesses, and more banks expected improvement over 2010 in the credit quality of C\&I loans to larger firms than of C\&I loans to smaller firms.

Federal and state regulators issued guidance in February 2010 stating that banks should strive to make prudent loans to creditworthy small businesses, and the regulators directed examiners to conduct their reviews in a way that would not discourage such activities. ${ }^{6}$ In addition, the availability of loans to small businesses was supported by the Term AssetBacked Securities Loan Facility, which helped revitalize the market for securities guaranteed by the Small Business Administration.

Delinquency and charge-off rates on C\&I loans increased through 2009, and while these rates were not as high as those in other loan categories, their levels at year-end were roughly comparable with those from the early 1990s (figure 9). Most SLOOS respondents indicated that they expected the credit

4. For example, each year the second-quarter Call Report records the amount of C\&I loans outstanding that were made originally in small amounts; these amounts are often used as a proxy for small business lending but also may capture other lending, such as business credit card loans and loans to large firms that were issued by multiple banks. In addition, realized flows of credit generally reflect both demand and supply conditions, and so a fall in loans may not necessarily be due to supply factors. With those caveats, small C\&I loans at banks declined about $4 \frac{1}{2}$ percent from the second quarter of 2008 to the second quarter of 2009, while all other C\&I loans declined about 9 percent.

5. William J. Dennis, Jr. (2010), Small Business Credit in a Deep Recession (Washington: NFIB Research Foundation, February).

6. See Interagency Statement on Meeting the Credit Needs of Creditworthy Small Business Borrowers, an attachment to Board of Governors of the Federal Reserve System, Federal Deposit Insurance Corporation, National Credit Union Administration, Office of the Comptroller of the Currency, Office of Thrift Supervision, and Conference of State Bank Supervisors (2010), "Regulators Issue Statement on Lending to Creditworthy Small Businesses," joint press release, February 5, www.federalreserve.gov/newsevents/press/bcreg/ 20100205a.htm.
9. Delinquency and charge-off rates for loans to businesses, by type of loan, 1990-2009

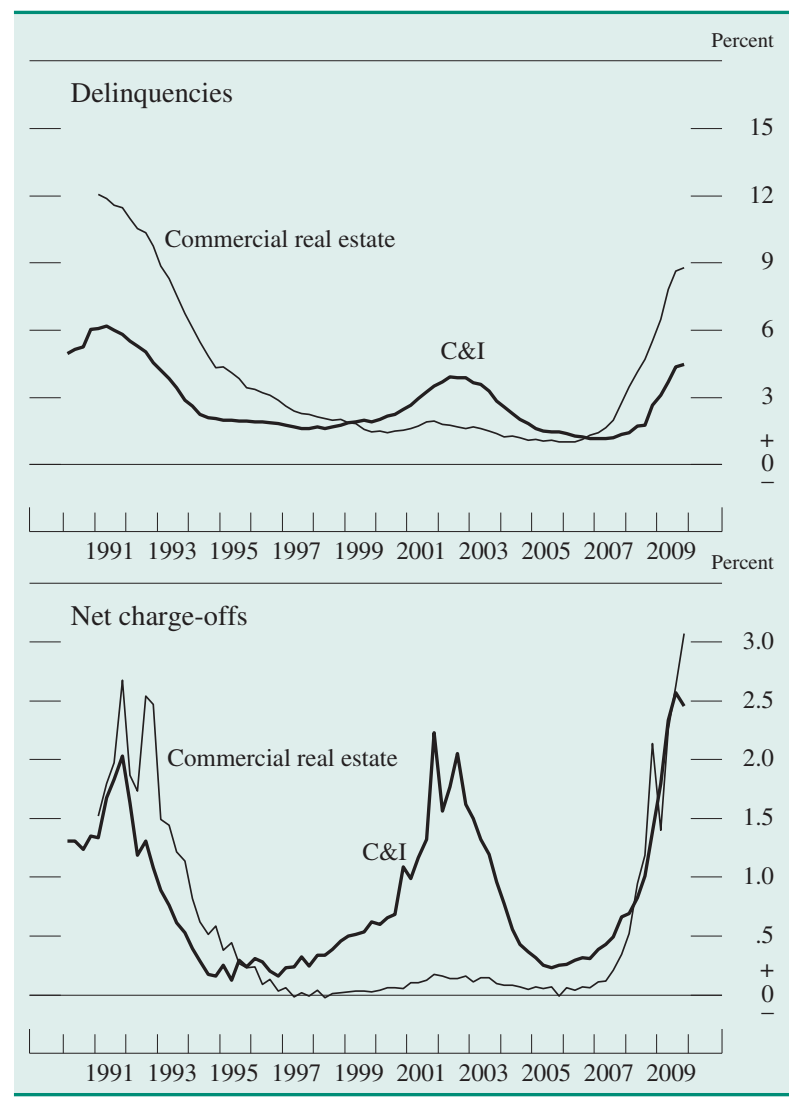

NotE: The data are quarterly and seasonally adjusted; the data for commercial real estate begin in 1991. Delinquent loans are loans that are not accruing interest and those that are accruing interest but are more than 30 days past due. The delinquency rate is the end-of-period level of delinquent loans divided by the end-of-period level of outstanding loans. The net charge-off rate is the annualized amount of charge-offs over the period, net of recoveries, divided by the average level of outstanding loans over the period. For the computation of these rates, commercial real estate loans exclude loans not secured by real estate (see table 1 , note 2). C\&I is commercial and industrial.

quality of C\&I loans to stabilize or improve in 2010, although banks' outlook regarding credit quality was more sanguine for loans to larger businesses than for loans to smaller businesses. In addition, some signs of stabilization in C\&I loan quality were apparent in the fourth quarter of 2009, as the delinquency rate on C\&I loans increased only slightly further and the charge-off rate declined a bit.

The fundamentals of CRE were poor in 2009, with prices of commercial properties dropping, rents declining, and vacancy rates rising. Financing conditions for CRE were strained over the year: Almost no issuance of commercial mortgage-backed securities occurred (figure 10), and large net fractions of banks reported tighter standards for CRE loans in the SLOOS (figure 11). The pace of the runoff in CRE loans increased over the year, while delinquency and 
10. Gross issuance of selected mortgage- and asset-backed securities, 2003-09

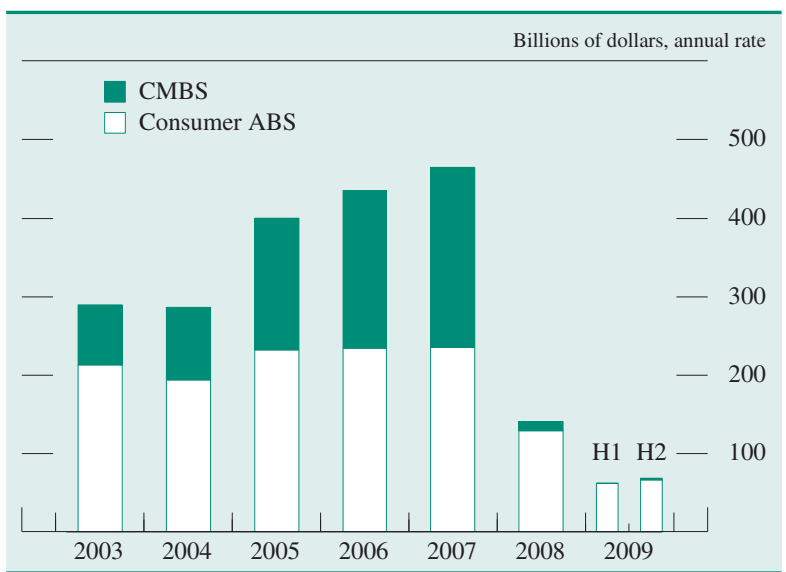

Note: CMBS are commercial mortgage-backed securities; consumer ABS (asset-backed securities) are securities backed by credit card loans, nonrevolving consumer loans, and auto loans.

SouRCE: For CMBS, Commercial Mortgage Alert; for ABS, Inside MBS \& $A B S$ and Merrill Lynch.

11. Changes in demand and supply conditions at selected banks for commercial real estate loans, 1996-2009

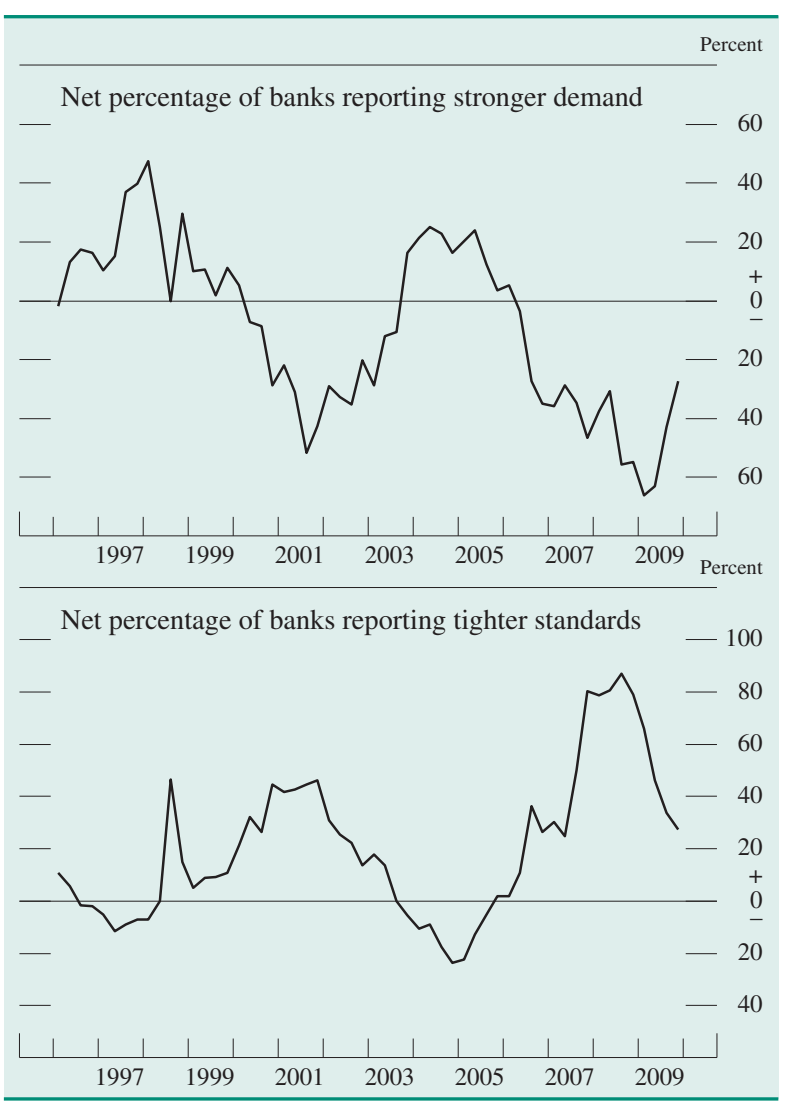

NoTE: See figure 8 , general note and source note.
12. Delinquency and charge-off rates for construction and land development loans, by type of loan, 2007-09

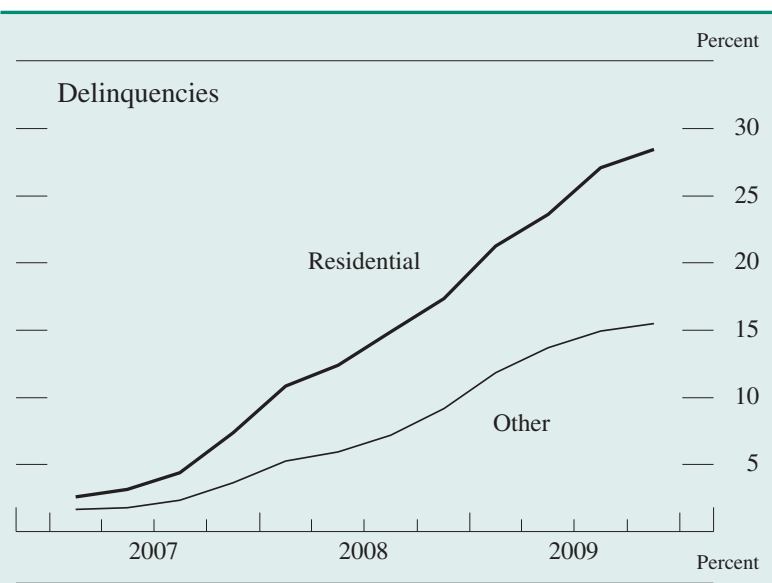

Net charge-offs

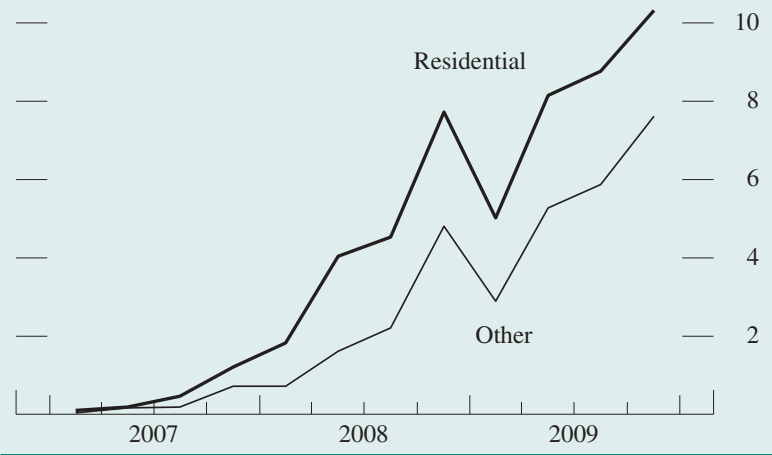

NOTE: The data are quarterly and are available since the series began in 2007:Q1. For definitions of delinquencies and net charge-offs, see the note for figure 9. Other consists of other construction loans and all other land development and other land loans.

charge-off rates reached historically high levels. In particular, the delinquency rate on construction and land development loans surged to $181 / 2$ percent by the end of 2009 , and the delinquency rate was $281 / 2$ percent for loans that financed the construction of one- to four-family residential properties (figure 12). Meanwhile, the charge-off rate on construction and land development loans reached 8 percent in the fourth quarter. The credit quality of other CRE lending categories deteriorated to a lesser degree but nevertheless appeared to still be worsening at yearend. Indeed, in the January 2010 SLOOS, banks reported expectations of further deterioration in the credit quality of CRE loans over 2010, an outlook that may be seen as a particular concern for smaller banks because their assets are more heavily concentrated in CRE lending. Smaller banks increased their concentration of lending in CRE loans over much of the past decade; at the end of 2009, CRE loans accounted for 
13. Change in commercial real estate loans, by major components, 1990-2009

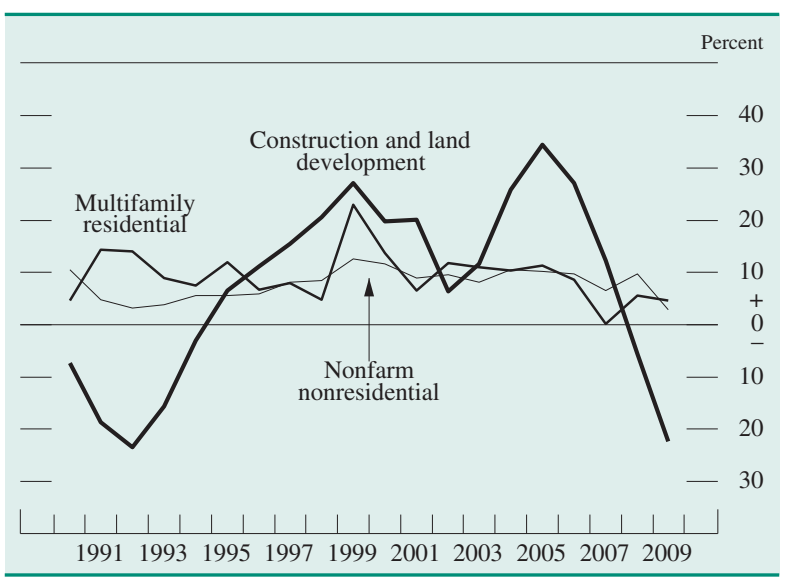

Nоте: The data are annual and adjusted for major structure events.

about 46 percent of total loans at such banks, compared with about 17 percent of loans at the 100 largest banks.

Banks' holdings of CRE loans fell 6 percent (adjusted for structure activity) in 2009, pulled down by a precipitous drop in loans to fund construction and land development, particularly of one- to fourfamily residential homes (figure 13). ${ }^{7}$ In contrast, loans secured by nonfarm nonresidential properties expanded modestly last year despite the worsening fundamentals in commercial property markets. Some of this relative strength may reflect a substitution away from C\&I loans: Given the substantial deterioration in the credit quality of banks' business loan portfolios, some banks reportedly sought stronger collateral for business loans, which may have included forms of real estate. In such cases, the loans would have shifted from the C\&I category to loans secured by nonfarm nonresidential real estate. Nonetheless, even growth of nonfarm nonresidential loans slowed over the second half of the year. In other CRE lending, loans backed by multifamily properties grew mildly over most of 2009 but dropped in the fourth quarter.

\section{Household Loans}

Banks' holdings of loans to households also declined broadly in 2009. Adjusted for structure activity, residential real estate loans on banks' books decreased $13 / 4$ percent and consumer loans fell $4 \frac{1}{4}$ percent.

Following the financial crisis, households took steps to strengthen their balance sheets. The house-

7. Outstanding loans to fund the construction of one- to four-family residential homes totaled only $\$ 86$ billion at year-end, less than one-half of their peak during the first quarter of 2008.
14. Indicators of household financial stress, 1993-2009

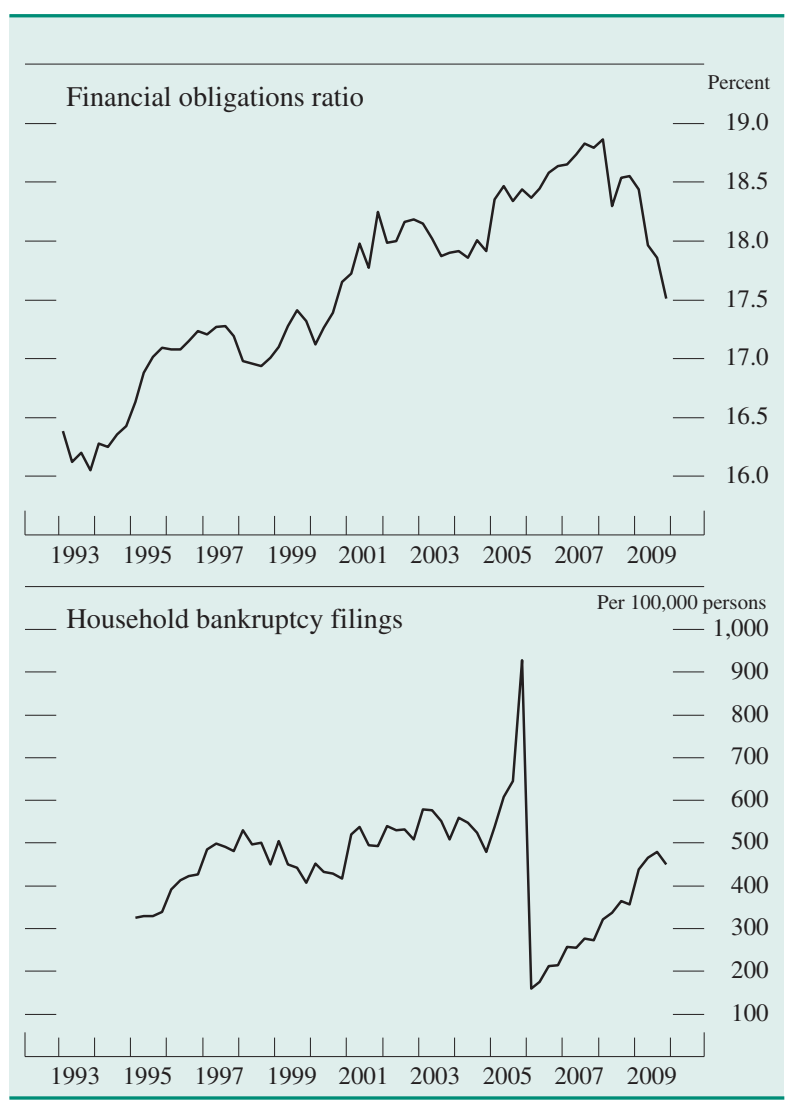

Note: The data are quarterly. The financial obligations ratio is an estimate of debt payments and recurring obligations as a percentage of disposable personal income; debt payments and recurring obligations consist of required payments on outstanding mortgage debt, consumer debt, auto leases, rent, homeowner's insurance, and property taxes. The series shown for bankruptcy filings begins in 1995:Q1 and is seasonally adjusted.

SOURCE: For financial obligations ratio, Federal Reserve Board (www.federalreserve.gov/releases/housedebt); for bankruptcy filings, staff calculations based on data from Lundquist Consulting.

hold financial obligations ratio-an estimate of debt payments and recurring obligations as a percentage of disposable income-fell over 2009 to end the year at its lowest level since 2000; this movement is consistent in part with households paying down debt to reduce their interest and principal burdens (figure 14). In addition, the personal saving rate increased markedly since the beginning of 2008 .

However, the combination of low mortgage rates, a tax credit for first-time homebuyers, and improved home affordability likely contributed to the strengthened demand for prime mortgages reported in the SLOOS over the first three quarters of 2009 (figure 15). Compared with 2008, originations of firstlien residential mortgages by commercial banks as a whole rose in 2009.

The decrease in banks' holdings of residential real estate loans last year was attributable to their substantial sales of such loans to the GSEs, their tight lending 
15. Change in prices of existing single-family homes, 1990-2009

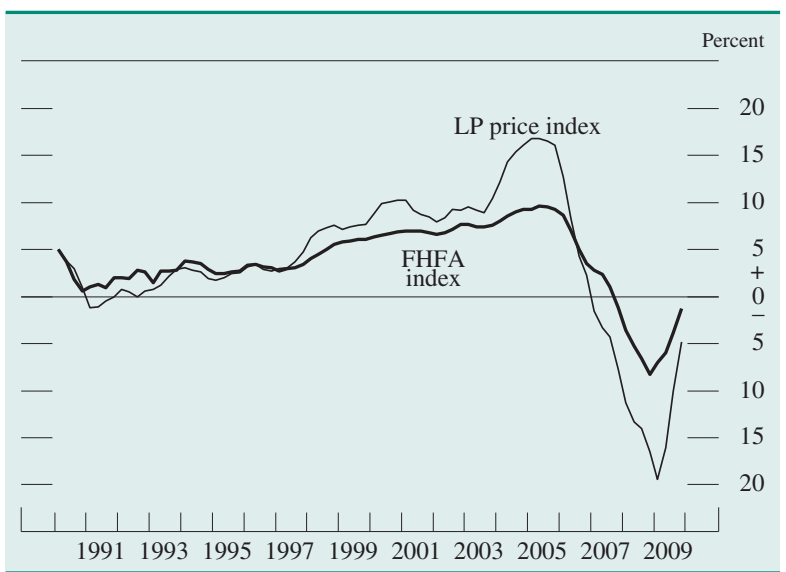

NotE: The data are quarterly and extend through 2009:Q4; changes are from one year earlier. The LP price index includes purchase transactions only. For 1990, the FHFA index (formerly calculated by the Office of Federal Housing Enterprise Oversight) includes appraisals associated with mortgage refinancings; beginning in 1991, it includes purchase transactions only.

SOURCE: For LP, LoanPerformance, a division of First American CoreLogic; for FHFA, Federal Housing Finance Agency.

standards in an environment of declining home values and high unemployment, and few originations of nontraditional or subprime loans by banks.

The deterioration in the credit quality of banks' closed-end residential real estate loans showed little, if any, sign of abating in 2009 (figure 16). National data on rates of serious delinquency worsened considerably for all classes of borrowers and types of mortgages. Delinquency rates on variable-rate mortgages in particular continued to increase more than those on fixed-rate loans, especially for subprime borrowers (figure 17). Of all major loan classes, banks recorded the highest delinquency rate for residential real estate loans, and the charge-off rate in this category was also very elevated. Banks' holdings of foreclosed real estate rose in 2009 but remained low relative to delinquency rates; such holdings equaled about $1 / 2$ percent of the value of outstanding closedend residential mortgages by year-end.

The credit quality of first- and junior-lien closedend residential mortgages diverged last year. Delinquency and charge-off rates for first liens worsened throughout the year, but the delinquency rate for junior liens stabilized in the second half of the year. The latter development may be explained by the very sharp increase in the charge-off rate on junior liens, as these loans are associated with lower recovery rates and tend to be charged off sooner after becoming delinquent than first liens. In contrast, delinquency and charge-off rates for revolving, open-end home equity loans were about flat for most of the year, likely reflecting banks' tightening of standards on
16. Delinquency and charge-off rates for residential real estate loans at commercial banks, by type of loan, 1991-2009

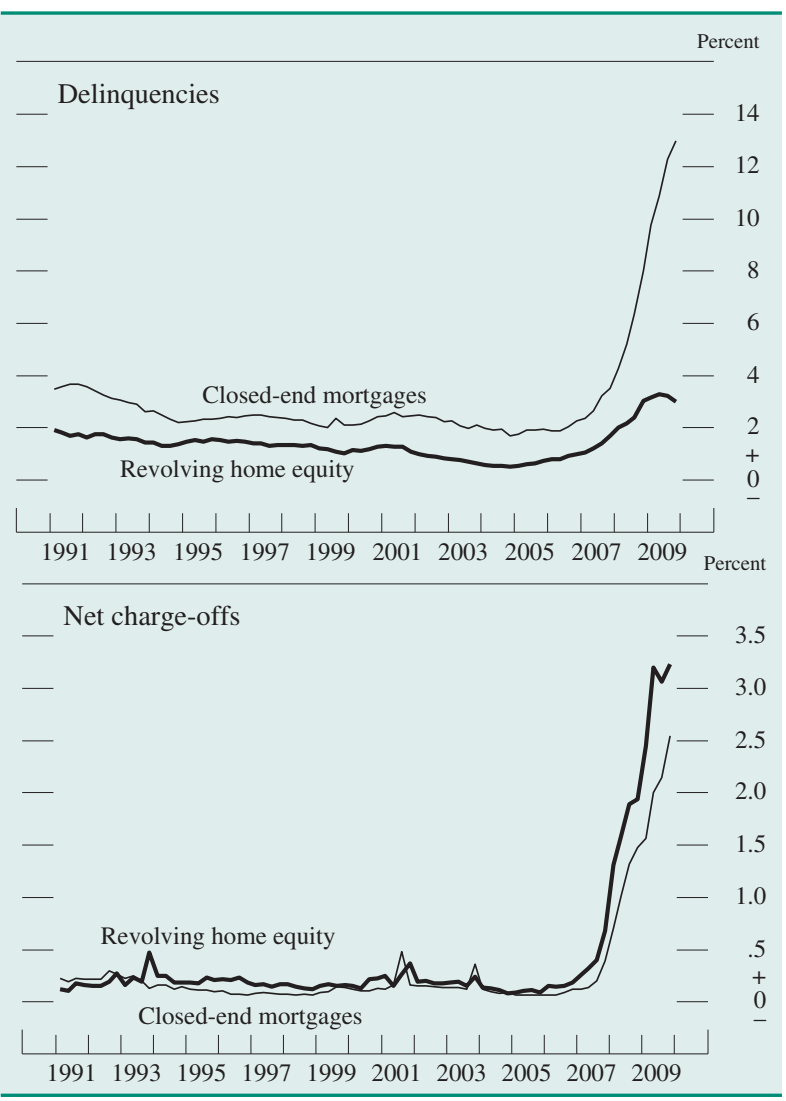

NOTE: The data are quarterly and seasonally adjusted. For definitions of delinquencies and net charge-offs, see the note for figure 9 .

17. Rate of serious delinquency on residential mortgages, by type of mortgage and type of interest rate, 2000-10

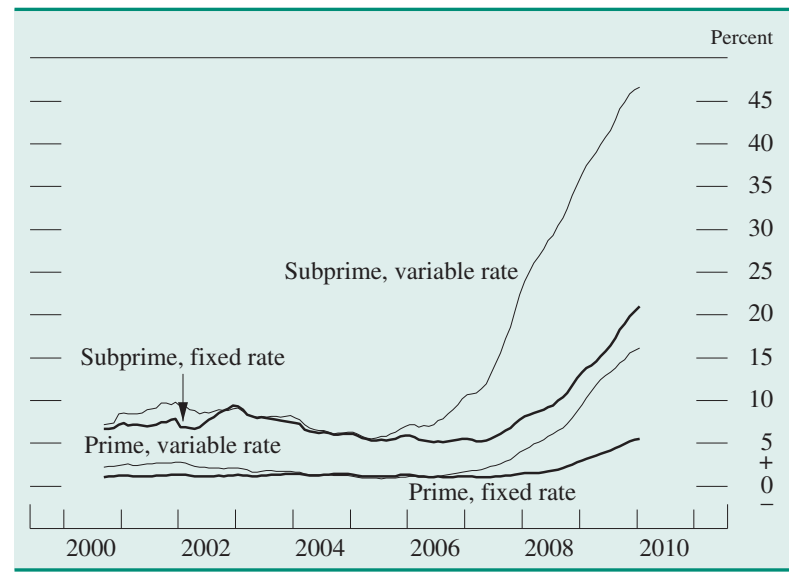

NoTE: The data are monthly and extend through January 2010. Seriously delinquent loans are 90 days or more past due or in foreclosure. The prime mortgage data are representative of all residential mortgages, not just those held by commercial banks. The subprime mortgage data cover only securitized loans.

SOURCE: For prime mortgages, McDash Analytics; for subprime mortgages, LoanPerformance, a division of First American CoreLogic. 
18. Delinquency and charge-off rates for loans to households, by type of loan, 1990-2009

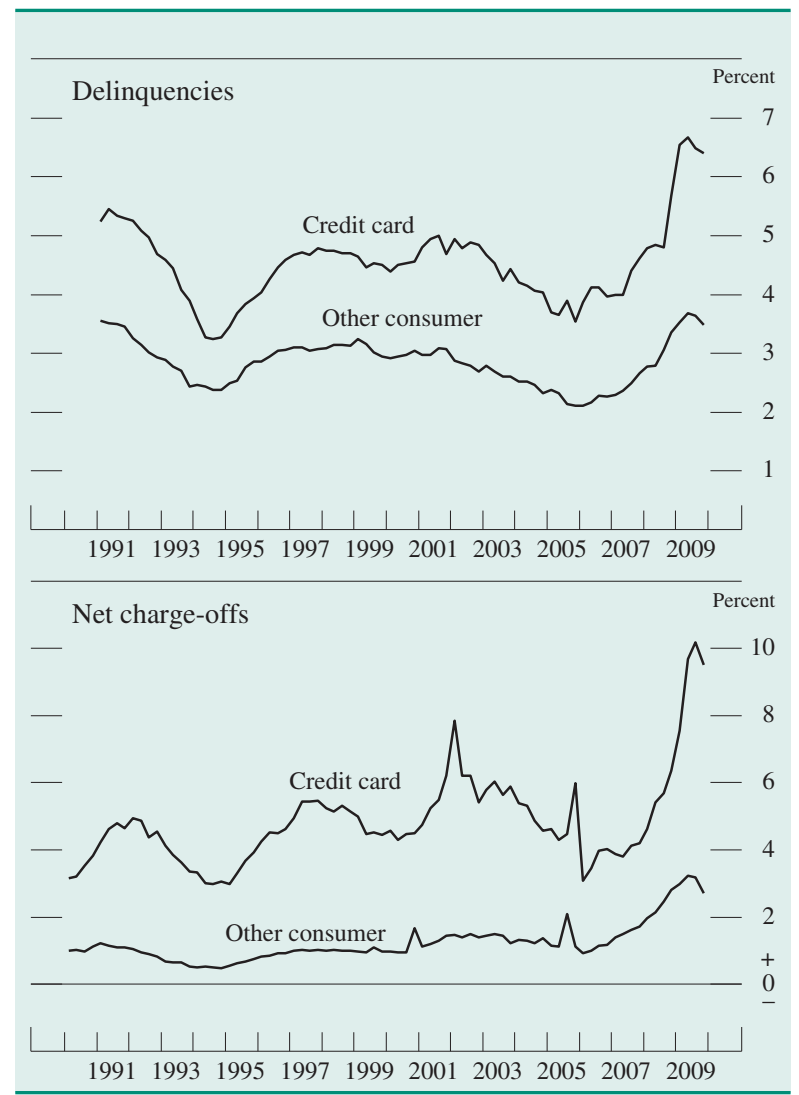

Note: The data are quarterly and seasonally adjusted; data for delinquencies begin in 1991. For definitions of delinquencies and net charge-offs, see the note for figure 9.

such loans over the past several years and their ability to reduce credit lines for borrowers with impaired home values.

Non-credit-card consumer loans expanded somewhat in the second half of 2009, perhaps in part as a result of frictions in the student loan securitization market, which caused banks to retain more of such loans on their books. In addition, this category of lending may have benefited from a pickup in personal consumption expenditures on durable goods during the second half of the year.

In contrast, credit card loans declined substantially over the same period, likely for several reasons. These loans incurred the highest charge-off rates of any major loan category, directly reducing outstandings (figure 18). ${ }^{8}$ Also, banks tightened standards and

8. For a discussion of the change in bankruptcy law that was implemented in 2005 and its effect on credit card loans, see the box "The New Bankruptcy Law and Its Effect on Credit Card Loans," in Elizabeth Klee and Gretchen Weinbach (2006), "Profits and Balance Sheet Developments at U.S. Commercial Banks in 2005," Federal Reserve Bulletin, vol. 92 (June), p. A89.
19. Changes in supply conditions at selected banks for consumer lending and for consumer installment loans, 1996-2009

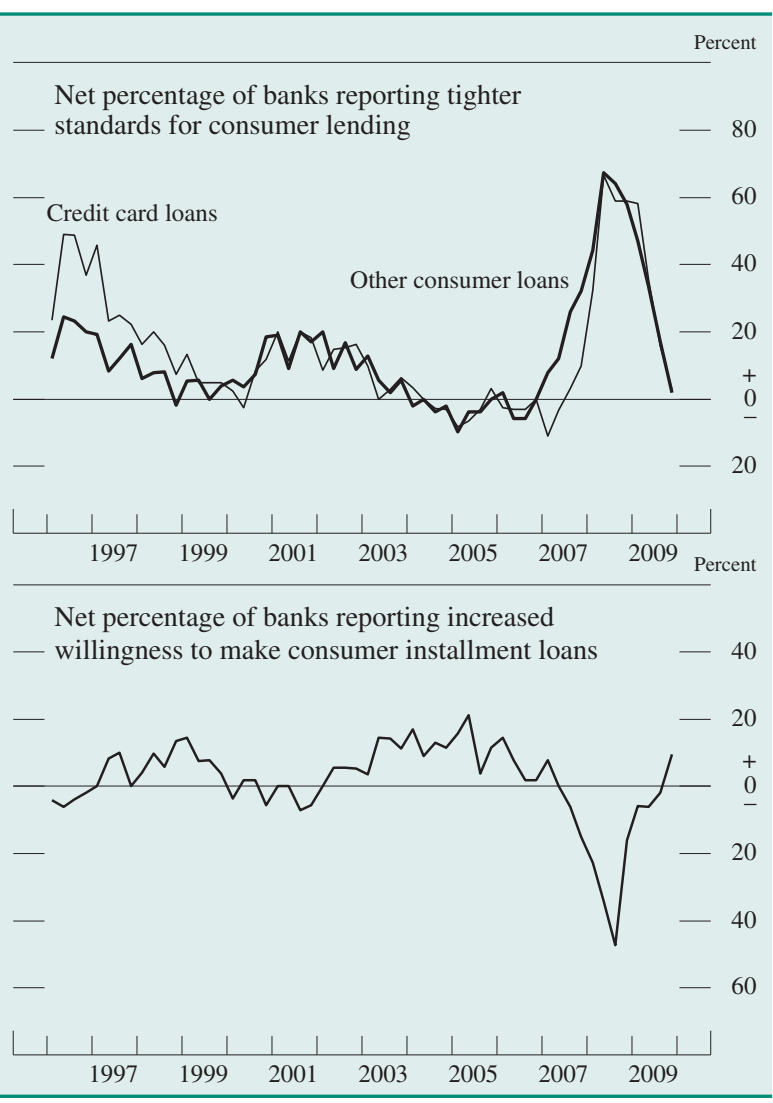

Note: See figure 8 , general note and source note.

terms on consumer loans (figure 19), partly in anticipation of new regulations. Households may also have reduced their use of credit cards in part to shore up their financial condition, a move that would be consistent with the reduced demand for consumer loans that was reported by notable net fractions of banks in the SLOOS during 2009.

By year-end 2009, the credit quality of consumer loans appeared to have begun to stabilize. The delinquency and charge-off rates on consumer loans declined slightly in the second half of the year but remained at historically high levels, particularly for credit card loans. In the January 2010 SLOOS, banks reported expecting no further deterioration, on net, in the credit quality of consumer credit card loans over 2010 , assuming that economic activity progressed in line with consensus forecasts; moderate net fractions of banks expected credit quality to improve for other consumer loans. The largest banks-which are responsible for the bulk of credit card lending - may have begun to benefit from the stabilization in credit 
quality on credit card loans, as evidenced by their reductions in loan loss provisioning during the fourth quarter.

\section{Other Loans}

All other loans and leases on banks' books, a volatile category, dropped $71 / 4$ percent over 2009 , about the same rate of decline as in 2008. Loans to other depository institutions were about flat for the year. Leases, which are made primarily to businesses for financing equipment or to households for financing automobiles, have been declining for most of the past decade and continued to do so in 2009, albeit at a somewhat faster rate. Bank lending to state and local governments grew during 2009 but not as rapidly as in recent years. Farm loans were about flat for the year, as farm banks have been less affected by the financial crisis, but growth of these loans weakened compared with past years given the wider macroeconomic downturn. The credit quality of farm loans also deteriorated in 2009 but was not notably worse than the average quality of these loans over the past two decades.

\section{Securities}

The decline in total loans over 2009 was partially offset by growth in banks' securities holdings of about 20 percent (adjusted for structure activity). While the expansion in securities was shared by banks of all sizes, it was strongest at the 100 largest banks. Amid heavy inflows of core deposits over the course of the year (discussed later in the article) and weak loan demand, banks increased their holdings of Treasury securities and agency non-MBS issues most rapidly, suggesting a preference for liquid, low-risk assets. A total of about $\$ 154$ billion of these securities was added to commercial banks' balance sheets over 2009 , an increase of roughly 67 percent over year-end 2008. The run-up occurred mostly at the 100 largest banks, which traditionally have held fewer of these securities as a share of total securities than smaller banks. Agency MBS, which accounted for roughly 37 percent of banks' securities holdings at year-end 2009, also grew strongly at the 100 largest banks.

In general, banks report both the book value (or amortized cost of acquisition) of their securities and the securities' current market value. The market value of the securities is affected by the credit quality of the issuers or of the assets that back the securities as well as by changes in the general level of interest rates. At the height of the credit market turmoil in the fall of 2008, the market value of many bank-held securities, particularly the non-agency MBS at the center of the crisis as well as the perpetual preferred securities issued by the GSEs, had declined considerably. However, the substantial decline in the general level of interest rates since the onset of the crisis has caused the market value of longer-duration assets with little credit risk to increase.

Over 2009, the difference between reported fair value measurements and book values of available-forsale securities in investment accounts narrowed, suggesting that banks have substantially lower revaluation losses on their current securities holdings than they did a year ago. At the end of 2008, banks reported net unrealized losses on investment account securities of about $\$ 60$ billion, led by losses on non-agency MBS and ABS, which were offset a bit by gains in other securities categories, particularly agency MBS. These net unrealized losses waned over 2009, as improving financial conditions and lower interest rates contributed to a recovery in the market prices of many securities. At the end of the fourth quarter, banks reported net unrealized gains of about $\$ 9$ billion on their investment account securities as a whole. ${ }^{9}$ Finally, banks sold some securities at a loss, which was reflected in the $\$ 1.7$ billion of total net realized losses on securities holdings over 2009.

\section{Cash Assets}

Cash assets, including reserve balances with Federal Reserve Banks, expanded considerably in late 2008, a pattern consistent with the considerable growth of the Federal Reserve's balance sheet. Usage of the special liquidity facilities established at the height of the financial crisis gradually fell over the first half of 2009, and reserve balances declined over the same period. However, as the Federal Reserve continued its large-scale asset purchases, reserve balances rose sharply in the third quarter. At year-end, the level of reserve balances was at a record high, accounting for 5 percent of industry assets. The interest rate paid on

9. In early April 2009, the Financial Accounting Standards Board issued guidance related to other-than-temporary impairments (OTTI), or FASB Staff Position (FSP) FAS 115-2, which required impairment write-downs through earnings only for the credit-related portion of a debt security's fair value impairment, while other components would affect other comprehensive income, which includes unrealized gains and losses on available-for-sale securities. (For more information on the guidance, see Financial Accounting Standards Board (2009), "Summary of Board Decisions," webpage, April 2, www.fasb.org/ action/sbd040209.shtml.) However, banks reported that the cumulative effect of the initial application of FSP FAS 115-2 on OTTI was only about $\$ 1.3$ billion in 2009 , having only a marginal effect on earnings relative to total unrealized gains and losses and fair value adjustments on securities. 
excess reserves held by banks remained at 25 basis points over the year.

\section{Off-Balance-Sheet Items}

For the second consecutive year, banks' off-balancesheet unused commitments to fund loans contracted steeply, and the runoff was widespread across all major commitment categories (figure 20). Responses to the SLOOS suggest that banks reduced credit lines for both new and existing customers and that those reductions were more prevalent for lower-quality borrowers. In addition, the cuts in lines likely reflected disproportionately the tightened lending standards by banks, as borrowers are presumably unlikely to request reductions in their line size since the marginal cost to borrowers of maintaining unused lines is typically small, especially for households.

Securitized loans, which are not held on banks' books, contracted 5 percent over 2009. ${ }^{10}$ Since the data began to be collected in 2002 , the only previous annual decline occurred in 2003, with a drop of $1 / 2$ percent. Last year's decline was likely in response to the impairment of many securitization markets for all or part of the period, as well as the weak lending environment. Securitized mortgages had risen considerably over 2007 and 2008 and still accounted for two-thirds of securitized loans at the end of 2009. However, with the market for non-agency MBS remaining shut last year, balances of securitized mortgages declined about 33/4 percent in 2009. The GSEs, though, continued to purchase large quantities of closed-end residential mortgages from banks.

Securitized credit card loans, which account for a further 20 percent of securitized loans, declined $83 / 4$ percent in 2009 . Most of this decline was due to the consolidation of securitized credit card assets in the fourth quarter by one large bank that adopted the new FAS 166 and 167 accounting rules at that time. ${ }^{11}$

10. Loans that banks sold or securitized with servicing rights retained or with recourse or other seller-provided enhancements are hereafter referred to, for simplicity, as "securitized" loans. The analysis excludes loans that were sold to, and securitized by, a third party (for example, the Federal National Mortgage Association or the Federal Home Loan Mortgage Corporation).

11. The Financial Accounting Standards Board (FASB) announced in June 2009 the publication of FAS 166, Accounting for Transfers of Financial Assets, and FAS 167, Amendments to FASB Interpretation No. 46(R) (Consolidation of Variable Interest Entities), which will change the way companies account for securitizations and special purpose entities. FAS 166 and 167 must be implemented with firms' first financial reporting period ending after November 15, 2009, which for commercial banks effectively means that the implementation will be reflected in their 2010:Q1 Call Reports. For more information, see the FASB's website at www.fasb.org. For more information about the balance sheets of commercial banks, see Board of Governors of the Federal Reserve System (2010), Statistical Release H.8, “Assets and
20. Change in unused bank loan commitments to businesses and households, 1990-2009

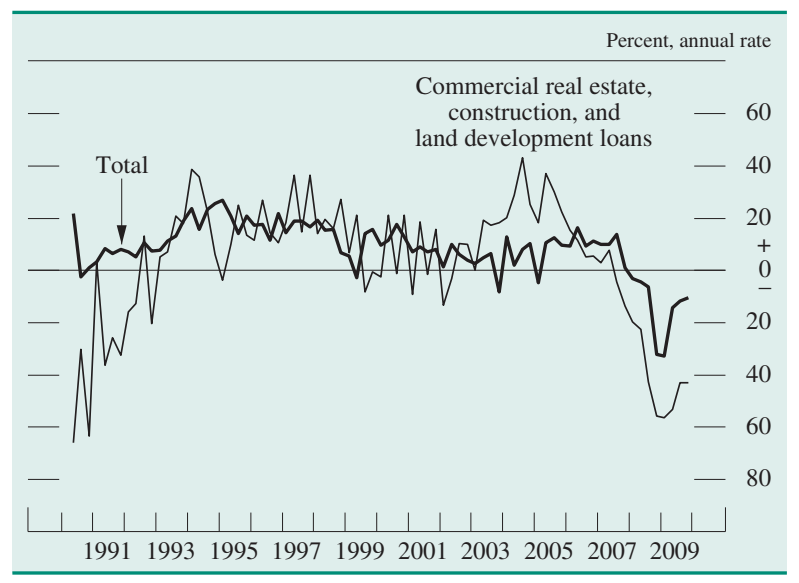

Note: The data, which are quarterly, begin in 1990:Q2 and are not seasonally adjusted. The total consists of unused commitments relating to credit card lines; revolving, open-end lines secured by one- to four-family residential properties; commercial real estate, construction, and land development loans; securities underwriting; and "other."

\section{DERIVATIVES}

In 2009, the notional principal amount of derivatives contracts held by banks grew a moderate $33 / 4$ percent to reach $\$ 220$ trillion (table 2). ${ }^{12}$ Notional values are boosted substantially by a few of the largest banks, which enter into offsetting positions in their capacities as dealers in derivatives markets. The fair market value of those derivatives contracts held by banks reflects the contracts' replacement costs and is far smaller than the notional principal amount. ${ }^{13}$ The aggregate fair market value for all bank contracts with a positive value in 2009 was about $\$ 4.1$ trillion; for all bank contracts with a negative value, the aggregate fair market value was roughly negative $\$ 3.9$ trillion. These fair values were considerably smaller relative to their notional values at the end of 2009 than they were at the end of 2008, due to the partial recovery in financial markets from the unprecedented market dislocations that occurred in the fall of 2008. Both the positive and negative fair values

Liabilities of Commercial Banks in the United States" (April 9), www.federalreserve.gov/releases/h8/current/default.htm.

12. Notional amounts are amounts from which contractual payments will be derived and, in most instances, are much larger than the amounts at risk; thus, they do not accurately represent the scope of economic involvement of banks with derivatives.

13. The total of all contracts with a positive fair value is a measurement of credit exposure, or the amount that a bank could lose if its counterparties did not fulfill their contracts. The total of all contracts with a negative fair value at a bank represents a measurement of exposure that the bank poses to its counterparties. Even these fair value amounts can overstate exposure, as counterparties often enter into bilateral "netting" agreements, which allow aggregation of all bilateral exposure into the equivalent of a single trade in the event of default of either party. 
2. Change in notional value and fair value of derivatives, all U.S. banks, 2004-09

Percent

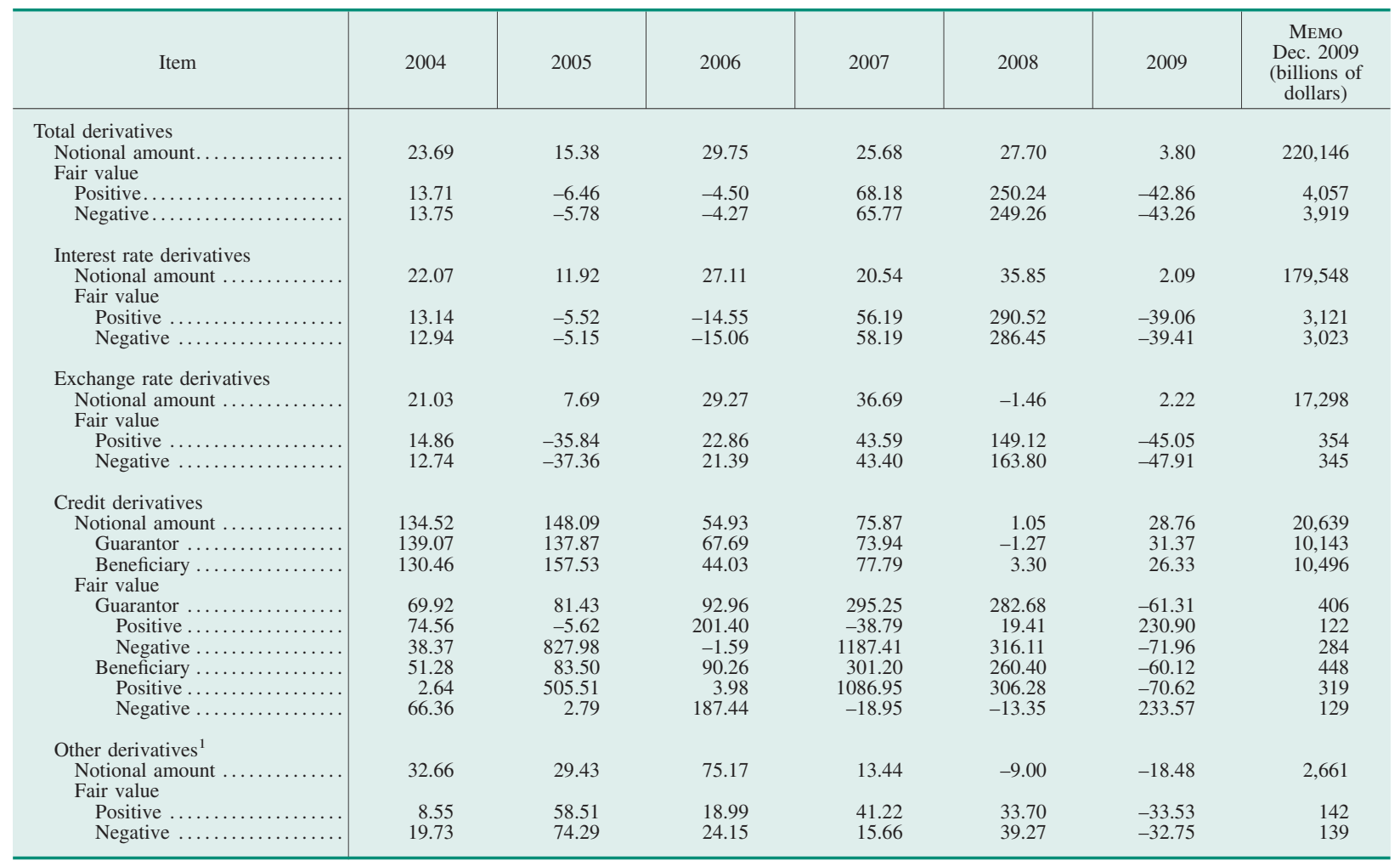

Note: Data are from year-end to year-end and are as of March 23, 2010.

1. Other derivatives consist of equity and commodity derivatives

and other contracts.

contracted substantially over the first half of 2009 , and each declined about 43 percent for the year as a whole.

Interest rate products continued to account for more than 80 percent of the notional value of derivatives products held by banks and about 77 percent of positive and negative fair values. Interest rate swaps, which account for most of the interest rate derivatives on banks' books, are an important way for banks to hedge interest rate risk, including that related to interest-sensitive assets such as mortgages and MBS. The notional amount of interest rate swaps declined $13 / 4$ percent over 2009 . In addition, both positive and negative fair values dropped substantially, likely in part because of the development of stable low interest rates over the year. Other interest rate derivatives include options, futures, and forwards, and the notional value of these other derivatives contracts grew 16 percent over 2009, in line with the pace in the past few years.

One of the fastest growing components of banks' derivatives portfolios in recent years has been credit derivatives, which, prior to last year, had expanded an average of about 70 percent per year since 2000 . After a pause in 2008 , credit derivatives resumed growth in 2009. ${ }^{14}$ The notional amount of these derivatives grew 29 percent for the year, and at year-end 2009, credit derivatives accounted for $91 / 2$ percent of the notional principal value of all derivatives contracts held by banks. By contrast, the fair value of credit derivatives contracts fell 60 percent in 2009, and these products constituted about 11 percent of positive and negative fair values at banks at year-end. These fair values started to decline in the spring of 2009 but remained high relative to historical norms due to the elevated spreads on many of the underlying reference entities. Over the course of the year, as spreads on underlying reference entities receded and overall market functioning improved, the value of such credit protection (the fair values of the credit derivatives) declined. Credit default swaps accounted

14. The flattening in notional values of credit default swaps during 2008, however, appears to have been due in part to organized efforts to compress offsetting trades and not simply to a reduction in trading activity. 
for 98 percent of the notional value of credit derivatives held by banks throughout the year (total return swaps and credit options are two other common types). Banks are beneficiaries of protection when they buy credit derivatives contracts and providers of protection (guarantors) when they sell them. Banks are typically net beneficiaries of protection; as of year-end, contracts in which banks were beneficiaries of protection totaled $\$ 10.5$ trillion in notional value, and contracts in which they were guarantors totaled $\$ 10.1$ trillion (figure 21).

Banks also use derivatives related to foreign exchange, equities, and commodities. Collectively, those instruments accounted for about 9 percent of the notional value of the derivatives contracts held by banks at year-end. Banks' notional holdings of foreignexchange-related derivatives grew $2 \frac{1 / 4}{4}$ percent in 2009. Their notional holdings of equity and commodity derivatives together fell $181 / 2$ percent, a second consecutive annual decline.

The share of industry derivatives contracts (in terms of notional value) at the 10 largest banks (in terms of assets) had for years been more than 97 percent, a concentration ratio that reflected the role that some of the largest banks play as dealers in derivatives markets. However, since the end of 2008 , that share has declined to about 80 percent, as the reorganization of a prominent derivatives dealer involved booking these derivatives at one of its commercial bank subsidiaries that remained outside of the 10 largest banks at the end of 2009. Still, banks' derivatives holdings were highly concentrated over the past two years: The 5 banks with the most derivatives activity in 2009, including 1 bank not among the 10 largest

21. Notional amounts of credit derivatives for which banks were beneficiaries or guarantors, 2000-09

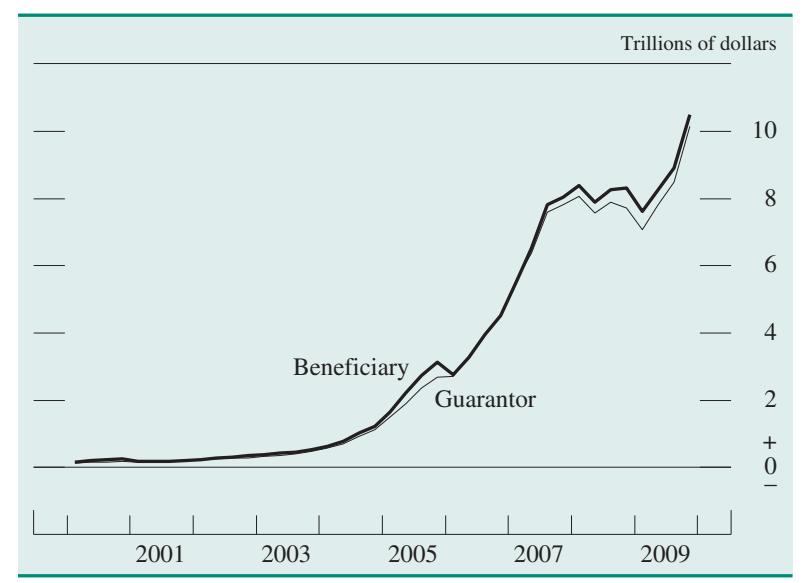

NoTE: The data are quarterly. banks by assets, held 96 percent of all derivatives by notional amounts. ${ }^{15}$

\section{LIABILITIES}

Total liabilities on banks' books declined about $5 \frac{1}{2}$ percent in 2009. Adjusting for major structure events, liabilities contracted 63/4 percent. As was true of the decrease in assets, the decline in liabilities was concentrated at the 100 largest banks. The runoff in liabilities took place in the context of deleveraging by banking institutions amid weak loan demand and tight credit standards; banks reduced assets, raised capital, and pared back relatively more expensive sources of funding. Thus, banks did not compete strongly for managed liabilities or small time deposits, and declines in those components accounted for the contraction of overall liabilities. Indeed, small time deposits shrank substantially over 2009, reversing a steep run-up during the height of the financial crisis in late 2008, after which the spreads between rates on time and savings deposits declined markedly.

While overall liabilities contracted, total core deposits grew about 8 percent in 2009, well above the average pace during years prior to the financial crisis. As a result, for the second consecutive year, core deposits rose as a share of bank funding. ${ }^{16}$ Amid low market interest rates, the opportunity cost of holding liquid deposits remained low in 2009, and consequently savings and transaction deposits grew sizably (figure 22). With money market rates unusually low, money market mutual funds experienced large outflows, some of which may have ended up at banks as the public sought the safety and liquidity of insured deposits (figure 23). Reinforcing this trend was the extension through 2013 of the temporary increase in the Federal Deposit Insurance Corporation's maximum deposit insurance amount to $\$ 250,000$, which previously had been in place only through the end of 2009. ${ }^{17}$ The FDIC also extended, until the end of June 2010, its program providing unlimited guarantees of transaction accounts, although the new higher annual assessment rates for participating banks caused many large institutions to opt out of the program at year-end 2009.

Managed liabilities contracted $16^{1 / 2}$ percent over 2009. Given strong growth of core deposits and

15. Office of the Comptroller of the Currency, OCC's Quarterly Report on Bank Trading and Derivatives Activities, Third Quarter 2009 (Washington: OCC), available at www.occ.treas.gov/deriv/ deriv.htm.

16. Core deposits consist of savings deposits (including money market deposit accounts), small-denomination time deposits, and transaction deposits.

17. This extension became effective on May 20, 2009. 
22. Selected domestic liabilities at banks as a proportion of their total domestic liabilities, 1990-2009

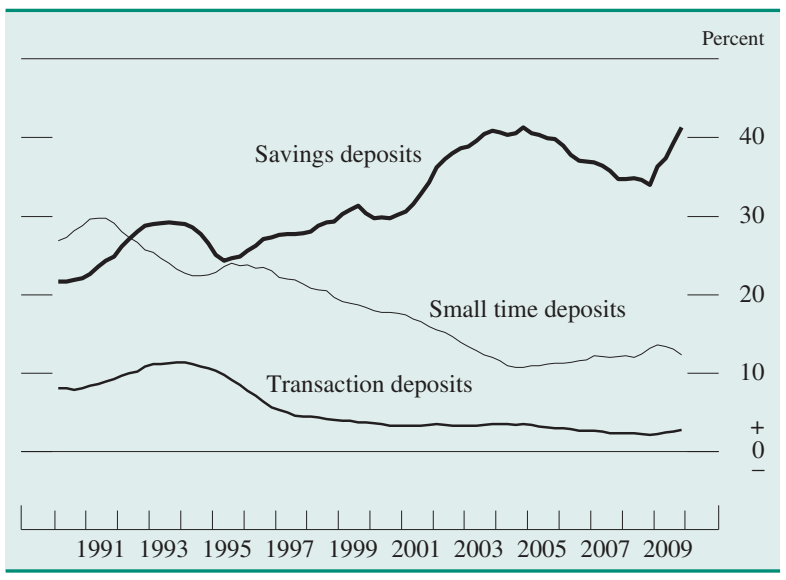

NoTE: The data are quarterly. Savings deposits include money market deposit accounts.

shrinking assets, banks were able to continue reducing their reliance on these generally more expensive and less stable sources of funds. Large time deposits ran off appreciably, while deposits booked in foreign offices were about flat for the year. In addition to paring back advances from the Federal Home Loan Banks over the course of the year, commercial banks decreased their borrowings from the Federal Reserve liquidity facilities introduced during the crisis. ${ }^{18} \mathrm{Net}$ borrowings in the federal funds market declined in light of banks' hefty reserve holdings.

Banking institutions issued about $\$ 300$ billion of debt under the debt guarantee portion of the FDIC's Temporary Liquidity Guarantee Program (TLGP), which was established in October 2008. The TLGP guarantees, in exchange for a fee, short- and mediumterm debt maturing on or before December 31, 2012. About five-sixths of this debt was issued by bank holding companies (BHCs) and so does not appear directly as long-term debt at the bank level. The program was used most heavily before the summer of 2009. After the results of the Supervisory Capital Assessment Program were released in May, many banks were able to issue sufficient amounts of debt without the guarantee. In October, the FDIC ended the Debt Guarantee Program component of the TLGP

18. The Federal Home Loan Banks (FHLBs) were established in 1932 as GSEs chartered to provide a low-cost source of funds, primarily for mortgage lending. They are cooperatively owned by their member financial institutions, a group that originally was limited to savings and loan associations, savings banks, and insurance companies. Commercial banks were first able to join FHLBs in 1989, and since then FHLB advances have become a significant source of funding for them, particularly for medium-sized and small banks. The FHLBs are cooperatives, and the purchase of stock is required in order to borrow.
23. Net flows into money market mutual funds and deposits at commercial banks, 2007-09

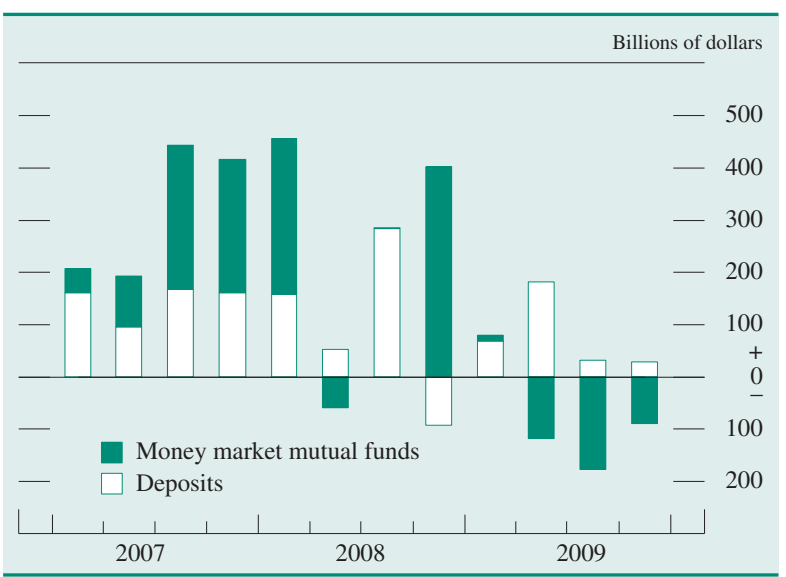

Note: The data are aggregated from weekly to quarterly frequency.

SoURCE: For money market mutual funds, iMoneyNet; for deposits, Federal Reserve Board, Statistical Release H.8, "Assets and Liabilities of Commercial Banks in the United States" (www.federalreserve.gov/ releases/h8).

and established a new, limited emergency guarantee facility in order to promote the transition of banking institutions away from such support.

\section{CAPITAL}

The banking industry shored up its capital position in 2009. The equity capital of commercial banks rose to about $11 \frac{1}{4}$ percent of assets by the end of 2009, up considerably from about $91 / 2$ percent at the end of 2008. The increase was due largely to substantial infusions of capital from parent BHCs throughout the year. Total capital transfers in 2009 amounted to $\$ 113$ billion. These additions augmented the large transfers that occurred in the fourth quarter of 2008 (figure 24). In many cases, the transfers reflected the

24. Capital transfers to commercial banks from parent bank holding companies, 1990-2009

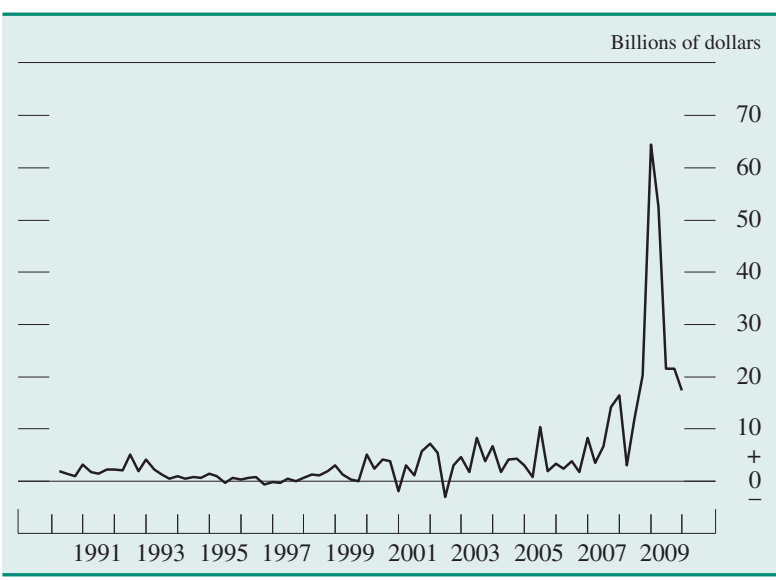

NотE: The data are quarterly. 
downstreaming of capital raised by the parent BHC through the Troubled Asset Relief Program's Capital Purchase Program (CPP). Although many BHCs repaid CPP funds during the second half of 2009, most of that equity was replaced by secondary equity issuance by large BHCs that had been evaluated under the SCAP. As public equity markets improved further in the second half of 2009, other banks were also able to issue new shares to build capital or repay CPP investments. (For more information, see box "The Capital Purchase Program and the Supervisory Capital Assessment Program.")

Retained earnings as a share of total equity dropped from about 27 percent at the end of 2008 to about 22 percent at the end of 2009. That component was reduced by declared dividends that exceeded profits for the second consecutive year, even though such payouts as a percentage of average assets were at historically low levels. A large majority of the dividends were declared by banks in the top five BHCs. These relatively more profitable institutions repaid their CPP funds in the second half of 2009 and were not subject to the restrictions on dividends at the BHC level that are associated with the receipt of TARP funds. ${ }^{19}$ For the entire year, dividends at profitable banks amounted to 0.55 percent of average assets, while dividends at the other banks amounted to only 0.04 percent.

On balance, all three regulatory capital ratios increased to record levels (figure 25). The leverage ratio increased by 1 percentage point to about $81 / 2$ percent by the end of $2009 .{ }^{20}$ The tier 1 and total risk-based capital ratios, measured relative to riskweighted assets, each increased substantially-from about $93 / 4$ percent to $11^{1 / 2}$ percent and from about $123 / 4$ percent to $141 / 4$ percent, respectively. ${ }^{21}$ Reduc-

19. The top five BHCs are ranked by the combined assets of commercial bank subsidiaries for a given BHC. As of the fourth quarter of 2009, the top five BHCs had 28 commercial bank subsidiaries, which accounted for about 52 percent of total commercial bank assets. For more information on the dividend restrictions, see the public term sheet for the CPP, which is an attachment to U.S. Department of the Treasury (2008), "Treasury Announces TARP Capital Purchase Program Description," press release, October 14, www.ustreas.gov/press/releases/hp1207.htm.

20. The leverage ratio is the ratio of tier 1 capital to average tangible assets. Tangible assets are equal to total average consolidated assets less assets excluded from common equity in the calculation of tier 1 capital.

21. Tier 1, tier 2, and tier 3 capital are regulatory measures. Tier 1 capital consists primarily of common equity (excluding intangible assets such as goodwill and excluding net unrealized gains on investment account securities classified as available for sale) and certain perpetual preferred stock. Tier 2 capital consists primarily of subordinated debt, preferred stock not included in tier 1 capital, and loan loss reserves up to a cap of 1.25 percent of risk-weighted assets. Tier 3 capital is short-term subordinated debt with certain restrictions on repayment provisions and is limited to approximately 70 percent of a
25. Regulatory capital ratios, 1990-2009

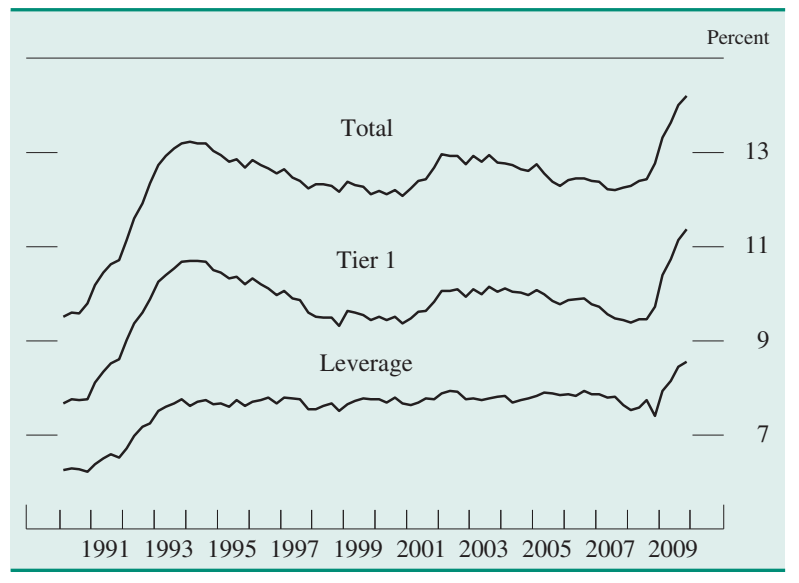

Note: The data are quarterly. For the components of the ratios, see text notes 20 and 21 .

tions in risk-weighted assets and average tangible assets as well as increased capital contributed to higher regulatory capital ratios in 2009 . The reduction in risk-weighted assets was partly attributable to a shift in the composition of assets from loans to cash and securities, while total assets shrank as loans outstanding on banks' books ran off steeply last year.

Several factors likely contributed to banking institutions' efforts to boost capital. First, some of the largest banking organizations were required to augment their capital as a result of the SCAP process. Second, a few banks faced substantial increases in both risk-weighted and total assets associated with the large amounts of off-balance-sheet assets that are required to be consolidated on banks' balance sheets by the end of the first quarter of 2010 in conjunction with the adoption of Statements of Financial Accounting Standards Nos. 166 and 167. Those consolidations may have led some institutions to add to their capital prior to the accounting change. ${ }^{22}$ Third, capital is generally considered a buffer to protect uninsured depositors and other

bank's measure for market risk. Total regulatory capital is the sum of tier 1, tier 2, and tier 3 capital. Risk-weighted assets are calculated by multiplying the amount of assets and the credit-equivalent amount of off-balance-sheet items (an estimate of the potential credit exposure posed by the items) by the risk weight for each category. The risk weights rise from 0 to 1 as the credit risk of the assets increases. The tier 1 ratio is the ratio of tier 1 capital to risk-weighted assets; the total ratio is the ratio of the sum of tier 1 , tier 2 , and tier 3 capital to risk-weighted assets.

22. Banks have an option to phase in the effects of the implementation of FAS 166 and 167 on risk-weighted assets and tier 2 capital over four quarters. See Board of Governors of the Federal Reserve System, Federal Deposit Insurance Corporation, Office of the Comptroller of the Currency, and Office of Thrift Supervision (2010), "Agencies Issue Final Rule for Regulatory Capital Standards Related to Statements of Financial Accounting Standards Nos. 166 and 167," press release, January 21, www.federalreserve.gov/newsevents/press/ bcreg/20100121a.htm. 


\section{The Capital Purchase Program and the Supervisory Capital Assessment Program}

In 2009, parent bank holding companies (BHCs) transferred a record level of capital to commercial banks within their organizational structures. Such transfers resulted in significantly higher regulatory capital ratios for those subsidiary banks. The capital transfers themselves were initially supported by large injections of government capital at the BHC level through the Troubled Asset Relief Program (TARP), launched in October 2008, and primarily through the TARP Capital Purchase Program (CPP). ${ }^{1}$ The CPP initially was allotted $\$ 250$ billion to purchase senior preferred shares of financial institutions in order to stabilize the financial system by increasing the capital base of financial institutions and to support their capacity to make loans to businesses and households. Financial institutions participating in the program agreed to pay the Treasury a 5 percent dividend on the preferred shares per year for the first five years and 9 percent per year thereafter. At the end of 2008, the CPP had almost $\$ 180$ billion invested in more than 200 financial institutions. Most of the capital was committed to the largest U.S. financial institutions (figure C, top panel). By the end of 2009, more than 650 institutions had received CPP investments. CPP balances peaked at close to $\$ 200$ billion in the second quarter, but afterward many banks began to repay those investments. As of year-end, CPP balances had fallen to less than $\$ 85$ billion.

A turning point in the outstanding balances of the CPP program was the Supervisory Capital Assessment Program (SCAP), otherwise known as the bank stress tests. Led by the Federal Reserve, the U.S. federal banking supervisory agencies conducted the SCAP from February to April 2009 and released the results in May. ${ }^{2}$ The objective

1. The Treasury also purchased preferred stock at Citigroup, Inc., and Bank of America Corporation through the TARP Targeted Investment Program (TIP). Both institutions fully repaid their TIP balances in the fourth quarter of 2009 .

2. For an overview of the results, see www.federalreserve.gov/ bankinginforeg/scap.htm. of the SCAP was to conduct a comprehensive, consistent, and simultaneous assessment of capital needs across the 19 largest BHCs using a common set of macroeconomic scenarios and a common forward-looking framework. ${ }^{3}$ More specifically, the SCAP estimated losses, revenues, and loss reserve needs for the next two years under two macroeconomic scenarios. ${ }^{4}$ The program was designed to assess the need for a BHC to raise or improve the quality of capital in order to have sufficient capital buffers to sustain lending even in a more adverse economic scenario. The SCAP results identified $10 \mathrm{BHCs}$ as requiring additional capital or higher-quality capital. The detailed publication of the SCAP results also helped clarify the financial conditions of the largest $\mathrm{BHCs}$ and provided investors with greater assurance about the health of these institutions. The resulting improvement in market sentiment regarding banking institutions, reinforced by the stabilization of the economic outlook at the time, allowed the BHCs to tap capital markets for substantial funds. Most of the 19 BHCs included in the SCAP issued equity, some to raise their required SCAP buffer and some to repay the

3. The following 19 BHCs were in the SCAP: American Express Company; Bank of America Corporation; The Bank of New York Mellon Corporation; BB\&T Corporation; Capital One Financial Corporation; Citigroup, Inc.; Fifth Third Bancorp; GMAC LLC; The Goldman Sachs Group, Inc.; JPMorgan Chase \& Co.; KeyCorp; MetLife, Inc.; Morgan Stanley; PNC Financial Services Group, Inc.; Regions Financial Corporation; State Street Corporation; SunTrust Banks, Inc.; U.S. Bancorp; and Wells Fargo \& Company Bank Holding Company.

4. The two scenarios consisted of a "baseline scenario" and a "more adverse scenario." The baseline scenario relied on a consensus view about the depth and duration of the recession, assuming real GDP growth and the unemployment rate for 2009 and 2010 equal to the average of the projections published by Consensus Forecasts, the Blue Chip survey, and the Survey of Professional Forecasters as of February 2009. In addition, house prices were assumed to be in line with futures prices for the S\&P/CaseShiller 10-city composite index in late February and with the average response to a special question on house prices in the Blue Chip survey. The more adverse scenario was designed to characterize a recession longer and more severe than the consensus expectation, with house prices assumed to be significantly lower by the end of 2010 than in the baseline scenario. senior stakeholders against unexpected losses that a bank may potentially incur beyond what it has set aside in reserves. In the current uncertain economic environment, banks may want a larger than usual buffer. Moreover, banks' loan loss reserves-which are intended to cover estimated likely credit losseshave fallen to very low levels relative to their delinquent loans and charge-offs, even as certain sectors of the economy to which many banks have significant exposures, such as commercial real estate, remain fragile. Finally, both national and international authorities are considering tightening capital requirements in light of the crisis.

Although not part of regulatory capital, accumulated other comprehensive income (AOCI), which includes net unrealized gains and losses on availablefor-sale securities and accumulated net gains and losses on cash flow hedges, continued to play an important role as a component of equity last year. Particularly during the period of greatest stress on the banking system in late 2008 and the first half of 2009, market participants focused on various measures of tangible common equity (TCE) relative to tangible or risk-weighted assets as important indicators of banks' financial condition. These measures usually incorporated AOCI in the calculation of tangible capital. The increase in AOCI, which was largely due to the notable reduction in unrealized losses on availablefor-sale securities, helped improve industry TCE ratios in 2009. 
Treasury investments through the CPP and, eventually, other TARP programs (figure $\mathrm{C}$, bottom panel). Other banks also issued equity in the second half of 2009 to bolster their capital or repay CPP investments. The preferred shares owned by the government were replaced primarily with common stock held by private investors. Reflecting the inflow of both government and private capital to BHCs, capital transfers by the BHCs to their commercial bank subsidiaries were strong throughout 2009.

While the CPP and SCAP helped reduce the uncertainty about the capital adequacy of large financial institutions and contributed to improved market functioning, it is difficult to assess the extent to which the CPP and SCAP succeeded in fostering lending to creditworthy businesses and households. Banks' lending activity, as measured by the sum of total loans and unused loan commitments outstanding, fell substantially last year, and lending standards and terms continued to tighten according to the Federal Reserve's Senior Loan Officer Opinion Survey on Bank Lending Practices. However, some of the fall in credit was likely due to weaker demand by households and businesses as the economy remained fragile. In addition, at least some tightening of credit standards and terms is also to be expected when economic growth is weak or uncertain, and so a tightening may not reflect pressures on capital. Indeed, credit might have been even weaker and lending standards even tighter without the programs.

One can say, however, that the cumulative magnitude of the capital transfers that were stimulated by the CPP and SCAP was substantial. Without the capital transfers from parent BHCs since the fourth quarter of 2008, the regulatory capital ratios of commercial banks would have been $1 \frac{1}{2}$ to 2 percentage points lower at the end of 2009 . Although some of that difference in regulatory capital ratios in the absence of the CPP likely would have been made up through other means, such as stock sales and conversions, a further decrease in risk-weighted assets and average tangible assets may also have resulted.
C. Outstanding balance in the Capital Purchase Program, and cumulative gross secondary equity issuance, October 2008-February 2010

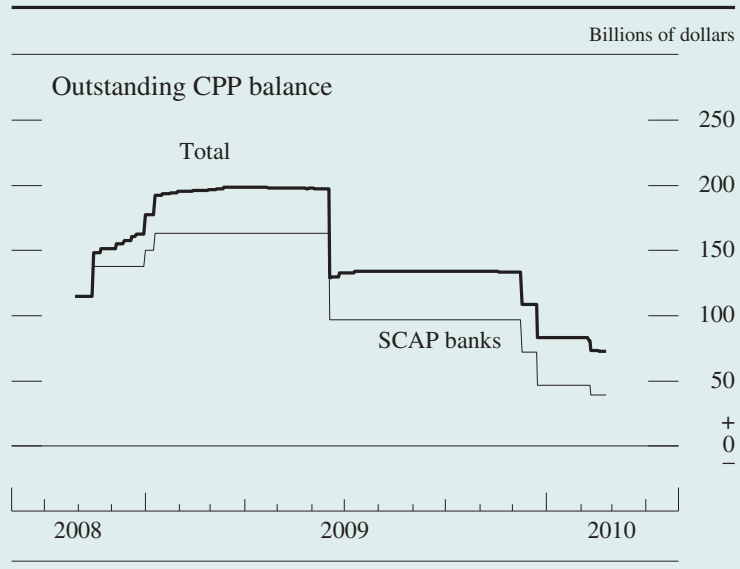

Cumulative gross secondary equity issuance

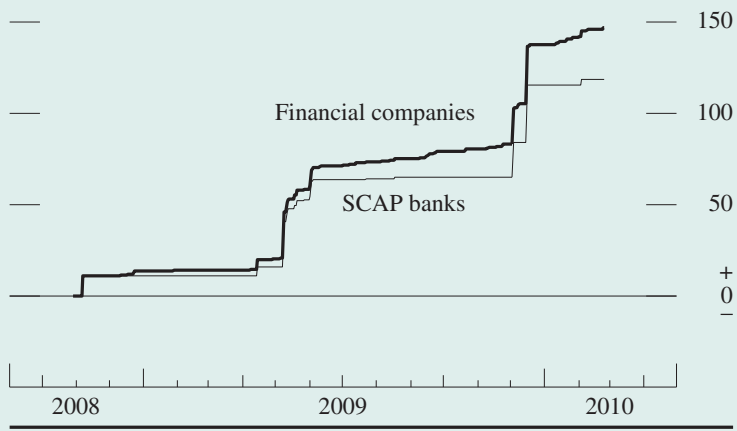

Note: The data are daily and extend from October 28, 2008, to February 24, 2010. CPP is the Capital Purchase Program; SCAP is the Supervisory Capital Assessment Program.

SOURCE: For outstanding CPP balance, Department of the Treasury; for cumulative gross secondary equity issuance, Securities Data Corporation New Issues Database.

\section{TRENDS IN PROFITABILITY}

Total annual net income of the commercial banking industry as a percentage of average assets remained depressed in 2009, as profits were weighed down by high levels of loss provisioning. Elevated provisions were offset by higher noninterest income, particularly income from capital-market-related activities. Net interest margins remained basically unchanged, and noninterest expense edged down despite significant increases in FDIC assessments. Notably, large banks posted a small profit, on balance, while other banks ended the year with an aggregate loss.

Return on assets for the banking industry as a whole stayed very low by historical standards at 0.04 percent, and return on equity was 0.42 percent, with both profitability measures depressed by el-

evated loss provisioning amid the deterioration in credit quality. Banks increased provisioning to 1.95 percent of industry average consolidated assets in 2009, up from 1.48 percent in 2008. At the same time, charge-offs surged to 1.47 percent of industry assets-compared with 0.83 percent in 2008limiting the rise in the stock of loan loss reserves, and delinquency rates increased dramatically throughout 2009. Although the rate of provisioning edged down in the final quarter of last year, consistent with reduced charge-offs in some loan categories, some measures of reserve adequacy remained very low.

Despite the high levels of provisioning, the ROA at large banks increased from 0.04 percent in 2008 to 0.12 percent in 2009 . The improvement in profitability was due mainly to a rebound in these banks' 
noninterest income. In particular, trading revenue at large banks was boosted by significant improvements in financial markets throughout the year, including higher equity prices and lower interest rates on corporate bonds and other securities. In addition, relative to 2008, less noninterest expense, smaller losses on securities held in investment accounts, and improvements in net interest income supported earnings for the 100 largest banks. The improvement in net interest income was attributable to significant inflows of relatively low-cost core deposits, allowing banks to run off their more expensive managed liabilities. However, the improvement in profitability among the largest institutions was not uniform (figure 26, top panel). Forty-three of the top 100 banks-accounting for about 35 percent of the assets of such banksincurred losses, compared with 35 of the top 100 banks in 2008.

In contrast, the fourth quarter of 2009 marked the sixth consecutive quarter of losses at small and

26. Distribution of return on assets at commercial banks, by size of bank and by percentage of assets at all banks in each size category, 2008-09

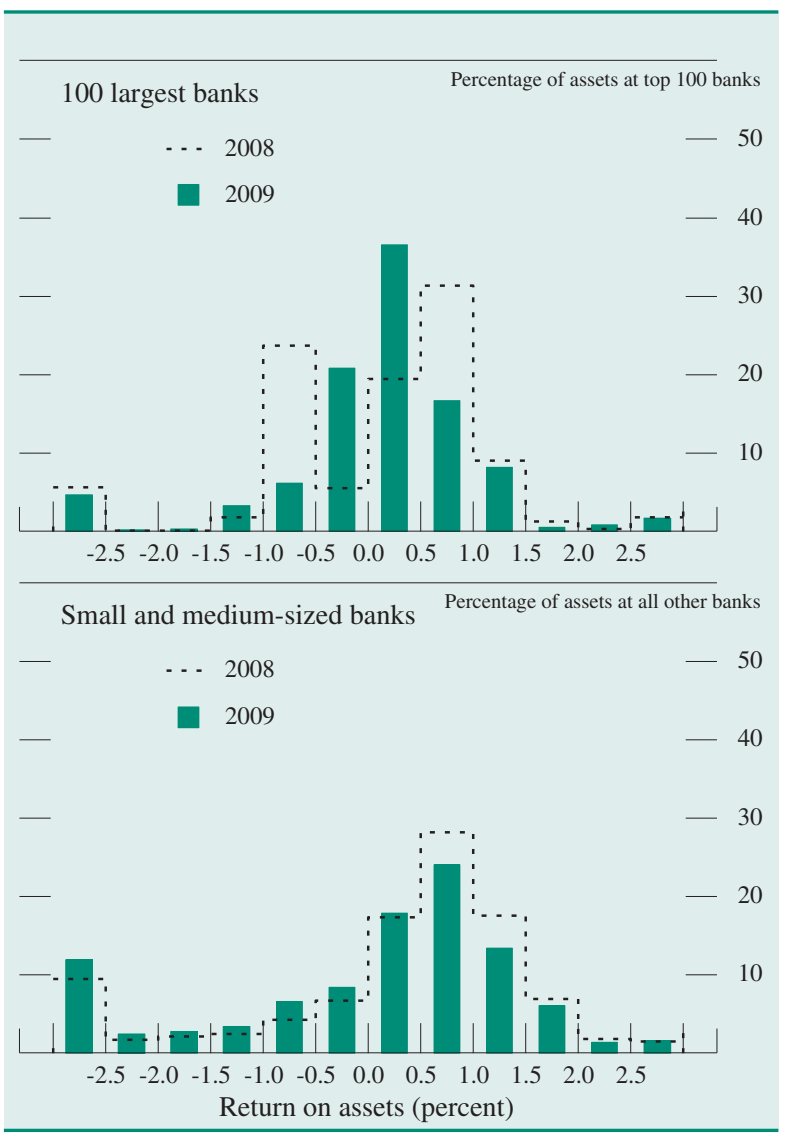

Note: Assets are deflated by a gross domestic product price deflator. For the definition of bank size, see the general note on the first page of the main text. medium-sized banks. ROA for such banks fell to negative 0.29 percent in 2009 from 0.10 percent in the previous year. The modest leftward shift in the distribution of ROA for such banks in 2009 reflects a deterioration in profitability for the group as a whole (figure 26, bottom panel). The fraction of small and medium-sized banks that incurred annual losses increased to about 30 percent in 2009, up from 23 percent in 2008. These institutions accounted for about 36 percent of assets at all small and medium-sized banks.

Several factors contributed to the weaker performance of smaller banks relative to larger ones. Smaller banks are not active in the capital market activities that provided a substantial source of revenue for large banks. In addition, smaller banks are relatively more exposed to the deterioration in loan quality, as loans compose a higher percentage of their assets. On the cost side, smaller banks could not substitute additional core deposits for managed liabilities to the same degree as large banks, as smaller banks already relied significantly on low-cost deposits for funding.

\section{Interest Income and Expense}

Overall, banks earned an average of 4.62 percent on their interest-earning assets in 2009, down from 5.72 percent in the previous year. The decline was due partly to large compositional shifts in banks' assets from loans to securities, an asset class that typically carries lower average interest rates. Indeed, the average effective interest rate on loans last year was 5.54 percent, while the rate on securities was significantly lower at 4.15 percent. However, the effective interest rate earned on loans net of provisioning fell sharply to just 2.10 percent, an unusually low rate of return by historical standards. The deterioration in loan quality also significantly reduced banks' interest income, as large fractions of loans that had yet to be charged off moved to nonaccrual status.

Meanwhile, consistent with the extended period of accommodative monetary policy, the average interest rate that banks paid on their interest-bearing liabilities fell steeply again, from 2.53 percent in 2008 to 1.30 percent in 2009. However, banks' use of substantial inflows of core deposits to pay down more costly managed liabilities was also an important factor in the decline. Core deposits are an attractive source of funding for banks because they tend to be fairly stable, as well as carry relatively low interest costs compared with managed liabilities. Most of the increase in core deposits last year came in the form of savings deposits, for which the effective interest rate 
27. Net interest margin and core deposits as a percentage of total assets, by size of bank, 1990-2009

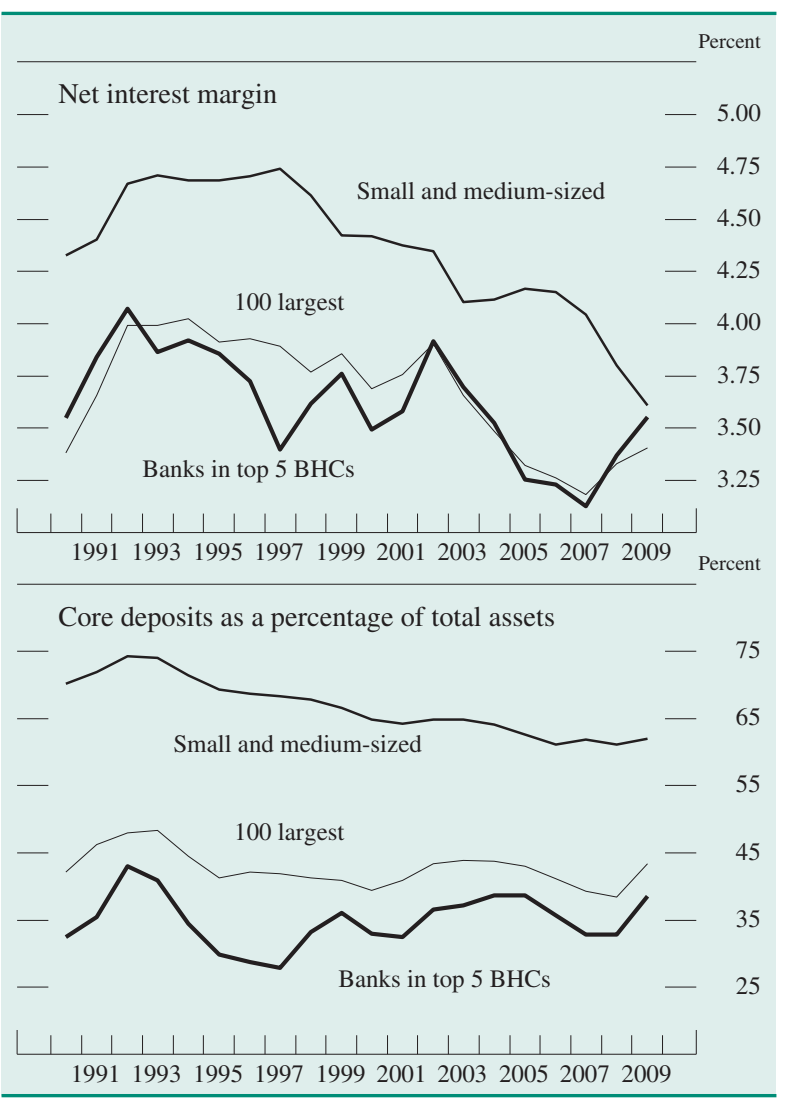

Note: The data are annual. Net interest margin is net interest income divided by average interest-earning assets. Core deposits consist of transaction deposits, savings deposits, and small time deposits. For the definition of bank size, see the general note on the first page of the main text; for the definition of the top five bank holding companies (BHCs), see text note 19 .

paid in 2009, measured by interest paid on such accounts relative to their average balances, was historically low at about 0.50 percent, down from 1.24 percent in 2008.

On balance, the industry-wide net interest margin was little changed in 2009 despite the reported widening of spreads for many types of new loans over banks' cost of funds, as noted in the SLOOS, and evidence of wider spreads on newly originated commercial and industrial loans from the Survey of Terms of Business Lending, possibly due to a large fraction of loans moving to nonaccrual status. However, the net interest margin for the largest banks improved noticeably over the past two years: For banks in the top five BHCs, net interest margins increased from 3.13 percent in 2007 to 3.55 percent in 2009 (figure 27, top panel). These institutions benefited the most from the decrease in funding costs associated with shedding higher-cost managed liabilities in favor of core deposits. Indeed, core deposits at banks in the top five BHCs jumped from less than 33 percent of average consolidated assets in 2008 to almost 39 percent in 2009 (figure 27, bottom panel). In addition, the substantial increase in equity capital at large organizations, though accounting for a small percentage of assets, also boosted net interest margins, as neither common nor preferred dividends are included in banks' interest expense.

In contrast, core deposits at small and mediumsized banks have been relatively stable over the past few years, averaging just above 60 percent of assets since 2006. The net interest margins at small and medium-sized banks decreased from 3.80 percent in 2008 to 3.61 percent in 2009 , as the drop in their asset yields exceeded the decline in the rates they paid on their liabilities.

\section{Noninterest Income and Expense}

Total noninterest income rebounded in 2009 to 2.07 percent of average assets. Most of the improvement was due to trading revenue at large banks returning to pre-crisis levels (figure 28, top panel). However, large banks' noninterest income was also boosted by a significant increase in income from net servicing fees and a substantial rise in the fair value of financial instruments accounted for under a fair value option as conditions in financial markets improved. ${ }^{23}$ These improvements at large banks were offset somewhat by a sizable drop in net securitization income and a small decline in income from deposit fees. Income from fiduciary activities also decreased, largely because of a sharp drop in the first quarter of 2009 as assets under management and the number of accounts at bank trust departments fell in the wake of the decline in stock prices. In contrast, noninterest income at small and medium-sized banks inched down last year to 1.34 percent of average assets, primarily because they also suffered from the decrease in income from fiduciary activities (figure 28, middle panel).

The divergent pattern of noninterest income between the large and the other banks mostly reflected the different composition of their financial intermediation activities. Trading revenue, net servicing fees, card interchange fees, and net securitization income composed less than 13 percent of small and mediumsized banks' noninterest income in 2009, compared

23. Some of the increase in the fair value of financial instruments may have been related to the new fair value guidance that was issued by the Financial Accounting Standards Board in April 2009 (FASB Staff Position FAS 157-e), which reduced the emphasis on "last transaction price" when markets are not active and transactions are likely to be forced or distressed. Generally, larger banks have tended to adopt the fair value option more widely than smaller banks. 
with about 35 percent for large banks. For large banks, trading revenue was boosted to pre-crisis levels by significant improvements in income from interest rate and credit exposures as conditions in financial markets improved (figure 28, bottom panel). The increase in net servicing fees-which include income from servicing mortgages, credit cards, and other off-balance-sheet assets, as well as changes in the fair value of such servicing rights - was partly a consequence of the consolidation of some large thrift

28. Noninterest income, and selected components, as a proportion of total assets, by size of bank, 2002-09

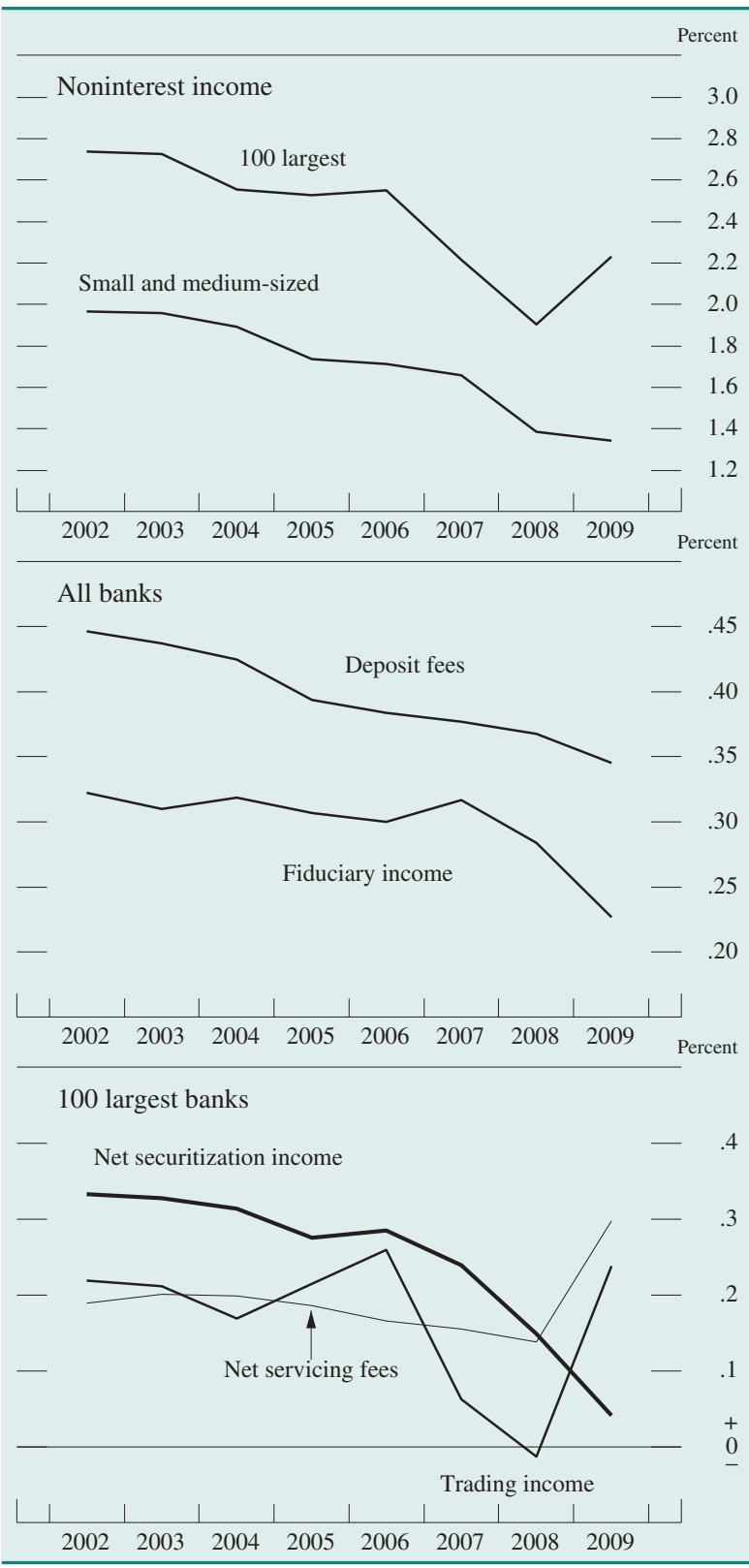

NoTE: The data are annual. For the definition of bank size, see the general note on the first page of the main text. institutions into the banking sector in the second and fourth quarters of 2009. Further, large banks reportedly sold sizable amounts of seasoned residential mortgage loans to the government-sponsored enterprises last year, and some may have retained servicing rights to those loans. While bankcard and credit card interchange fees continued to be an important source of noninterest income for large banks, net securitization income fell rapidly for the second consecutive year because of relatively subdued securitization activity. ${ }^{24}$ Other noninterest income items not mentioned separately already made up about 35 percent of noninterest income for the industry as a whole. $^{25}$

Banks' noninterest expense edged down to 3 percent of average assets in 2009 (figure 29, top panel). Salaries, wages, and employee benefits composed about 43 percent of noninterest expense, a figure that continues to be fairly low by historical standards. Among other noninterest expense items, net expenses of premises and fixed assets (excluding mortgage interest) continued to account for about 12 percent of noninterest expense. Goodwill impairment charges decreased from more than $\$ 26$ billion in 2008 to about $\$ 10$ billion in 2009.26 That improvement was offset, however, by rising FDIC assessment fees, which jumped to about $\$ 17$ billion in 2009 from slightly more than $\$ 1$ billion in 2008 (figure 29, bottom panel); those fees were exceptionally elevated in the second quarter of 2009, when the FDIC levied a special assessment fee in order to replenish the Deposit Insurance Fund (DIF) because of the growing number of bank failures. In the second half of 2009, the FDIC raised its estimated cost of bank failures and required banks to prepay regular assessments through 2012, with higher assessment rates applied for 2011 and 2012, in order to

24. Such income is composed of net gains and losses on assets sold in the bank's own securitization transactions net of transaction coststhis includes unrealized losses (and recoveries of unrealized losses) on loans and leases held for sale in the bank's own securitization transactions and fee income from securitizations, securitization conduits, and structured finance vehicles.

25. These other items include fees and commissions from securities brokerage, investment banking, advisory services, securities underwriting, and annuity sales; underwriting income from insurance and reinsurance activities; venture capital revenue; net gains and losses on sales of assets excluding securities; and other noninterest items. Items reported separately already are deposit fees, net servicing fees, fiduciary income, trading revenue, card interchange fees, the net change in the fair value of financial instruments, and net securitization income.

26. Banks incur goodwill impairment losses when the market value of their business segments (or reporting units) drops below the fair value recorded by the company. Companies must test for impairment of goodwill annually or when events occur that would likely reduce the fair value of a business segment (or reporting unit) below the carrying value. Assets are written down when considered overvalued compared with the market value - that is, the amount that a potential (or actual) acquirer would be willing to pay (or had paid) for the assets. 
29. Noninterest expense and selected components, and other selected components of noninterest expense, as a proportion of total assets, 2002-09

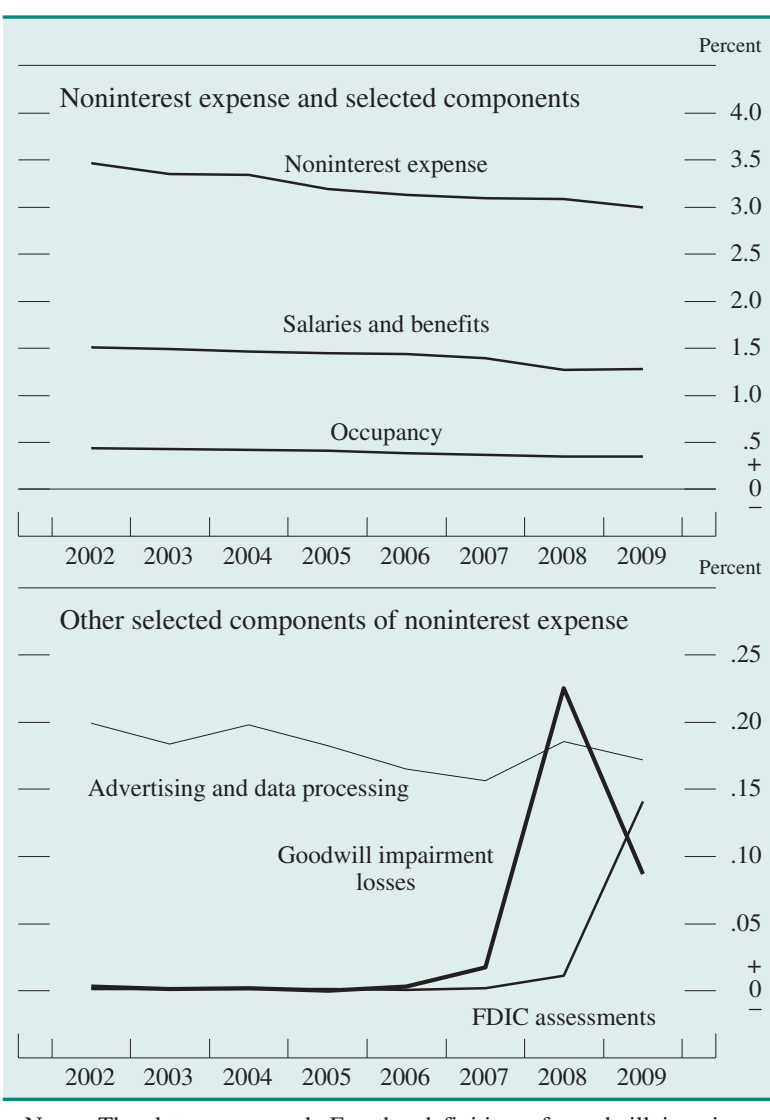

Note: The data are annual. For the definition of goodwill impairment losses, see text note 26. FDIC is the Federal Deposit Insurance Corporation.

shore up the DIF. This prepayment was not considered to be noninterest expense for 2009 , but rather was booked as a prepaid asset to be expensed smoothly over the next three years. According to the FDIC, these prepayments totaled $\$ 46$ billion for all FDIC-insured institutions. Banks were able to reduce expenses in other noninterest categories, which include data processing expenses, advertising and marketing costs, and other items. ${ }^{27}$

\section{INTERNATIONAL OPERATIONS \\ OF U.S. COMMERCIAL BANKS}

The share of U.S. bank assets booked in foreign offices edged down from about $121 / 2$ percent at yearend 2008 to just less than $121 / 4$ percent at year-end 2009. Assets booked abroad remained highly concentrated among the largest banks. Commercial banks returned to profitability on their international opera-

27. Other items include amortization expense and impairment losses for intangible assets besides goodwill, as well as other noninterest expense items. tions in 2009, though losses were reported on domestic operations for the first time since at least 1985. However, profits at foreign offices would have been negative and those at domestic offices positive, as was the case in 2008, had there not been a large reduction in internal allocations of income and expense applicable to foreign offices at one large bank. Before such allocations and restructuring activity for the industry as a whole, net income from foreign offices as a percentage of average assets booked in foreign offices remained about the same as in 2008. More specifically, large increases in provisioning for loans and leases held at banks' foreign offices and a fall in noninterest income were offset by significantly smaller noninterest expense and a return to positive realized gains in investment account securities.

Banks' total exposures to foreign economies through lending and derivatives activities increased in 2009 , as two investment banks with large foreign exposures became BHCs and were added to the Federal Financial Institutions Examination Council's Country Exposure Lending Survey (table 3). Without the change in the sample of banks, such foreign exposures would have continued to decline. The vast majority of U.S. banks' cross-border lending and derivatives outstanding - in dollar terms-remained in the advanced foreign economies at the end of 2009. ${ }^{28}$ Lending and derivatives activities outstanding in Asia were about 12 percent of total foreign exposure, or 35 percent of total tier 1 capital of the banks in the survey. Lending and derivatives exposures to the Latin American and the Caribbean regions and such exposures to a selected group of European Union countries (Greece, Ireland, Italy, Portugal, and Spain) were both about 25 percent of total tier 1 capital.

\section{DEVELOPMENTS IN EARLY 2010}

U.S. economic activity continued to recover in the first quarter of 2010, and financial market conditions remained broadly supportive of economic recovery. ${ }^{29}$ In particular, household spending expanded moderately, while business spending on equipment and software rose significantly. The equity and bond markets continued to be an important source of funding for large corporations. Treasury yields, interest rates on business loans, and mortgage rates

28. The advanced foreign economies include Australia, Austria, Belgium, Canada, Denmark, Finland, France, Germany, Greece, Iceland, Ireland, Israel, Italy, Japan, Luxembourg, the Netherlands, New Zealand, Norway, Portugal, South Africa, Spain, Sweden, Switzerland, Turkey, and the United Kingdom.

29. This section reflects information available through mid-April. 
3. Exposure of U.S. banks to selected economies at year-end relative to tier 1 capital, 1998-2009 Percent

\begin{tabular}{|c|c|c|c|c|c|c|c|c|c|c|c|c|}
\hline \multirow{2}{*}{ Year } & \multicolumn{4}{|c|}{ Asia } & \multicolumn{3}{|c|}{ Latin America and the Caribbean } & \multirow{2}{*}{$\begin{array}{l}\text { Eastern } \\
\text { Europe }\end{array}$} & \multirow{2}{*}{$\begin{array}{c}\text { G-10 and } \\
\text { Switzerland }^{1}\end{array}$} & \multirow{2}{*}{$\begin{array}{l}\text { Non-G-10 } \\
\text { developed } \\
\text { countries }^{2}\end{array}$} & \multirow{2}{*}{ Total } & \multirow{2}{*}{$\begin{array}{c}\text { Mемо } \\
\text { Selected } \\
\text { EU } \\
\text { countries }\end{array}$} \\
\hline & All & China & India & Korea & All & Mexico & Brazil & & & & & \\
\hline 1998 & 28.2 & 1.0 & 2.2 & 7.1 & 42.9 & 9.9 & 11.3 & 3.5 & 182.5 & 37.1 & 294.3 & 29.7 \\
\hline 2000 & 24.0 & .8 & 2.6 & 6.4 & 37.9 & 9.1 & 11.2 & 4.4 & 174.6 & 32.8 & 273.7 & 26.9 \\
\hline 2002 & 21.9 & .9 & 2.7 & 5.8 & 38.9 & 20.8 & 8.4 & 5.5 & 172.1 & 21.3 & 259.8 & 23.9 \\
\hline 2004 & 32.2 & 1.4 & 4.2 & 15.0 & 31.8 & 16.6 & 6.5 & 6.1 & 198.2 & 37.2 & 305.4 & 25.7 \\
\hline 2006 & 34.7 & 4.1 & 6.1 & 13.6 & 30.8 & 16.8 & 5.7 & 6.5 & 174.7 & 38.5 & 285.1 & 23.2 \\
\hline 2007 & 44.6 & 4.5 & 9.8 & 14.4 & 35.6 & 17.2 & 8.2 & 9.0 & 219.3 & 48.3 & 356.6 & 27.0 \\
\hline 2008 & 30.8 & 3.4 & 6.1 & 10.7 & 25.5 & 12.9 & 5.0 & 5.4 & 166.3 & 35.3 & 263.3 & 20.0 \\
\hline 2009 & 35.2 & 6.4 & 6.1 & 11.3 & 25.0 & 12.0 & 7.0 & 4.6 & 198.1 & 39.9 & 302.8 & 25.4 \\
\hline \multicolumn{13}{|c|}{$\begin{array}{l}\text { Мемо } \\
\text { Total exposure } \\
\text { (billions of } \\
\text { dollars) }\end{array}$} \\
\hline $1998 \ldots$ & 69.1 & 2.3 & 5.4 & 17.3 & 105.0 & 24.1 & 27.6 & 8.5 & 446.3 & 90.8 & 719.6 & 72.5 \\
\hline $2000 \ldots$ & 68.0 & 2.2 & 7.5 & 18.1 & 107.3 & 25.7 & 31.6 & 12.3 & 494.6 & 93.0 & 775.3 & 76.3 \\
\hline 2002 & 69.5 & 2.7 & 8.7 & 18.4 & 123.5 & 66.2 & 26.6 & 17.5 & 546.5 & 67.7 & 824.7 & 75.9 \\
\hline 2004 . & 125.8 & 5.3 & 16.3 & 58.7 & 124.4 & 65.2 & 25.5 & 23.8 & 775.7 & 145.5 & $1,195.4$ & 100.6 \\
\hline 2006 . & 190.5 & 22.7 & 33.6 & 74.8 & 168.9 & 92.5 & 31.5 & 35.5 & 959.1 & 211.2 & $1,565.2$ & 127.1 \\
\hline 2007 & 249.8 & 25.5 & 54.9 & 80.8 & 199.3 & 96.1 & 46.2 & 50.2 & $1,229.0$ & 270.5 & $1,998.8$ & 151.6 \\
\hline 2008 & 217.4 & 24.3 & 43.1 & 75.3 & 179.7 & 90.7 & 35.6 & 37.9 & $1,172.9$ & 248.6 & $1,856.5$ & 141.0 \\
\hline 2009 & 328.4 & 59.5 & 56.8 & 105.2 & 233.2 & 111.4 & 65.6 & 42.6 & $1,846.2$ & 371.9 & $2,822.3$ & 236.8 \\
\hline
\end{tabular}

NotE: Exposures consist of lending and derivatives exposures for crossborder and local-office operations. Respondents may file information on one bank or on the bank holding company as a whole. For the definition of tier 1 capital, see text note 21 .

The 2009 data cover 69 banks (which include two large, newly formed bank holding companies) with a total of $\$ 932.1$ billion in tier 1 capital. The 2008 data covered 68 banks with a total of $\$ 705.1$ billion in tier 1 capital.

1. The G-10 (Group of Ten) countries are Belgium, Canada, France, Germany, Italy, Japan, Luxembourg, the Netherlands, Sweden, and the United Kingdom.

remained low by historical standards, partly due to accommodative monetary policy. The Federal Open Market Committee continued to maintain a target range for the federal funds rate of 0 to $1 / 4$ percent. Financial markets showed little effect from the end of the Federal Reserve's purchases of agency mortgagebacked securities and agency debt and the expiration of most of the Federal Reserve's emergency credit facilities. However, unemployment remained elevated, investment in nonresidential structures declined further, and home sales generally remained low.

Amid tight credit conditions and reportedly weak demand, loans to both businesses and households continued to decline during the first three months of 2010. Commercial and industrial loans contracted further as spreads of interest rates on such loans over comparable-maturity market instruments climbed again in the first quarter. Commercial real estate loans also posted a substantial decline, which reflected weak investment in nonresidential structures. Resi-
2. The non-G-10 developed countries include Australia, Austria, Denmark, Finland, Greece, Iceland, Ireland, Israel, New Zealand, Norway, Portugal, South Africa, Spain, and Turkey.

3. The selected European Union (EU) countries consist of Greece, Ireland, Italy, Portugal, and Spain.

Source: Federal Financial Institutions Examination Council, Statistical Release E.16, "Country Exposure Lending Survey" (www.ffiec.gov/E16.htm).

dential real estate loans also ran off, likely owing importantly to greater securitizations of mortgages to the government-sponsored enterprises and sluggish home sales, while credit card balances continued to fall, perhaps partly in response to further increases in interest rates on credit cards.

Bank profitability improved significantly in the first quarter of 2010 as many banks reported tentative improvements in credit quality. In particular, the four largest bank holding companies recorded profits in the first quarter of 2010, as trading revenue and lower loss provisioning boosted earnings. Indeed, the fairly broad-based decline in loss provisioning also contributed to improved earnings at many regional banks. Nevertheless, regional and smaller banks continued to struggle with profitability as credit losses on core lending operations remained high. Moreover, failures of smaller banks continued in 2010 at about the same pace as 2009, driven largely by credit losses on commercial real estate lending. 
A.1. Portfolio composition, interest rates, and income and expense, U.S. banks, 2000-09

A. All banks

\begin{tabular}{|c|c|c|c|c|c|c|c|c|c|c|}
\hline Item & 2000 & 2001 & 2002 & 2003 & 2004 & 2005 & 2006 & 2007 & 2008 & 2009 \\
\hline & \multicolumn{10}{|c|}{ Balance sheet items as a percentage of average net consolidated assets } \\
\hline Interest-earning assets ${ }^{1} \ldots$ & 87.13 & 86.49 & 86.42 & 86.08 & 86.90 & 86.82 & 86.86 & 86.94 & 85.28 & 85.71 \\
\hline Loans and leases (net)......... & 60.48 & 58.95 & 57.83 & 56.88 & 56.98 & 57.88 & 58.26 & 58.37 & 56.73 & 53.96 \\
\hline Commercial and industrial & 17.16 & 16.08 & 14.07 & 12.18 & 11.06 & 11.17 & 11.42 & 11.84 & 12.08 & 10.77 \\
\hline U.S. addressees ......... & 14.67 & 13.69 & 12.04 & 10.48 & 9.52 & 9.64 & 9.73 & 9.86 & 10.12 & 9.20 \\
\hline Foreign addressees . & 2.49 & 2.39 & 2.04 & 1.70 & 1.54 & 1.53 & 1.70 & 1.98 & 1.96 & 1.57 \\
\hline Consumer ............ & 9.38 & 9.23 & 9.35 & 9.06 & 9.18 & 9.12 & 8.53 & 8.43 & 8.33 & 8.06 \\
\hline Credit card. . & 3.52 & 3.69 & 3.78 & 3.55 & 3.87 & 4.06 & 3.73 & 3.72 & 3.68 & 3.59 \\
\hline Installment and other. & 5.87 & 5.55 & 5.57 & 5.51 & 5.31 & 5.06 & 4.80 & 4.71 & 4.65 & 4.47 \\
\hline Real estate ............ & 27.04 & 27.10 & 28.39 & 29.91 & 30.77 & 32.40 & 33.19 & 33.37 & 31.96 & 32.02 \\
\hline In domestic offices $\ldots \ldots \ldots \ldots \ldots \ldots$ & 26.49 & 26.60 & 27.91 & 29.45 & 30.24 & 31.84 & 32.61 & 32.76 & 31.35 & 31.50 \\
\hline Construction and land development . & 2.51 & 2.85 & 2.98 & 2.99 & 3.26 & 3.90 & 4.73 & 5.05 & 4.73 & 3.99 \\
\hline Farmland $\ldots \ldots \ldots \ldots \ldots \ldots \ldots \ldots$ & .56 & .55 & .56 & .54 & .54 & .54 & .53 & .53 & .52 & .55 \\
\hline One- to four-family residential. & 14.96 & 14.67 & 15.40 & 16.96 & 17.42 & 18.26 & 18.23 & 18.31 & 17.29 & 17.59 \\
\hline Home equity ............... & 1.96 & 2.18 & 2.80 & 3.40 & 4.34 & 4.95 & 4.71 & 4.49 & 4.60 & 5.07 \\
\hline Other ............. & 13.00 & 12.49 & 12.60 & 13.57 & 13.08 & 13.31 & 13.51 & 13.82 & 12.70 & 12.52 \\
\hline Multifamily residential. & .99 & .97 & 1.02 & 1.05 & 1.06 & 1.08 & 1.06 & 1.04 & 1.10 & 1.30 \\
\hline Nonfarm nonresidential & 7.48 & 7.56 & 7.95 & 7.91 & 7.97 & 8.06 & 8.07 & 7.84 & 7.70 & 8.07 \\
\hline In foreign offices ............ & .54 & .50 & .48 & .46 & .53 & .56 & .58 & .60 & .61 & .53 \\
\hline \multicolumn{11}{|l|}{ To depository institutions and } \\
\hline $\begin{array}{l}\text { acceptances of other banks } \\
\text { Foreign governments }\end{array}$ & 1.87 & 1.83 & 1.87 & 1.98 & 2.11 & 1.73 & 1.65 & 1.21 & 1.19 & 1.01 \\
\hline $\begin{array}{l}\text { Foreign governments ... } \\
\text { Agricultural production . }\end{array}$ & .12 & .10 & .09 & .08 & .08 & .06 & .04 & .03 & .02 & .02 \\
\hline $\begin{array}{l}\text { Agricultural production . } \\
\text { Other loans. }\end{array}$ & .78 & .75 & .70 & .63 & .59 & .56 & .55 & .52 & .49 & .49 \\
\hline $\begin{array}{l}\text { Other loans................... } \\
\text { Lease-financing receivables }\end{array}$ & 2.58 & 2.34 & 2.06 & 2.00 & 2.35 & 2.09 & 2.19 & 2.48 & 2.64 & 2.26 \\
\hline Lease-financing receivables ...... & 2.63 & 2.58 & 2.44 & 2.11 & 1.79 & 1.58 & 1.43 & 1.23 & 1.07 & .94 \\
\hline LESS: Unearned income on loans . & -.05 & -.04 & -.05 & -.04 & -.04 & -.03 & -.03 & -.02 & -.02 & -.02 \\
\hline Less: Loss reserves ${ }^{2} \ldots \ldots \ldots \ldots$ & -1.02 & -1.04 & -1.11 & -1.03 & -.91 & -.79 & -.71 & -.70 & -1.03 & -1.58 \\
\hline Securities............ & 20.02 & 19.53 & 21.27 & 21.90 & 22.57 & 22.04 & 21.32 & 20.77 & 19.27 & 20.39 \\
\hline Investment account & 17.59 & 16.82 & 18.30 & 18.97 & 18.99 & 17.87 & 16.89 & 15.41 & 14.13 & 16.62 \\
\hline Debt............... & 16.93 & 16.48 & 17.99 & 18.72 & 18.79 & 17.71 & 16.73 & 15.23 & 13.95 & 16.36 \\
\hline U.S. Treasury .............. & 1.66 & .85 & .78 & .90 & .89 & .62 & .47 & .32 & .24 & .52 \\
\hline $\begin{array}{l}\text { U.S. government agency and } \\
\text { corporation obligations } \ldots \ldots \ldots \ldots\end{array}$ & 10.31 & 10.08 & 11.46 & 12.26 & 12.37 & 11.51 & \multicolumn{3}{|c|}{ U.S. government agency and } & 9.32 \\
\hline Government-backed mortgage pools & 4.75 & $\begin{array}{r}10.00 \\
5.13\end{array}$ & $\begin{array}{r}11.40 \\
6.09\end{array}$ & $\begin{array}{r}12.20 \\
6.75\end{array}$ & $\begin{array}{r}12.31 \\
7.13\end{array}$ & $\begin{array}{r}11.31 \\
6.78\end{array}$ & $\begin{array}{r}10.03 \\
6.43\end{array}$ & $\begin{array}{l}9.32 \\
5.82\end{array}$ & $\begin{array}{l}8.14 \\
5.47\end{array}$ & $\begin{array}{l}9.32 \\
6.14\end{array}$ \\
\hline Collateralized mortgage obligations. & 1.92 & 1.95 & 2.35 & 2.34 & 2.01 & 1.80 & 1.58 & 1.34 & 1.27 & 1.52 \\
\hline 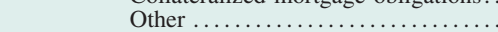 & 3.63 & 2.99 & 3.02 & 3.17 & 3.22 & 2.93 & 2.65 & 2.16 & 1.40 & 1.66 \\
\hline State and local government........... & 1.52 & 1.49 & 1.49 & 1.48 & 1.41 & 1.36 & 1.34 & 1.34 & 1.20 & 1.27 \\
\hline Private mortgage-backed securities... & .95 & 1.09 & 1.25 & 1.30 & 1.41 & 1.76 & 1.89 & 2.15 & 2.10 & 1.88 \\
\hline Other. $\ldots \ldots \ldots \ldots \ldots \ldots \ldots \ldots$ & 2.48 & 2.98 & 3.01 & 2.78 & 2.72 & 2.47 & 2.37 & 2.10 & 2.28 & 3.36 \\
\hline Equity $\ldots \ldots \ldots \ldots \ldots \ldots \ldots \ldots \ldots \ldots \ldots$ & .66 & .34 & .31 & .25 & .20 & .16 & .16 & .18 & .18 & .26 \\
\hline Trading account $\ldots \ldots \ldots \ldots \ldots \ldots \ldots \ldots$ & 2.43 & 2.72 & 2.97 & 2.93 & 3.59 & 4.17 & 4.43 & 5.36 & 5.13 & 3.77 \\
\hline Gross federal funds sold and reverse RPs. & 4.12 & 5.11 & 4.81 & 4.85 & 4.58 & 4.75 & 5.30 & 5.49 & 6.03 & 4.54 \\
\hline Balances at depositories 1 . ............. & 2.52 & 2.90 & 2.52 & 2.46 & 2.76 & 2.14 & 1.98 & 2.30 & 3.25 & 6.82 \\
\hline Noninterest-earning assets ${ }^{1} \ldots \ldots \ldots \ldots \ldots \ldots$ & 12.87 & 13.51 & 13.58 & 13.92 & 13.10 & 13.18 & 13.14 & 13.06 & 14.72 & 14.29 \\
\hline Revaluation gains held in trading accounts .. & 2.28 & 2.37 & 2.42 & 2.70 & 2.19 & 1.82 & 1.64 & 1.73 & 2.83 & 2.78 \\
\hline 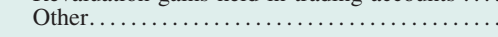 & 10.58 & 11.14 & 11.16 & 11.22 & 10.91 & 11.36 & 11.51 & 11.33 & 11.90 & 11.51 \\
\hline Liabilities........ & 91.58 & 91.25 & 90.85 & 90.96 & 90.57 & 89.91 & 89.84 & 89.78 & 90.07 & 89.50 \\
\hline Core deposits ............... & 46.52 & 47.07 & 48.98 & 49.18 & 48.56 & 47.52 & 45.56 & 43.89 & 42.72 & 46.92 \\
\hline Transaction deposits .. & 11.07 & 10.36 & 10.06 & 9.73 & 9.10 & 8.46 & 7.45 & 6.43 & 6.16 & 6.90 \\
\hline Demand deposits ............... & 8.61 & 8.00 & 7.67 & 7.26 & 6.58 & 6.16 & 5.41 & 4.66 & 4.53 & 5.06 \\
\hline Other checkable deposits ............. & 2.46 & 2.36 & 2.39 & 2.47 & 2.52 & 2.30 & 2.04 & 1.77 & 1.63 & 1.84 \\
\hline Savings deposits (including MMDAs) .... & 22.43 & 24.53 & 28.13 & 30.12 & 31.19 & 30.83 & 29.49 & 28.21 & 27.04 & 29.98 \\
\hline Small time deposits .................. & 13.01 & 12.18 & 10.80 & 9.33 & 8.27 & 8.23 & 8.62 & 9.26 & 9.51 & 10.04 \\
\hline Managed liabilities $^{3} \ldots \ldots \ldots \ldots \ldots \ldots \ldots$ & 38.83 & 37.42 & 35.05 & 34.61 & 35.69 & 36.25 & 38.29 & 39.85 & 41.08 & 37.09 \\
\hline Large time deposits... & 8.77 & 8.89 & 8.30 & 8.09 & 8.00 & 9.11 & 10.07 & 9.13 & 9.13 & 8.32 \\
\hline Deposits booked in foreign offices... & 11.43 & 10.66 & 9.42 & 9.38 & 10.25 & 10.39 & 11.18 & 12.81 & 13.09 & 12.56 \\
\hline Subordinated notes and debentures ...... & 1.37 & 1.43 & 1.40 & 1.33 & 1.30 & 1.34 & 1.40 & 1.55 & 1.51 & 1.39 \\
\hline Gross federal funds purchased and RPs... & 7.83 & 7.95 & 7.77 & 7.75 & 7.24 & 7.05 & 7.53 & 7.06 & 6.98 & 6.05 \\
\hline 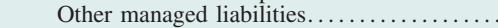 & 9.44 & 8.49 & 8.16 & 8.06 & 8.91 & 8.37 & 8.11 & 9.31 & 10.38 & 8.77 \\
\hline Revaluation losses held in trading accounts... & 2.29 & 2.21 & 2.09 & 2.30 & 1.95 & 1.67 & 1.51 & 1.59 & 2.27 & 1.98 \\
\hline 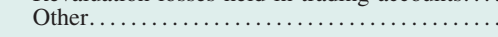 & 3.94 & 4.54 & 4.73 & 4.87 & 4.36 & 4.47 & 4.47 & 4.44 & 4.01 & 3.51 \\
\hline Capital account & 8.42 & 8.75 & 9.15 & 9.04 & 9.43 & 10.09 & 10.16 & 10.22 & 9.93 & 10.50 \\
\hline \multicolumn{11}{|l|}{ Мемо } \\
\hline Commercial real estate loans ${ }^{4}$. . & 11.58 & 12.09 & 12.57 & 12.47 & 12.78 & 13.52 & 14.35 & 14.47 & 14.10 & 13.91 \\
\hline Other real estate owned ${ }^{5} \ldots \ldots$. & .05 & .05 & .06 & .06 & .06 & .04 & .05 & .07 & .13 & .28 \\
\hline Mortgage-backed securities ............ & 7.63 & 8.17 & 9.69 & 10.39 & 10.56 & 10.33 & 9.89 & 9.31 & 8.84 & 9.55 \\
\hline Federal Home Loan Bank advances .... & n.a. & 2.89 & 3.17 & 3.19 & 3.07 & 3.04 & 3.07 & 3.66 & 4.45 & 3.77 \\
\hline Balances at the Federal Reserve ${ }^{1} \ldots \ldots$. & .42 & .40 & .38 & .40 & .35 & .29 & .24 & .20 & 3.44 & 4.14 \\
\hline Interest-earning $\ldots \ldots \ldots \ldots \ldots \ldots \ldots$ & n.a. & n.a. & n.a. & n.a. & n.a. & n.a. & n.a. & n.a. & 3.00 & 4.14 \\
\hline & .42 & .40 & .38 & .40 & .35 & .29 & .24 & .20 & .44 & n.a. \\
\hline \multicolumn{11}{|l|}{ Interest-earning balances at depositories } \\
\hline other than the Federal Reserve ..... & 2.52 & 2.90 & 2.52 & 2.46 & 2.76 & 2.14 & 1.98 & 2.30 & 2.69 & 2.68 \\
\hline $\begin{array}{l}\text { Average net consolidated assets } \\
\text { (billions of dollars) .............. }\end{array}$ & 5,907 & 6,334 & 6,635 & 7,249 & 7,879 & 8,592 & 9,427 & 10,396 & 11,578 & 11,869 \\
\hline
\end{tabular}


A.1. Portfolio composition, interest rates, and income and expense, U.S. banks, 2000-09_Continued

A. All banks-Continued

\begin{tabular}{|c|c|c|c|c|c|c|c|c|c|c|}
\hline Item & 2000 & 2001 & 2002 & 2003 & 2004 & 2005 & 2006 & 2007 & 2008 & 2009 \\
\hline & \multicolumn{10}{|c|}{ Effective interest rate (percent) ${ }^{6}$} \\
\hline \multicolumn{11}{|l|}{ Rates earned } \\
\hline Interest-earning assets .... & 8.20 & 7.37 & 6.10 & 5.29 & 5.08 & 5.70 & 6.65 & 6.78 & 5.72 & 4.62 \\
\hline Taxable equivalent & 8.26 & 7.42 & 6.15 & 5.33 & 5.12 & 5.73 & 6.69 & 6.82 & 5.74 & 4.64 \\
\hline Loans and leases, gross ... & 9.00 & 8.15 & 6.89 & 6.15 & 5.91 & 6.52 & 7.55 & 7.54 & 6.39 & 5.54 \\
\hline Net of loss provisions & 8.33 & 7.15 & 5.84 & 5.47 & 5.47 & 6.09 & 7.18 & 6.69 & 3.90 & 2.10 \\
\hline Securities ................. & 6.47 & 6.04 & 4.95 & 3.96 & 3.86 & 4.18 & 4.71 & 5.02 & 4.86 & 4.15 \\
\hline Taxable equivalent & 6.65 & 6.22 & 5.10 & 4.10 & 3.99 & 4.30 & 4.83 & 5.14 & 4.94 & 4.23 \\
\hline Investment account ................ & 6.45 & 6.05 & 5.04 & 4.00 & 3.96 & 4.29 & 4.86 & 5.13 & 4.93 & 4.31 \\
\hline \multicolumn{11}{|l|}{$\begin{array}{l}\text { U.S. Treasury securities and U.S. } \\
\text { government agency obligations }\end{array}$} \\
\hline (excluding MBS) …........... & n.a. & 5.76 & 4.42 & 3.29 & 3.11 & 3.46 & 4.19 & 4.71 & 4.23 & 2.78 \\
\hline Mortgage-backed securities & n.a. & 6.45 & 5.44 & 4.24 & 4.38 & 4.60 & 5.10 & 5.29 & 5.21 & 4.86 \\
\hline Other .................... & n.a. & 5.60 & 4.74 & 4.08 & 3.76 & 4.23 & 4.76 & 5.02 & 4.58 & 3.94 \\
\hline Trading account $\ldots \ldots \ldots \ldots \ldots \ldots \ldots \ldots$ & 6.63 & 6.01 & 4.38 & 3.71 & 3.35 & 3.72 & 4.16 & 4.70 & 4.64 & 3.44 \\
\hline Gross federal funds sold and reverse RPs & 5.56 & 3.86 & 1.93 & 1.40 & 1.40 & 2.66 & 4.31 & 5.07 & 2.50 & .64 \\
\hline Interest-bearing balances at depositories ${ }^{1}$ & 6.48 & $\begin{array}{l}3.00 \\
4.01\end{array}$ & 2.79 & 2.09 & 1.98 & 3.70 & 5.10 & 5.13 & 3.23 & .04 \\
\hline \multicolumn{11}{|l|}{ Rates paid } \\
\hline Interest-bearing liabilities ... & 4.94 & 3.93 & 2.38 & 1.72 & 1.63 & 2.47 & 3.59 & 3.82 & 2.53 & 1.30 \\
\hline Interest-bearing deposits.. & 4.45 & 3.61 & 2.11 & 1.47 & 1.36 & 2.06 & 3.05 & 3.39 & 2.26 & 1.14 \\
\hline In foreign offices ..... & 5.61 & 3.94 & 2.38 & 1.62 & 1.72 & 2.77 & 3.92 & 4.23 & 2.47 & .69 \\
\hline In domestic offices............ & 4.17 & 3.54 & 2.06 & 1.44 & 1.29 & 1.91 & 2.85 & 3.18 & 2.20 & 1.25 \\
\hline Other checkable deposits .............. & 2.34 & 1.96 & 1.06 & .75 & .77 & 1.41 & 1.88 & 2.04 & 1.16 & .60 \\
\hline Savings deposits (including MMDAs) & 2.86 & 2.19 & 1.13 & .74 & .72 & 1.24 & 2.01 & 2.22 & 1.24 & .50 \\
\hline Large time deposits................. & 5.78 & 5.04 & 3.37 & 2.59 & 2.35 & 3.19 & 4.39 & 4.71 & 3.48 & 2.22 \\
\hline Other time deposits.................. & 5.69 & 5.43 & 3.70 & 2.88 & 2.56 & 3.14 & 4.11 & 4.72 & 3.83 & 2.79 \\
\hline \multirow{3}{*}{$\begin{array}{l}\text { Gross federal funds purchased and RPs } \\
\text { Other interest-bearing liabilities......... }\end{array}$} & 5.77 & 3.83 & 1.88 & 1.30 & 1.49 & 3.07 & 4.57 & 4.97 & 2.39 & .62 \\
\hline & 6.97 & 5.91 & 4.49 & 3.69 & 3.34 & 4.58 & 6.29 & 5.46 & 4.05 & 2.74 \\
\hline & \multicolumn{10}{|c|}{ Income and expense as a percentage of average net consolidated assets } \\
\hline Gross interest income... & 7.18 & 6.38 & 5.27 & 4.54 & 4.43 & 4.97 & 5.85 & 5.94 & 4.88 & 4.05 \\
\hline Taxable equivalent. & 7.22 & 6.42 & 5.31 & 4.58 & 4.46 & 5.00 & 5.88 & 5.97 & 4.91 & 4.07 \\
\hline Loans ............... & 5.53 & 4.92 & 4.06 & 3.55 & 3.42 & 3.82 & 4.48 & 4.47 & 3.68 & 3.10 \\
\hline 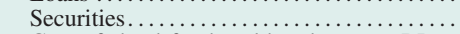 & 1.15 & 1.00 & .89 & .74 & .74 & .77 & .84 & .80 & .70 & .72 \\
\hline Gross federal funds sold and reverse RPs & .23 & .20 & .09 & .07 & .07 & .13 & .23 & .28 & .14 & .03 \\
\hline 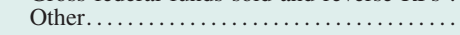 & .27 & .27 & .22 & .18 & .20 & .25 & .31 & .39 & .35 & .20 \\
\hline Gross interest expense ...... & 3.76 & 2.98 & 1.79 & 1.30 & 1.25 & 1.89 & 2.79 & 2.99 & 1.96 & 1.03 \\
\hline Deposits............................................ & 2.56 & 2.09 & 1.23 & .86 & .81 & 1.23 & 1.84 & 2.05 & 1.33 & .71 \\
\hline Gross federal funds purchased and RPs & .45 & .31 & .15 & .10 & .11 & .22 & .36 & .36 & .17 & .04 \\
\hline 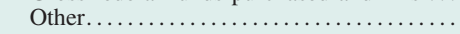 & .75 & .58 & .41 & .33 & .33 & .44 & .59 & .58 & .45 & .28 \\
\hline Net interest income..... & 3.41 & 3.40 & 3.48 & 3.24 & 3.17 & 3.07 & 3.05 & 2.95 & 2.93 & 3.02 \\
\hline Taxable equivalent. & 3.46 & 3.44 & 3.52 & 3.28 & 3.21 & 3.11 & 3.09 & 2.98 & 2.95 & 3.05 \\
\hline Loss provisions $^{7} \ldots \ldots$. . & .50 & .68 & .68 & .45 & .30 & .30 & .27 & .55 & 1.48 & 1.95 \\
\hline Noninterest income........... & 2.59 & 2.54 & 2.54 & 2.54 & 2.40 & 2.35 & 2.36 & 2.10 & 1.81 & 2.07 \\
\hline Service charges on deposits. & .40 & .42 & .45 & .44 & .42 & .39 & .38 & .38 & .37 & .35 \\
\hline Fiduciary activities.......... & .38 & .35 & .32 & .31 & .32 & .31 & .30 & .32 & .28 & .23 \\
\hline Trading revenue ........... & .21 & .20 & .16 & .16 & .13 & .17 & .20 & .05 & -.01 & .20 \\
\hline Interest rate exposures .............. & .08 & .09 & .08 & .07 & .03 & .05 & .05 & .04 & -.01 & .12 \\
\hline 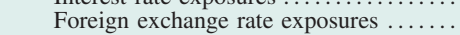 & .08 & .07 & .07 & .07 & .07 & .07 & .08 & .07 & .09 & .04 \\
\hline Other commodity and equity exposures. & .04 & .03 & .01 & .02 & .03 & .04 & .07 & .03 & .01 & .02 \\
\hline Credit exposures.............................. & n.a. & n.a. & n.a. & n.a. & n.a. & n.a. & n.a. & -.09 & -.11 & .01 \\
\hline Other................. & 1.61 & 1.57 & 1.60 & 1.63 & 1.53 & 1.48 & 1.48 & 1.36 & 1.16 & 1.30 \\
\hline Noninterest expense $\ldots \ldots \ldots \ldots \ldots \ldots \ldots$ & 3.66 & 3.57 & 3.47 & 3.36 & 3.34 & 3.19 & 3.13 & 3.09 & 3.09 & 3.00 \\
\hline Salaries, wages, and employee benefits & 1.51 & 1.49 & 1.51 & 1.50 & 1.46 & 1.44 & 1.44 & 1.39 & 1.27 & 1.28 \\
\hline Occupancy $\ldots \ldots \ldots \ldots \ldots \ldots \ldots \ldots \ldots \ldots \ldots \ldots \ldots$ & .45 & .44 & .44 & .43 & .42 & .41 & .39 & .37 & .35 & .35 \\
\hline Other............ & 1.70 & 1.64 & 1.51 & 1.43 & 1.46 & 1.34 & 1.30 & 1.33 & 1.46 & 1.37 \\
\hline Net noninterest expense ...... & 1.07 & 1.03 & .93 & .82 & .94 & .84 & .76 & .99 & 1.28 & .93 \\
\hline Gains on investment account securities ...... & -.04 & .07 & .10 & .08 & .04 & $*$ & -.01 & -.01 & -.14 & -.01 \\
\hline 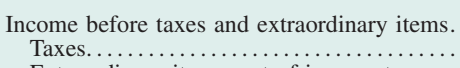 & $\begin{array}{r}1.81 \\
.63\end{array}$ & $\begin{array}{r}1.77 \\
.59\end{array}$ & $\begin{array}{r}1.96 \\
.65\end{array}$ & $\begin{array}{r}2.05 \\
.67\end{array}$ & $\begin{array}{r}1.97 \\
.64\end{array}$ & $\begin{array}{r}1.93 \\
.62\end{array}$ & $\begin{array}{r}2.00 \\
.65\end{array}$ & $\begin{array}{r}1.41 \\
.43\end{array}$ & $\begin{array}{l}.03 \\
.02\end{array}$ & $\begin{array}{l}.12 \\
.04\end{array}$ \\
\hline Extraordinary items, net of income taxes.. & * & -.01 & * & .01 & $*$ & & .03 & -.02 & .05 & -.03 \\
\hline Net income $\ldots \ldots \ldots \ldots \ldots \ldots \ldots \ldots \ldots$ & 1.18 & 1.17 & 1.32 & 1.39 & 1.33 & 1.31 & 1.39 & .97 & .05 & .04 \\
\hline Cash dividends declared.. & .89 & .87 & 1.01 & 1.07 & .76 & .75 & .87 & .82 & .37 & .37 \\
\hline Retained income .......... & .29 & .31 & .30 & .31 & .58 & .56 & .51 & .15 & -.32 & -.32 \\
\hline Мемо: Return on equity... & 13.97 & 13.41 & 14.38 & 15.34 & 14.14 & 12.99 & 13.65 & 9.45 & .54 & .42 \\
\hline
\end{tabular}

Note: Data are as of March 23, 2010.

1. Effective October 1, 2008, the Federal Reserve began paying interest on depository institutions' required and excess reserve balances. Beginning with the 2008:Q4 Call Report, balances due from Federal Reserve Banks are now reported under "Interest-earning assets" rather than "Noninterest-earning assets."

2. Includes allocated transfer risk reserve.

3. Measured as the sum of large time deposits in domestic offices, deposits booked in foreign offices, subordinated notes and debentures, federal funds purchased and securities sold under repurchase agreements, Federal Home Loan Bank advances, and other borrowed money.

4. Measured as the sum of construction and land development loans secured by real estate; real estate loans secured by nonfarm nonresidential properties or by multifamily residential properties; and loans to finance commercial real estate, construction, and land development activities not secured by real estate.

5. Other real estate owned is a component of other noninterest-earning assets.

6. When possible, based on the average of quarterly balance sheet data reported on schedule RC-K of the quarterly Call Report.

7. Includes provisions for allocated transfer risk.

* In absolute value, less than 0.005 percent.

n.a. Not available.

MMDA Money market deposit account.

RP Repurchase agreement.

MBS Mortgage-backed securities. 
A.1. Portfolio composition, interest rates, and income and expense, U.S. banks, 2000-09

B. Ten largest banks by assets

\begin{tabular}{|c|c|c|c|c|c|c|c|c|c|c|}
\hline Item & 2000 & 2001 & 2002 & 2003 & 2004 & 2005 & 2006 & 2007 & 2008 & 2009 \\
\hline & \multicolumn{10}{|c|}{ Balance sheet items as a percentage of average net consolidated assets } \\
\hline Interest-earning assets ${ }^{1} \ldots$ & 82.23 & 81.74 & 81.68 & 81.39 & 83.54 & 83.96 & 84.68 & 85.03 & 83.05 & 83.54 \\
\hline Loans and leases (net).. & 55.22 & 53.86 & 53.61 & 52.20 & 51.29 & 51.35 & 52.03 & 53.21 & 50.66 & 46.99 \\
\hline Commercial and industrial & 19.87 & 18.82 & 16.16 & 12.98 & 10.54 & 10.61 & 11.20 & 11.58 & 11.85 & 10.21 \\
\hline U.S. addressees ......... & 13.95 & 13.42 & 11.69 & 9.40 & 7.49 & 7.74 & 8.08 & 8.05 & 8.45 & 7.52 \\
\hline Foreign addressees & 5.92 & 5.41 & 4.47 & 3.59 & 3.06 & 2.87 & 3.12 & 3.53 & 3.40 & 2.69 \\
\hline Consumer ............ & 5.43 & 6.17 & 7.82 & 7.96 & 8.49 & 8.80 & 8.17 & 8.98 & 8.43 & 6.83 \\
\hline Credit card... & 1.34 & 1.69 & 2.90 & 2.81 & 3.19 & 3.60 & 3.05 & 3.87 & 3.54 & 2.16 \\
\hline Installment and other . & 4.09 & 4.48 & 4.92 & 5.15 & 5.30 & 5.21 & 5.13 & 5.11 & 4.89 & 4.67 \\
\hline Real estate ............ & 19.82 & 19.23 & 20.78 & 22.68 & 23.21 & 24.55 & 25.51 & 27.04 & 25.26 & 26.23 \\
\hline In domestic offices $\ldots \ldots \ldots \ldots \ldots$ & 18.48 & 18.05 & 19.70 & 21.74 & 22.21 & 23.52 & 24.50 & 26.00 & 24.29 & 25.39 \\
\hline Construction and land development . & .98 & 1.27 & 1.42 & 1.36 & 1.40 & 1.70 & 2.01 & 2.01 & 1.86 & 1.87 \\
\hline Farmland $\ldots \ldots \ldots \ldots \ldots \ldots \ldots \ldots$ & .11 & .11 & .12 & .10 & .10 & .10 & .10 & .09 & .09 & .09 \\
\hline One- to four-family residential. & 13.37 & 12.41 & 13.51 & 16.03 & 16.71 & 17.73 & 18.30 & 19.86 & 18.40 & 18.95 \\
\hline Home equity .................. & 1.61 & 1.78 & 2.35 & 2.96 & 4.04 & 5.22 & 5.40 & 5.46 & 5.59 & 6.26 \\
\hline Other ............. & 11.76 & 10.63 & 11.17 & 13.07 & 12.67 & 12.52 & 12.90 & 14.40 & 12.81 & 12.69 \\
\hline Multifamily residential. & .60 & .51 & .55 & .47 & .45 & .44 & .44 & .55 & .69 & 1.00 \\
\hline Nonfarm nonresidential & 3.42 & 3.76 & 4.09 & 3.78 & 3.55 & 3.55 & 3.65 & 3.49 & 3.25 & 3.48 \\
\hline In foreign offices ............. & 1.34 & 1.18 & 1.08 & .94 & 1.00 & 1.03 & 1.01 & 1.03 & .97 & .84 \\
\hline \\
\hline acceptances of other banks & 3.78 & 3.23 & 3.20 & 3.54 & 4.10 & 3.15 & 2.97 & 1.71 & 1.67 & 1.27 \\
\hline Foreign governments $\ldots \ldots \ldots \ldots$ & .28 & .20 & .20 & .17 & .16 & .12 & .07 & .05 & .02 & .03 \\
\hline Agricultural production..$\ldots \ldots$. & .23 & .28 & .23 & .19 & .22 & .20 & .20 & .17 & .15 & .16 \\
\hline Other loans.............. & 3.75 & 3.51 & 2.94 & 2.87 & 3.32 & 2.81 & 2.88 & 3.08 & 3.21 & 2.78 \\
\hline Lease-financing receivables.... & 3.07 & 3.43 & 3.44 & 2.87 & 2.08 & 1.78 & 1.60 & 1.22 & 1.06 & .93 \\
\hline LESS: Unearned income on loans & -.04 & -.04 & -.08 & -.06 & -.04 & -.04 & -.02 & -.02 & -.02 & -.02 \\
\hline LEss: Loss reserves ${ }^{2} \ldots \ldots \ldots \ldots$ & -.97 & -.97 & -1.12 & -1.00 & -.79 & -.65 & -.56 & -.60 & -.98 & -1.45 \\
\hline Securities.............. & 18.98 & 17.81 & 20.54 & 21.22 & 22.95 & 23.37 & 23.05 & 21.97 & 20.97 & 22.27 \\
\hline Investment account . . & 13.71 & 12.14 & 14.35 & 15.31 & 15.99 & 15.58 & 15.12 & 12.81 & 12.44 & 16.56 \\
\hline Debt............... & 13.03 & 11.88 & 14.13 & 15.11 & 15.83 & 15.44 & 14.97 & 12.66 & 12.32 & 16.40 \\
\hline U.S. Treasury .............. & 1.96 & .68 & .59 & .82 & .86 & .56 & .43 & .24 & .16 & .51 \\
\hline $\begin{array}{l}\text { U.S. government agency and } \\
\text { corporation obligations } \ldots \ldots \ldots \ldots\end{array}$ & 6.59 & 6.84 & 8.69 & 9.20 & 9.92 & 9.69 & 9.48 & U.S. government agency and & 6.95 & 8.67 \\
\hline Government-backed mortgage pools & 4.88 & $\begin{array}{l}0.04 \\
4.99\end{array}$ & $\begin{array}{l}8.09 \\
6.38\end{array}$ & $\begin{array}{l}9.20 \\
7.59\end{array}$ & $\begin{array}{l}9.92 \\
8.64\end{array}$ & $\begin{array}{l}9.09 \\
8.65\end{array}$ & $\begin{array}{l}9.48 \\
8.64\end{array}$ & $\begin{array}{l}8.02 \\
7.53\end{array}$ & $\begin{array}{l}0.95 \\
6.48\end{array}$ & $\begin{array}{l}8.01 \\
7.25\end{array}$ \\
\hline Collateralized mortgage obligations. & .93 & 1.11 & 1.52 & .91 & .70 & .54 & .53 & .33 & .38 & .66 \\
\hline 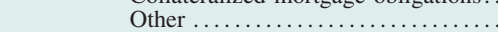 & .78 & .74 & .79 & .70 & .58 & .50 & .32 & .16 & .09 & .75 \\
\hline 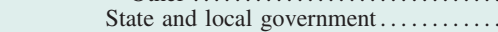 & .51 & .55 & .59 & .59 & .57 & .58 & .64 & .65 & .55 & .68 \\
\hline Private mortgage-backed securities... & .51 & .58 & .92 & 1.10 & .96 & 1.18 & 1.09 & 1.45 & 2.01 & 2.35 \\
\hline 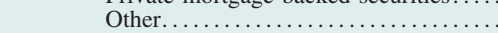 & 3.47 & 3.22 & 3.34 & 3.40 & 3.52 & 3.43 & 3.33 & 2.30 & 2.66 & 4.19 \\
\hline Equity $\ldots \ldots \ldots \ldots \ldots \ldots \ldots \ldots \ldots \ldots \ldots$ & .68 & .26 & .22 & .20 & .16 & .14 & .15 & .16 & .12 & .16 \\
\hline Trading account $\ldots \ldots \ldots \ldots \ldots \ldots \ldots \ldots$ & 5.26 & 5.67 & 6.18 & 5.91 & 6.96 & 7.79 & 7.94 & 9.16 & 8.52 & 5.70 \\
\hline Gross federal funds sold and reverse RPs .. & 5.02 & 6.38 & 5.26 & 5.79 & 6.37 & 6.96 & 7.60 & 7.47 & 8.13 & 6.53 \\
\hline Balances at depositories 1 . . . . . . . . . . & 3.01 & 3.69 & 2.28 & 2.18 & 2.93 & 2.28 & 1.99 & 2.38 & 3.28 & 7.76 \\
\hline Noninterest-earning assets ${ }^{1} \ldots \ldots \ldots \ldots \ldots \ldots$ & 17.77 & 18.26 & 18.32 & 18.61 & 16.46 & 16.04 & 15.32 & 14.97 & 16.95 & 16.46 \\
\hline Revaluation gains held in trading accounts .. & 5.66 & 5.48 & 5.40 & 5.79 & 4.45 & 3.50 & 3.07 & 3.03 & 4.77 & 4.47 \\
\hline 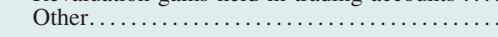 & 12.11 & 12.78 & 12.93 & 12.83 & 12.01 & 12.54 & 12.25 & 11.93 & 12.18 & 11.98 \\
\hline Liabilities....... & 92.36 & 92.14 & 91.52 & 91.94 & 91.64 & 90.81 & 91.10 & 90.82 & 91.34 & 90.78 \\
\hline Core deposits ............. & 33.28 & 36.38 & 40.61 & 41.07 & 42.02 & 40.18 & 38.03 & 35.08 & 34.49 & 39.62 \\
\hline Transaction deposits...$\ldots \ldots \ldots \ldots \ldots$ & 8.01 & 8.40 & 8.34 & 7.74 & 6.65 & 6.05 & 5.41 & 4.69 & 4.73 & 5.80 \\
\hline Demand deposits .................. & 7.28 & 7.50 & 7.40 & 6.72 & 5.43 & 4.90 & 4.32 & 3.80 & 3.91 & 4.84 \\
\hline Other checkable deposits ............. & .74 & .90 & .95 & 1.02 & 1.22 & 1.15 & 1.09 & .89 & .81 & .96 \\
\hline Savings deposits (including MMDAs) .... & 19.24 & 22.21 & 26.82 & 28.99 & 31.54 & 30.11 & 28.11 & 25.55 & 24.59 & 28.41 \\
\hline Small time deposits .................... & 6.03 & 5.77 & 5.44 & 4.34 & 3.83 & 4.02 & 4.52 & 4.84 & 5.18 & 5.41 \\
\hline Managed liabilities $^{3} \ldots \ldots \ldots \ldots \ldots \ldots \ldots$ & 46.84 & 43.41 & 38.89 & 38.60 & 39.33 & 40.83 & 43.75 & 46.83 & 47.69 & 43.51 \\
\hline Large time deposits ........ & 5.55 & 5.46 & 5.13 & 5.53 & 5.21 & 6.28 & 6.85 & 6.13 & 6.72 & 6.11 \\
\hline Deposits booked in foreign offices... & 22.76 & 20.28 & 17.31 & 16.62 & 17.20 & 17.51 & 18.50 & 19.86 & 20.16 & 20.25 \\
\hline Subordinated notes and debentures ...... & 2.10 & 2.16 & 2.11 & 1.92 & 1.78 & 1.89 & 1.99 & 2.17 & 2.09 & 1.87 \\
\hline Gross federal funds purchased and RPs... & 8.89 & 9.04 & 8.83 & 8.62 & 7.79 & 8.39 & 9.51 & 8.42 & 8.18 & 6.79 \\
\hline 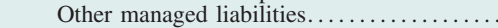 & 7.55 & 6.47 & 5.53 & 5.90 & 7.35 & 6.76 & 6.89 & 10.26 & 10.54 & 8.48 \\
\hline Revaluation losses held in trading accounts... & 5.69 & 5.10 & 4.63 & 4.88 & 3.95 & 3.21 & 2.83 & 2.79 & 3.77 & 3.12 \\
\hline 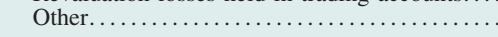 & 6.55 & 7.26 & 7.39 & 7.40 & 6.34 & 6.60 & 6.47 & 6.12 & 5.39 & 4.53 \\
\hline Capital account & 7.64 & 7.86 & 8.48 & 8.06 & 8.36 & 9.19 & 8.90 & 9.18 & 8.66 & 9.22 \\
\hline \multicolumn{11}{|l|}{ Мемо } \\
\hline Commercial real estate loans ${ }^{4}$. . & 5.87 & 6.68 & 6.92 & 6.31 & 5.99 & 6.33 & 6.73 & 6.64 & 6.37 & 6.92 \\
\hline Other real estate owned ${ }^{5} \ldots \ldots$. & .04 & .04 & .03 & .03 & .03 & .02 & .03 & .05 & .09 & .19 \\
\hline Mortgage-backed securities ........... & 6.32 & 6.68 & 8.82 & 9.60 & 10.30 & 10.36 & 10.25 & 9.31 & 8.87 & 10.27 \\
\hline Federal Home Loan Bank advances .... & n.a. & .82 & .82 & .84 & .79 & .63 & .75 & 2.33 & 2.81 & 2.64 \\
\hline Balances at the Federal Reserve ${ }^{1} \ldots \ldots$. & .20 & .27 & .23 & .23 & .25 & .21 & .17 & .15 & 3.92 & 4.29 \\
\hline Interest-earning $\ldots \ldots \ldots \ldots \ldots \ldots$ & n.a. & n.a. & n.a. & n.a. & n.a. & n.a. & n.a. & n.a. & 3.61 & 4.29 \\
\hline Noninterest-earning $\ldots \ldots \ldots \ldots \ldots \ldots$ & .20 & .27 & .23 & .23 & .25 & .21 & .17 & .15 & .32 & n.a. \\
\hline \multicolumn{11}{|l|}{ Interest-earning balances at depositories } \\
\hline other than the Federal Reserve ..... & 3.01 & 3.69 & 2.28 & 2.18 & 2.93 & 2.28 & 1.99 & 2.38 & 2.69 & 3.46 \\
\hline $\begin{array}{l}\text { Average net consolidated assets } \ldots \ldots \ldots \\
\text { (billions of dollars) } \ldots \ldots \ldots \ldots \ldots \ldots\end{array}$ & 2,234 & 2,527 & 2,785 & 3,148 & 3,654 & 4,232 & 4,759 & 5,469 & 6,241 & 6,379 \\
\hline
\end{tabular}


A.1. Portfolio composition, interest rates, and income and expense, U.S. banks, 2000-09_Continued

B. Ten largest banks by assets-Continued

\begin{tabular}{|c|c|c|c|c|c|c|c|c|c|c|}
\hline Item & 2000 & 2001 & 2002 & 2003 & 2004 & 2005 & 2006 & 2007 & 2008 & 2009 \\
\hline & \multicolumn{10}{|c|}{ Effective interest rate (percent) ${ }^{6}$} \\
\hline \multicolumn{11}{|l|}{ Rates earned } \\
\hline Interest-earning assets .... & 7.76 & 6.83 & 5.82 & 4.99 & 4.71 & 5.29 & 6.32 & 6.52 & 5.44 & 4.08 \\
\hline Taxable equivalent & 7.78 & 6.86 & 5.85 & 5.01 & 4.73 & 5.31 & 6.34 & 6.54 & 5.45 & 4.10 \\
\hline Loans and leases, gross ... & 8.46 & 7.50 & 6.52 & 5.76 & 5.52 & 6.15 & 7.36 & 7.33 & 6.14 & 5.00 \\
\hline Net of loss provisions & 7.92 & 6.55 & 5.30 & 5.19 & 5.29 & 5.84 & 7.02 & 6.29 & 3.23 & 1.55 \\
\hline Securities ................. & 6.48 & 6.23 & 5.04 & 4.15 & 4.04 & 4.27 & 4.69 & 4.99 & 4.93 & 4.20 \\
\hline Taxable equivalent & 6.55 & 6.31 & 5.11 & 4.21 & 4.10 & 4.32 & 4.75 & 5.04 & 4.95 & 4.24 \\
\hline Investment account ............... & 6.40 & 6.23 & 5.30 & 4.26 & 4.37 & 4.63 & 5.11 & 5.29 & 5.14 & 4.50 \\
\hline \multicolumn{11}{|l|}{$\begin{array}{l}\text { U.S. Treasury securities and U.S. } \\
\text { government agency obligations }\end{array}$} \\
\hline & n.a. & 5.01 & 3.74 & 2.62 & 2.92 & 3.29 & 4.15 & 4.15 & 3.02 & 2.61 \\
\hline Mortgage-backed securities ....... & n.a. & 6.42 & 5.55 & 4.51 & 4.83 & 4.92 & 5.30 & 5.41 & 5.34 & 4.94 \\
\hline Other .................... & n.a. & 6.34 & 5.30 & 4.28 & 3.76 & 4.26 & 4.81 & 5.08 & 4.77 & 4.09 \\
\hline Trading account $\ldots \ldots \ldots \ldots \ldots \ldots \ldots$ & 6.70 & 6.24 & 4.46 & 3.87 & 3.32 & 3.57 & 3.90 & 4.57 & 4.59 & 3.36 \\
\hline Gross federal funds sold and reverse RPs & 4.93 & 3.86 & 2.20 & 1.60 & 1.43 & 2.46 & 4.07 & 5.06 & 2.59 & .72 \\
\hline Interest-bearing balances at depositories ${ }^{1}$ & 7.43 & 3.73 & 3.40 & 2.49 & 1.80 & 4.06 & 5.59 & 5.36 & 3.46 & .72 \\
\hline \multicolumn{11}{|l|}{ Rates paid } \\
\hline Interest-bearing liabilities .. & 5.03 & 3.78 & 2.33 & 1.67 & 1.62 & 2.52 & 3.74 & 3.87 & 2.47 & 1.04 \\
\hline Interest-bearing deposits. & 4.40 & 3.27 & 1.94 & 1.34 & 1.29 & 2.01 & 2.96 & 3.30 & 2.08 & .79 \\
\hline In foreign offices ..... & 5.67 & 4.02 & 2.59 & 1.74 & 1.81 & 2.77 & 3.88 & 4.28 & 2.52 & .74 \\
\hline In domestic offices............ & 3.51 & 2.84 & 1.67 & 1.18 & 1.08 & 1.70 & 2.55 & 2.80 & 1.85 & .82 \\
\hline Other checkable deposits ............... & 1.61 & 1.67 & .93 & .80 & .97 & 2.27 & 2.46 & 2.36 & 1.13 & .47 \\
\hline Savings deposits (including MMDAs) & 2.43 & 1.92 & 1.02 & .73 & .71 & 1.15 & 1.87 & 1.98 & 1.10 & .36 \\
\hline Large time deposits................. & 5.32 & 4.40 & 3.26 & 2.36 & 2.14 & 3.06 & 4.32 & 4.72 & 3.33 & 1.60 \\
\hline Other time deposits.................. & 5.53 & 5.11 & 3.44 & 2.70 & 2.61 & 3.40 & 4.05 & 4.55 & 3.48 & 2.41 \\
\hline Gross federal funds purchased and RPs & 5.47 & 3.81 & 2.02 & 1.39 & 1.59 & 3.11 & 4.63 & 5.15 & 2.54 & .54 \\
\hline Other interest-bearing liabilities........ & 8.07 & 6.84 & 5.57 & 4.42 & 3.83 & 5.40 & 7.78 & 5.61 & 4.32 & 2.80 \\
\hline & \multicolumn{10}{|c|}{ Income and expense as a percentage of average net consolidated assets } \\
\hline Gross interest income... & 6.39 & 5.55 & 4.77 & 4.05 & 3.94 & 4.47 & 5.46 & 5.61 & 4.52 & 3.53 \\
\hline Taxable equivalent. & 6.41 & 5.57 & 4.79 & 4.07 & 3.96 & 4.48 & 5.48 & 5.63 & 4.53 & 3.54 \\
\hline Loans ................ & 4.74 & 4.13 & 3.57 & 3.04 & 2.86 & 3.19 & 3.91 & 3.98 & 3.15 & 2.45 \\
\hline Securities ................................... & .88 & .72 & .73 & .63 & .69 & .72 & .80 & .69 & .65 & .75 \\
\hline Gross federal funds sold and reverse RPs & .25 & .25 & .12 & .10 & .10 & .18 & .31 & .38 & .20 & .05 \\
\hline Other.......................................... & .51 & .44 & .35 & .28 & .30 & .38 & .45 & .56 & .51 & .27 \\
\hline Gross interest expense. & 3.60 & 2.69 & 1.65 & 1.19 & 1.20 & 1.89 & 2.88 & 3.00 & 1.88 & .82 \\
\hline Deposits............................................ & 2.33 & 1.74 & 1.05 & .74 & .74 & 1.17 & 1.72 & 1.87 & 1.17 & .48 \\
\hline Gross federal funds purchased and RPs & .49 & .35 & .18 & .13 & .13 & .27 & .47 & .46 & .21 & .04 \\
\hline 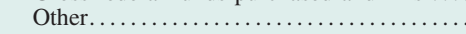 & .78 & .59 & .41 & .33 & .33 & .45 & .69 & .68 & .50 & .29 \\
\hline Net interest income..... & 2.78 & 2.87 & 3.12 & 2.86 & 2.74 & 2.58 & 2.58 & 2.61 & 2.63 & 2.71 \\
\hline Taxable equivalent. & 2.80 & 2.89 & 3.14 & 2.88 & 2.76 & 2.59 & 2.60 & 2.63 & 2.65 & 2.73 \\
\hline Loss provisions $^{7} \ldots \ldots \ldots$ & .38 & .59 & .73 & .35 & .16 & .20 & .22 & .60 & 1.52 & 1.71 \\
\hline Noninterest income............ & 2.54 & 2.26 & 2.31 & 2.32 & 2.21 & 2.37 & 2.35 & 1.95 & 1.66 & 2.17 \\
\hline Service charges on deposits... & .40 & .44 & .48 & .46 & .45 & .42 & .41 & .40 & .40 & .37 \\
\hline Fiduciary activities............ & .27 & .29 & .25 & .26 & .24 & .27 & .23 & .20 & .21 & .21 \\
\hline Trading revenue .......... & .48 & .43 & .32 & .30 & .23 & .31 & .37 & .05 & -.01 & .23 \\
\hline Interest rate exposures .............. & .20 & .20 & .15 & .12 & .07 & .11 & .09 & .08 & -.01 & .13 \\
\hline 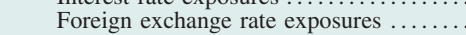 & .18 & .14 & .14 & .14 & .12 & .12 & .14 & .09 & .13 & .09 \\
\hline Other commodity and equity exposures & .11 & .08 & .03 & .04 & .04 & .07 & .13 & .06 & .03 & .04 \\
\hline Credit exposures.......................... & n.a. & n.a. & n.a. & n.a. & n.a. & n.a. & n.a. & -.18 & -.17 & -.03 \\
\hline Other.............................. & 1.39 & 1.10 & 1.26 & 1.30 & 1.28 & 1.38 & $\begin{array}{l}\text { n.a. } \\
1.35\end{array}$ & $\begin{array}{l}-.18 \\
1.31\end{array}$ & $\begin{array}{l}-.17 \\
1.07\end{array}$ & $\begin{array}{l}-.03 \\
1.36\end{array}$ \\
\hline Noninterest expense $\ldots \ldots \ldots \ldots \ldots \ldots$ & 3.31 & 3.13 & 3.16 & 3.02 & 3.11 & 2.99 & 2.89 & 2.80 & 2.71 & 2.71 \\
\hline Salaries, wages, and employee benefits. & 1.46 & 1.38 & 1.41 & 1.39 & 1.34 & 1.38 & 1.39 & 1.32 & 1.20 & 1.28 \\
\hline Occupancy $\ldots \ldots \ldots \ldots \ldots \ldots \ldots \ldots \ldots \ldots \ldots \ldots$ & .47 & .45 & .46 & .45 & .43 & .43 & .40 & .37 & .35 & .36 \\
\hline Other. $\ldots \ldots \ldots \ldots \ldots \ldots \ldots \ldots \ldots$ & 1.39 & 1.30 & 1.28 & 1.18 & 1.33 & 1.19 & 1.09 & 1.12 & 1.17 & 1.08 \\
\hline Net noninterest expense $\ldots \ldots \ldots \ldots \ldots \ldots \ldots$ & .77 & .87 & .85 & .70 & .91 & .62 & .54 & .85 & 1.05 & .55 \\
\hline Gains on investment account securities ..... & -.03 & .08 & .13 & .11 & .07 & $*$ & -.01 & .02 & -.05 & -.03 \\
\hline 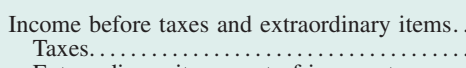 & $\begin{array}{r}1.60 \\
.60\end{array}$ & $\begin{array}{r}1.48 \\
.49\end{array}$ & $\begin{array}{r}1.67 \\
.56\end{array}$ & $\begin{array}{r}1.92 \\
.63\end{array}$ & $\begin{array}{r}1.74 \\
.56\end{array}$ & $\begin{array}{r}1.75 \\
.57\end{array}$ & $\begin{array}{r}1.82 \\
.59\end{array}$ & $\begin{array}{r}1.18 \\
.33\end{array}$ & $\begin{array}{c}* \\
-.07\end{array}$ & $\begin{array}{l}.42 \\
.06\end{array}$ \\
\hline Extraordinary items, net of income taxes.. & * & -.01 & $*$ & & $*$ & & .02 & & .09 & $*$ \\
\hline Net income $\ldots \ldots \ldots \ldots \ldots \ldots \ldots \ldots \ldots \ldots \ldots \ldots \ldots \ldots \ldots \ldots$ & 1.00 & .99 & 1.11 & 1.29 & 1.18 & 1.18 & 1.25 & .85 & .16 & .35 \\
\hline Cash dividends declared. & .86 & .66 & 1.05 & .99 & .65 & .59 & .64 & .60 & .28 & .47 \\
\hline Retained income .......... & .13 & .32 & .06 & .30 & .53 & .59 & .62 & .25 & -.11 & -.11 \\
\hline Memo: Return on equity $\ldots \ldots \ldots \ldots \ldots$ & 13.04 & 12.55 & 13.14 & 16.06 & 14.07 & 12.86 & 14.08 & 9.23 & 1.89 & 3.81 \\
\hline
\end{tabular}

Note: Data are as of March 23, 2010.

1. Effective October 1, 2008, the Federal Reserve began paying interest on depository institutions' required and excess reserve balances. Beginning with the 2008:Q4 Call Report, balances due from Federal Reserve Banks are now reported under "Interest-earning assets" rather than "Noninterest-earning assets."

2. Includes allocated transfer risk reserve.

3. Measured as the sum of large time deposits in domestic offices, deposits booked in foreign offices, subordinated notes and debentures, federal funds purchased and securities sold under repurchase agreements, Federal Home Loan Bank advances, and other borrowed money.

4. Measured as the sum of construction and land development loans secured by real estate; real estate loans secured by nonfarm nonresidential properties or by multifamily residential properties; and loans to finance commercial real estate, construction, and land development activities not secured by real estate.

5. Other real estate owned is a component of other noninterest-earning assets.

6. When possible, based on the average of quarterly balance sheet data reported on schedule RC-K of the quarterly Call Report.

7. Includes provisions for allocated transfer risk.

* In absolute value, less than 0.005 percent.

n.a. Not available.

MMDA Money market deposit account.

RP Repurchase agreement.

MBS Mortgage-backed securities. 
A.1. Portfolio composition, interest rates, and income and expense, U.S. banks, 2000-09

C. Banks ranked 11 through 100 by assets

\begin{tabular}{|c|c|c|c|c|c|c|c|c|c|c|}
\hline Item & 2000 & 2001 & 2002 & 2003 & 2004 & 2005 & 2006 & 2007 & 2008 & 2009 \\
\hline & \multicolumn{10}{|c|}{ Balance sheet items as a percentage of average net consolidated assets } \\
\hline Interest-earning assets ${ }^{1} \ldots$ & 88.67 & 88.09 & 88.34 & 88.10 & 88.18 & 87.87 & 87.05 & 87.01 & 85.34 & 85.84 \\
\hline Loans and leases (net). & 64.88 & 62.14 & 60.00 & 59.48 & 60.63 & 63.37 & 62.77 & 60.99 & 60.04 & 58.58 \\
\hline Commercial and industrial & 18.19 & 15.84 & 13.27 & 11.96 & 11.90 & 12.17 & 12.13 & 12.74 & 12.79 & 11.88 \\
\hline U.S. addressees ......... & 17.64 & 15.36 & 12.94 & 11.66 & 11.64 & 11.91 & 11.81 & 12.41 & 12.46 & 11.53 \\
\hline Foreign addressees . & .55 & .48 & .33 & .30 & .26 & .27 & .32 & .33 & .34 & .35 \\
\hline Consumer ............ & 13.79 & 13.20 & 12.79 & 12.57 & 12.74 & 12.84 & 11.94 & 9.99 & 10.61 & 12.96 \\
\hline Credit card............. & 6.97 & 7.05 & 6.56 & 6.35 & 6.90 & 7.45 & 7.12 & 5.29 & 5.67 & 8.20 \\
\hline Installment and other . & 6.82 & 6.15 & 6.22 & 6.21 & 5.83 & 5.39 & 4.82 & 4.70 & 4.94 & 4.76 \\
\hline Real estate ............ & 26.21 & 27.29 & 28.94 & 30.67 & 32.16 & 34.89 & 35.23 & 33.53 & 32.50 & 31.21 \\
\hline In domestic offices $\ldots \ldots \ldots \ldots \ldots$ & 26.12 & 27.21 & 28.88 & 30.54 & 31.96 & 34.73 & 35.03 & 33.35 & 32.19 & 30.93 \\
\hline Construction and land development . & 3.00 & 3.31 & 3.36 & 3.22 & 3.51 & 4.21 & 5.27 & 5.95 & 5.65 & 4.45 \\
\hline Farmland $\ldots \ldots \ldots \ldots \ldots \ldots \ldots \ldots$ & .22 & .23 & .22 & .20 & .19 & .19 & .17 & .21 & .26 & .28 \\
\hline One- to four-family residential. & 14.51 & 15.51 & 17.05 & 18.79 & 19.52 & 21.05 & 20.27 & 17.80 & 16.57 & 16.19 \\
\hline Home equity ................ & 2.49 & 2.90 & 3.92 & 4.74 & 5.90 & 6.04 & 5.01 & 4.01 & 3.90 & 4.17 \\
\hline Other ............. & 12.02 & 12.60 & 13.13 & 14.05 & 13.62 & 15.01 & 15.26 & 13.79 & 12.67 & 12.02 \\
\hline Multifamily residential. & 1.11 & 1.16 & 1.20 & 1.32 & 1.34 & 1.45 & 1.45 & 1.27 & 1.25 & 1.31 \\
\hline Nonfarm nonresidential & 7.28 & 6.99 & 7.05 & 7.00 & 7.41 & 7.83 & 7.86 & 8.13 & 8.47 & 8.71 \\
\hline In foreign offices ............ & .09 & .09 & .06 & .13 & .20 & .16 & .21 & .18 & .31 & .28 \\
\hline \multicolumn{11}{|l|}{ To depository institutions and } \\
\hline & 1.05 & 1.40 & 1.44 & 1.21 & .54 & .56 & .45 & 1.05 & .94 & 1.07 \\
\hline Foreign governments $\ldots \ldots \ldots \ldots$ & .03 & .03 & .02 & .02 & .01 & .02 & .01 & .01 & .03 & .01 \\
\hline Agricultural production ......... & .37 & .32 & .27 & .23 & .19 & .19 & .18 & .21 & .23 & .22 \\
\hline Other loans.............. & 2.57 & 2.03 & 1.80 & 1.59 & 1.87 & 1.62 & 1.88 & 2.43 & 2.56 & 1.98 \\
\hline Lease-financing receivables.... & 3.82 & 3.18 & 2.65 & 2.35 & 2.30 & 2.07 & 1.83 & 1.80 & 1.50 & 1.31 \\
\hline LESS: Unearned income on loans & -.03 & -.02 & -.02 & -.02 & -.02 & -.01 & -.01 & -.01 & -.01 & -.01 \\
\hline LESS: Loss reserves ${ }^{2} \ldots \ldots \ldots \ldots$ & -1.12 & -1.13 & -1.17 & -1.10 & -1.06 & -.97 & -.87 & -.75 & -1.12 & -2.05 \\
\hline Securities............. & 17.32 & 19.00 & 20.30 & 21.16 & 21.28 & 19.96 & 19.22 & 19.89 & 16.88 & 18.31 \\
\hline Investment account & 16.10 & 17.71 & 19.17 & 20.09 & 20.12 & 18.80 & 17.72 & 17.99 & 14.99 & 15.80 \\
\hline Debt............... & 15.50 & 17.32 & 18.82 & 19.88 & 19.96 & 18.69 & 17.60 & 17.88 & 14.84 & 15.41 \\
\hline U.S. Treasury .............. & 1.12 & .67 & .74 & .95 & .89 & .60 & .44 & .38 & .31 & .58 \\
\hline \multicolumn{10}{|l|}{ U.S. government agency and } & 8.66 \\
\hline Government-backed mortgage pools & 4.31 & $\begin{array}{r}10.09 \\
5.19\end{array}$ & $\begin{array}{r}11.43 \\
6.00\end{array}$ & $\begin{array}{r}12.99 \\
6.08\end{array}$ & $\begin{array}{r}12.80 \\
5.74\end{array}$ & $\begin{array}{r}11.02 \\
4.83\end{array}$ & $\begin{array}{r}10.07 \\
4.04\end{array}$ & $\begin{array}{l}9.06 \\
3.73\end{array}$ & $\begin{array}{l}1.72 \\
3.76\end{array}$ & $\begin{array}{l}8.66 \\
4.56\end{array}$ \\
\hline Collateralized mortgage obligations. & 2.55 & 2.42 & 2.79 & 3.72 & 3.42 & 3.39 & 2.94 & 2.68 & 2.43 & 2.59 \\
\hline Other ............................ & 2.84 & 2.48 & 2.65 & 3.19 & 3.64 & 3.40 & 3.10 & 2.65 & 1.54 & 1.51 \\
\hline State and local government........... & .96 & .99 & .97 & .95 & .96 & .98 & 1.01 & 1.16 & 1.03 & .89 \\
\hline Private mortgage-backed securities... & 1.66 & 2.01 & 2.13 & 2.14 & 2.65 & 3.58 & 4.29 & 4.60 & 3.23 & 1.78 \\
\hline 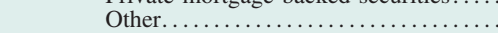 & 2.06 & 3.56 & 3.53 & 2.85 & 2.66 & 1.90 & 1.78 & 2.67 & 2.54 & 3.50 \\
\hline Equity $\ldots \ldots \ldots \ldots \ldots \ldots \ldots \ldots \ldots \ldots$ & .60 & .39 & .34 & .21 & .16 & .11 & .12 & .12 & .14 & .39 \\
\hline Trading account $\ldots \ldots \ldots \ldots \ldots \ldots \ldots \ldots \ldots$ & 1.22 & 1.29 & 1.13 & 1.07 & 1.16 & 1.16 & 1.50 & 1.90 & 1.89 & 2.52 \\
\hline Gross federal funds sold and reverse RPs. & 3.76 & 4.06 & 4.71 & 4.20 & 2.98 & 2.30 & 2.84 & 3.41 & 4.27 & 2.46 \\
\hline Balances at depositories 1 . ............. & 2.71 & 2.88 & 3.33 & 3.26 & 3.29 & 2.24 & 2.22 & 2.72 & 4.16 & 6.48 \\
\hline Noninterest-earning assets ${ }^{1} \ldots \ldots \ldots \ldots \ldots \ldots$ & 11.33 & 11.91 & 11.66 & 11.90 & 11.82 & 12.13 & 12.95 & 12.99 & 14.66 & 14.16 \\
\hline Revaluation gains held in trading accounts ... & .40 & .55 & .47 & .60 & .42 & .33 & .30 & .48 & .91 & 1.36 \\
\hline 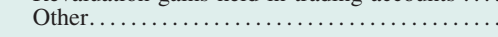 & 10.92 & 11.37 & 11.19 & 11.30 & 11.40 & 11.80 & 12.65 & 12.51 & 13.75 & 12.80 \\
\hline Liabilities....... & 91.57 & 91.15 & 90.79 & 90.65 & 89.87 & 88.86 & 88.08 & 88.40 & 88.17 & 87.01 \\
\hline Core deposits ............. & 46.28 & 46.28 & 47.07 & 47.93 & 46.55 & 48.18 & 46.84 & 47.44 & 46.35 & 50.91 \\
\hline Transaction deposits...$\ldots \ldots \ldots \ldots \ldots$ & 9.93 & 8.37 & 7.49 & 7.29 & 7.06 & 6.64 & 5.74 & 5.15 & 5.13 & 5.44 \\
\hline Demand deposits .................. & 8.61 & 7.17 & 6.32 & 5.96 & 5.65 & 5.35 & 4.54 & 3.90 & 3.89 & 3.98 \\
\hline Other checkable deposits ............. & 1.32 & 1.20 & 1.17 & 1.33 & 1.41 & 1.29 & 1.20 & 1.25 & 1.24 & 1.46 \\
\hline Savings deposits (including MMDAs) .... & 24.02 & 26.62 & 30.07 & 32.34 & 31.75 & 33.33 & 32.66 & 32.99 & 31.50 & 34.24 \\
\hline 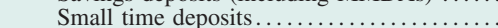 & 12.33 & 11.28 & 9.51 & 8.30 & 7.74 & 8.20 & 8.44 & 9.30 & 9.71 & 11.23 \\
\hline Managed liabilities $^{3} \ldots \ldots \ldots \ldots \ldots \ldots \ldots$ & 41.98 & 40.81 & 39.48 & 38.12 & 39.29 & 37.04 & 37.60 & 37.02 & 37.82 & 32.01 \\
\hline Large time deposits ........ & 9.54 & 9.72 & 8.99 & 8.20 & 8.76 & 10.10 & 11.44 & 10.20 & 9.76 & 7.28 \\
\hline Deposits booked in foreign offices... & 7.56 & 7.05 & 6.28 & 6.54 & 7.21 & 6.02 & 6.43 & 8.52 & 7.80 & 5.78 \\
\hline Subordinated notes and debentures ...... & 1.54 & 1.53 & 1.44 & 1.38 & 1.39 & 1.31 & 1.32 & 1.40 & 1.31 & 1.32 \\
\hline Gross federal funds purchased and RPs... & 9.28 & 9.71 & 9.66 & 9.69 & 8.95 & 7.17 & 6.74 & 6.79 & 6.72 & 6.63 \\
\hline 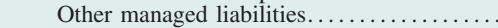 & 14.07 & 12.79 & 13.11 & 12.30 & 12.97 & 12.44 & 11.66 & 10.10 & 12.23 & 11.00 \\
\hline Revaluation losses held in trading accounts... & .41 & .52 & .44 & .56 & .40 & .34 & .29 & .47 & .85 & 1.10 \\
\hline 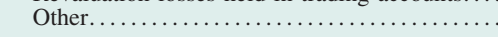 & 2.91 & 3.54 & 3.80 & 4.05 & 3.64 & 3.30 & 3.35 & 3.48 & 3.16 & 2.98 \\
\hline Capital account & 8.43 & 8.85 & 9.21 & 9.35 & 10.13 & 11.14 & 11.92 & 11.60 & 11.83 & 12.99 \\
\hline \multicolumn{11}{|l|}{ Мемо } \\
\hline Commercial real estate loans ${ }^{4}$. . & 12.06 & 12.06 & 12.24 & 12.10 & 12.85 & 13.93 & 15.05 & 15.95 & 16.01 & 15.04 \\
\hline Other real estate owned ${ }^{5} \ldots \ldots$. & .03 & .04 & .05 & .06 & .05 & .04 & .05 & .06 & .10 & .21 \\
\hline Mortgage-backed securities ........... & 8.52 & 9.63 & 10.93 & 11.93 & 11.81 & 11.81 & 11.27 & 11.01 & 9.42 & 8.93 \\
\hline Federal Home Loan Bank advances ..... & n.a. & 4.07 & 4.85 & 4.75 & 4.65 & 5.19 & 5.54 & 5.35 & 6.45 & 4.82 \\
\hline Balances at the Federal Reserve ${ }^{1} \ldots \ldots$. & .43 & .36 & .37 & .37 & .28 & .21 & .18 & .19 & 3.89 & 4.73 \\
\hline Interest-earning $\ldots \ldots \ldots \ldots \ldots \ldots \ldots$ & n.a. & n.a. & n.a. & n.a. & n.a. & n.a. & n.a. & n.a. & 3.18 & 4.73 \\
\hline & .43 & .36 & .37 & .37 & .28 & .21 & .18 & .19 & .72 & n.a. \\
\hline \multicolumn{11}{|l|}{ Interest-earning balances at depositories } \\
\hline other than the Federal Reserve ..... & 2.71 & 2.88 & 3.33 & 3.26 & 3.29 & 2.24 & 2.22 & 2.72 & 3.43 & 1.75 \\
\hline $\begin{array}{l}\text { Average net consolidated assets } \\
\text { (billions of dollars) } \ldots \ldots \ldots \ldots \ldots\end{array}$ & 2,031 & 2,130 & 2,124 & 2,287 & 2,376 & 2,403 & 2,579 & 2,798 & 3,177 & 3,281 \\
\hline
\end{tabular}


A.1. Portfolio composition, interest rates, and income and expense, U.S. banks, 2000-09_Continued

C. Banks ranked 11 through 100 by assets-Continued

\begin{tabular}{|c|c|c|c|c|c|c|c|c|c|c|}
\hline Item & 2000 & 2001 & 2002 & 2003 & 2004 & 2005 & 2006 & 2007 & 2008 & 2009 \\
\hline & \multicolumn{10}{|c|}{ Effective interest rate (percent) ${ }^{6}$} \\
\hline \multicolumn{11}{|l|}{ Rates earned } \\
\hline Interest-earning assets $\ldots$. & 8.44 & 7.54 & 6.03 & 5.30 & 5.21 & 5.98 & 6.93 & 6.87 & 5.83 & 5.14 \\
\hline Taxable equivalent & 8.48 & 7.58 & 6.07 & 5.33 & 5.24 & 6.02 & 6.97 & 6.91 & 5.85 & 5.16 \\
\hline Loans and leases, gross .... & 9.14 & 8.26 & 6.80 & 6.11 & 5.98 & 6.61 & 7.58 & 7.45 & 6.43 & 6.03 \\
\hline Net of loss provisions & 8.25 & 6.96 & 5.59 & 5.11 & 5.19 & 5.89 & 7.04 & 6.64 & 3.75 & 1.64 \\
\hline Securities ................. & 6.64 & 5.96 & 4.79 & 3.80 & 3.63 & 4.18 & 4.99 & 5.25 & 4.78 & 4.01 \\
\hline Taxable equivalent & 6.77 & 6.08 & 4.91 & 3.90 & 3.73 & 4.29 & 5.10 & 5.37 & 4.86 & 4.06 \\
\hline 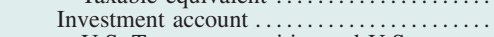 & 6.66 & 6.04 & 4.86 & 3.87 & 3.64 & 4.11 & 4.84 & 5.18 & 4.74 & 4.03 \\
\hline \multicolumn{11}{|l|}{$\begin{array}{l}\text { U.S. Treasury securities and U.S. } \\
\text { government agency obligations }\end{array}$} \\
\hline & n.a. & 5.83 & 4.28 & 3.17 & 2.94 & 3.47 & 4.28 & 4.85 & 3.92 & 1.95 \\
\hline Mortgage-backed securities ..... & n.a. & 6.60 & 5.34 & 4.20 & 4.02 & 4.34 & 5.02 & 5.23 & 5.02 & 4.76 \\
\hline Other .................... & $\begin{array}{l}\text { n.a. } \\
\text { n.a. }\end{array}$ & 5.13 & 4.22 & 3.61 & 3.29 & 4.06 & 4.87 & 5.28 & 4.42 & 3.56 \\
\hline Trading account $\ldots \ldots \ldots \ldots \ldots \ldots \ldots$ & 6.25 & 4.83 & 3.59 & 2.56 & 3.39 & 5.30 & 6.74 & 5.94 & 5.06 & 3.87 \\
\hline Gross federal funds sold and reverse RPs & 6.06 & 3.86 & 1.68 & 1.14 & 1.25 & 3.24 & 4.95 & 5.16 & 2.29 & .38 \\
\hline Interest-bearing balances at depositories ${ }^{1}$. & $\begin{array}{l}0.00 \\
5.49\end{array}$ & $\begin{array}{l}.00 \\
4.38\end{array}$ & $\begin{array}{l}1.00 \\
2.46\end{array}$ & 1.93 & 2.27 & 3.20 & 4.24 & 4.84 & 2.97 & .54 \\
\hline \multicolumn{11}{|l|}{ Rates paid } \\
\hline Interest-bearing liabilities .. & 4.97 & 3.94 & 2.22 & 1.61 & 1.56 & 2.44 & 3.48 & 3.72 & 2.38 & 1.34 \\
\hline Interest-bearing deposits. & 4.42 & 3.60 & 1.96 & 1.35 & 1.29 & 2.03 & 3.07 & 3.33 & 2.14 & 1.19 \\
\hline In foreign offices ..... & 5.38 & 3.67 & 1.70 & 1.23 & 1.42 & 2.76 & 4.10 & 4.01 & 2.21 & .38 \\
\hline In domestic offices............ & 4.26 & 3.60 & 1.99 & 1.36 & 1.27 & 1.95 & 2.95 & 3.22 & 2.12 & 1.27 \\
\hline Other checkable deposits .............. & 2.57 & 2.32 & .94 & .64 & .72 & 1.29 & 2.12 & 2.60 & 1.32 & .45 \\
\hline Savings deposits (including MMDAs) & 2.94 & 2.30 & 1.08 & .66 & .65 & 1.30 & 2.14 & 2.44 & 1.32 & .55 \\
\hline Large time deposits................. & 5.88 & 5.11 & 3.37 & 2.70 & 2.49 & 3.31 & 4.45 & 4.46 & 3.14 & 2.38 \\
\hline Other time deposits.................. & 5.73 & 5.42 & 3.68 & 2.95 & 2.58 & 3.03 & 4.09 & 4.74 & 3.85 & 2.90 \\
\hline \multirow{3}{*}{$\begin{array}{l}\text { Gross federal funds purchased and RPs } \\
\text { Other interest-bearing liabilities.......... }\end{array}$} & 6.02 & 3.86 & 1.73 & 1.20 & 1.37 & 3.04 & 4.46 & 4.71 & 2.07 & .64 \\
\hline & 6.25 & 5.29 & 3.65 & 3.04 & 2.77 & 3.81 & 4.90 & 5.25 & 3.66 & 2.42 \\
\hline & \multicolumn{10}{|c|}{ Income and expense as a percentage of average net consolidated assets } \\
\hline Gross interest income... & 7.54 & 6.70 & 5.31 & 4.67 & 4.63 & 5.28 & 6.08 & 5.99 & 4.99 & 4.49 \\
\hline Taxable equivalent. . & 7.57 & 6.73 & 5.34 & 4.70 & 4.65 & 5.31 & 6.11 & 6.02 & 5.01 & 4.50 \\
\hline Loans ................ & 6.05 & 5.28 & 4.15 & 3.72 & 3.71 & 4.27 & 4.85 & 4.60 & 3.94 & 3.67 \\
\hline Securities............................ & 1.09 & 1.06 & .90 & .75 & .73 & .77 & .87 & .93 & .71 & .65 \\
\hline Gross federal funds sold and reverse RPs & .22 & .15 & .08 & .04 & .03 & .06 & .13 & .17 & .09 & .01 \\
\hline Other......................................... & .18 & .21 & .18 & .15 & .15 & .18 & .23 & .29 & .24 & .16 \\
\hline Gross interest expense. & 3.96 & 3.14 & 1.77 & 1.30 & 1.26 & 1.94 & 2.78 & 2.96 & 1.88 & 1.06 \\
\hline Deposits......................................... & 2.41 & 2.01 & 1.09 & .77 & .74 & 1.18 & 1.84 & 2.04 & 1.26 & .72 \\
\hline Gross federal funds purchased and RPs & .56 & .38 & .17 & .12 & .13 & .23 & .30 & .32 & .14 & .04 \\
\hline 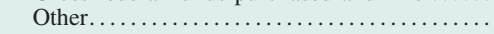 & .99 & .75 & .51 & .41 & .40 & .53 & .63 & .59 & .48 & .30 \\
\hline Net interest income..... & 3.58 & 3.56 & 3.54 & 3.37 & 3.36 & 3.34 & 3.30 & 3.03 & 3.11 & 3.43 \\
\hline Taxable equivalent. & 3.61 & 3.59 & 3.57 & 3.40 & 3.39 & 3.37 & 3.33 & 3.06 & 3.13 & 3.45 \\
\hline Loss provisions $^{7} \ldots \ldots \ldots$ & .68 & .91 & .80 & .67 & .55 & .52 & .41 & .55 & 1.69 & 2.71 \\
\hline Noninterest income........... & 3.18 & 3.35 & 3.30 & 3.29 & 3.09 & 2.81 & 2.91 & 2.73 & 2.38 & 2.35 \\
\hline Service charges on deposits.. & .42 & .42 & .42 & .42 & .40 & .37 & .35 & .33 & .32 & .30 \\
\hline Fiduciary activities.......... & .52 & .42 & .42 & .37 & .42 & .35 & .41 & .54 & .41 & .24 \\
\hline Trading revenue .......... & .07 & .08 & .08 & .09 & .07 & .06 & .07 & .09 & -.01 & .26 \\
\hline Interest rate exposures ............... & .02 & .04 & .04 & .04 & -.01 & -.01 & .02 & $*$ & -.02 & .18 \\
\hline 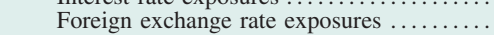 & .04 & .03 & .04 & .04 & .05 & .04 & .05 & .08 & .08 & -.03 \\
\hline Other commodity and equity exposures. & $*$ & $*$ & $*$ & .01 & .03 & .02 & $*$ & $*$ & $*$ & $*$ \\
\hline Credit exposures....................... & & & & n.a. & n.a. & n.a. & n.a. & .01 & -.06 & .11 \\
\hline Other...................... & 2.18 & 2.43 & 2.37 & 2.41 & 2.20 & 2.03 & 2.09 & 1.77 & 1.65 & 1.56 \\
\hline Noninterest expense $\ldots \ldots \ldots \ldots \ldots \ldots \ldots$ & 4.00 & 3.95 & 3.73 & 3.64 & 3.55 & 3.36 & 3.34 & 3.45 & 3.56 & 3.29 \\
\hline Salaries, wages, and employee benefits..... & 1.44 & 1.47 & 1.49 & 1.47 & 1.45 & 1.37 & 1.34 & 1.32 & 1.22 & 1.14 \\
\hline Occupancy $\ldots \ldots \ldots \ldots \ldots \ldots \ldots \ldots$ & .43 & .42 & .40 & .41 & .39 & .37 & .33 & .34 & .32 & .31 \\
\hline Other. $\ldots \ldots \ldots \ldots \ldots+\ldots \ldots+\ldots$ & 2.14 & 2.07 & 1.84 & 1.76 & 1.70 & 1.62 & 1.68 & 1.79 & 2.02 & 1.85 \\
\hline Net noninterest expense $\ldots \ldots \ldots \ldots \ldots \ldots \ldots \ldots$ & .82 & .60 & .43 & .35 & .45 & .55 & .43 & .72 & 1.18 & .94 \\
\hline Gains on investment account securities ....... & -.05 & .09 & .10 & .06 & .03 & $*$ & -.03 & -.05 & -.30 & .01 \\
\hline $\begin{array}{l}\text { Income before taxes and extraordinary items.... } \\
\text { Taxes. } \ldots \ldots \ldots \ldots \ldots \ldots \ldots \ldots \ldots \ldots \ldots \ldots \ldots\end{array}$ & $\begin{array}{r}2.02 \\
.70\end{array}$ & $\begin{array}{r}2.14 \\
.74\end{array}$ & $\begin{array}{r}2.41 \\
.82\end{array}$ & $\begin{array}{r}2.42 \\
.82\end{array}$ & $\begin{array}{r}2.39 \\
.82\end{array}$ & $\begin{array}{r}2.27 \\
.77\end{array}$ & $\begin{array}{r}2.43 \\
.83\end{array}$ & $\begin{array}{r}1.71 \\
.59\end{array}$ & $\begin{array}{r}-.06 \\
.13\end{array}$ & -.21 \\
\hline Extraordinary items, net of income taxes...... & $*$ & $* *^{*}$ & $* 82$ & .82 & $\stackrel{82}{*}$ & .01 & $\begin{array}{l}.83 \\
.07\end{array}$ & $\begin{array}{r}.59 \\
-.05\end{array}$ & $\begin{array}{r}.13 \\
-.01\end{array}$ & -.12 \\
\hline Net income $\ldots \ldots \ldots \ldots \ldots \ldots \ldots \ldots \ldots \ldots \ldots \ldots \ldots \ldots \ldots$ & 1.32 & 1.39 & 1.59 & 1.59 & 1.57 & 1.50 & 1.67 & 1.06 & -.20 & -.33 \\
\hline Cash dividends declared.. & .94 & .96 & .99 & 1.05 & .95 & 1.00 & 1.37 & 1.26 & .44 & .18 \\
\hline Retained income .......... & .38 & .43 & .60 & .54 & .62 & .50 & .30 & -.20 & -.63 & -.52 \\
\hline Meмо: Return on equity $\ldots \ldots \ldots \ldots \ldots$ & 15.72 & 15.74 & 17.24 & 17.03 & 15.54 & 13.48 & 14.05 & 9.16 & -1.67 & -2.55 \\
\hline
\end{tabular}

Note: Data are as of March 23, 2010.

1. Effective October 1, 2008, the Federal Reserve began paying interest on depository institutions' required and excess reserve balances. Beginning with the 2008:Q4 Call Report, balances due from Federal Reserve Banks are now reported under "Interest-earning assets" rather than "Noninterest-earning assets."

2. Includes allocated transfer risk reserve.

3. Measured as the sum of large time deposits in domestic offices, deposits booked in foreign offices, subordinated notes and debentures, federal funds purchased and securities sold under repurchase agreements, Federal Home Loan Bank advances, and other borrowed money.

4. Measured as the sum of construction and land development loans secured by real estate; real estate loans secured by nonfarm nonresidential properties or by multifamily residential properties; and loans to finance commercial real estate, construction, and land development activities not secured by real estate.

5. Other real estate owned is a component of other noninterest-earning assets.

6. When possible, based on the average of quarterly balance sheet data reported on schedule RC-K of the quarterly Call Report.

7. Includes provisions for allocated transfer risk.

* In absolute value, less than 0.005 percent.

n.a. Not available.

MMDA Money market deposit account.

RP Repurchase agreement.

MBS Mortgage-backed securities. 
A.1. Portfolio composition, interest rates, and income and expense, U.S. banks, 2000-09

D. Banks ranked 101 through 1,000 by assets

\begin{tabular}{|c|c|c|c|c|c|c|c|c|c|c|}
\hline Item & 2000 & 2001 & 2002 & 2003 & 2004 & 2005 & 2006 & 2007 & 2008 & 2009 \\
\hline & \multicolumn{10}{|c|}{ Balance sheet items as a percentage of average net consolidated assets } \\
\hline Interest-earning assets ${ }^{1} \ldots$ & 91.50 & 91.16 & 91.36 & 91.34 & 91.56 & 91.32 & 91.07 & 91.28 & 91.28 & 91.30 \\
\hline Loans and leases (net).......... & 62.15 & 62.46 & 61.46 & 61.32 & 63.33 & 65.15 & 67.04 & 68.85 & 70.52 & 67.68 \\
\hline Commercial and industrial & 12.95 & 13.03 & 12.38 & 11.50 & 11.52 & 11.78 & 11.68 & 12.07 & 12.58 & 11.38 \\
\hline U.S. addressees ......... & 12.60 & 12.65 & 12.06 & 11.20 & 11.21 & 11.48 & 11.45 & 11.80 & 12.31 & 11.17 \\
\hline Foreign addressees . & .36 & .38 & .31 & .31 & .31 & .30 & .23 & .27 & .27 & .21 \\
\hline Consumer ........... & 10.19 & 9.76 & 8.13 & 6.80 & 6.33 & 5.42 & 5.50 & 5.35 & 5.15 & 4.73 \\
\hline Credit card... & 3.27 & 3.65 & 2.63 & 1.82 & 1.91 & 1.24 & 1.63 & 1.88 & 1.76 & 1.23 \\
\hline Installment and other . & 6.92 & 6.11 & 5.50 & 4.98 & 4.42 & 4.18 & 3.87 & 3.46 & 3.39 & 3.50 \\
\hline Real estate ............ & 36.93 & 37.64 & 38.92 & 40.95 & 43.38 & 45.86 & 47.88 & 49.50 & 50.78 & 50.00 \\
\hline In domestic offices $\ldots \ldots \ldots \ldots \ldots$ & 36.91 & 37.62 & 38.89 & 40.90 & 43.32 & 45.78 & 47.78 & 49.41 & 50.77 & 49.99 \\
\hline Construction and land development . & 4.15 & 4.90 & 5.40 & 5.89 & 7.01 & 8.86 & 11.01 & 12.85 & 13.04 & 10.59 \\
\hline Farmland $\ldots \ldots \ldots \ldots \ldots \ldots \ldots \ldots$ & .65 & .66 & .73 & .80 & .91 & .99 & 1.07 & 1.16 & 1.22 & 1.30 \\
\hline One- to four-family residential. & 17.17 & 16.18 & 15.39 & 15.71 & 15.33 & 15.17 & 14.76 & 14.08 & 14.16 & 14.64 \\
\hline Home equity .................. & 2.10 & 2.21 & 2.51 & 2.92 & 3.46 & 3.60 & 3.25 & 3.01 & 3.19 & 3.39 \\
\hline Other ............. & 15.06 & 13.97 & 12.88 & 12.79 & 11.87 & 11.57 & 11.51 & 11.07 & 10.97 & 11.24 \\
\hline Multifamily residential. & 1.58 & 1.69 & 1.83 & 2.00 & 2.24 & 2.37 & 2.32 & 2.33 & 2.41 & 2.48 \\
\hline Nonfarm nonresidential & 13.36 & 14.18 & 15.55 & 16.51 & 17.82 & 18.39 & 18.63 & 18.99 & 19.95 & 21.00 \\
\hline In foreign offices ............ & .02 & .02 & .03 & .05 & .06 & .08 & $\begin{array}{r}10.05 \\
.10\end{array}$ & $\begin{array}{r}10.09 \\
.09\end{array}$ & $*$ & $* 2.00$ \\
\hline \multicolumn{11}{|l|}{ To depository institutions and } \\
\hline acceptances of other banks & .37 & .38 & .37 & .37 & .25 & .13 & .14 & .14 & .27 & .19 \\
\hline Foreign governments .......... & .03 & .03 & .02 & .02 & .01 & $*$ & $*$ & * & $*$ & $*$ \\
\hline Agricultural production..$\ldots \ldots$. & .82 & .85 & .86 & .83 & .82 & .81 & .84 & .88 & .90 & .92 \\
\hline Other loans.............. & 1.22 & 1.22 & 1.18 & 1.25 & 1.32 & 1.36 & 1.20 & 1.22 & 1.37 & 1.47 \\
\hline Lease-financing receivables.... & .75 & .74 & .75 & .67 & .75 & .75 & .75 & .65 & .65 & .49 \\
\hline LESS: Unearned income on loans. & -.08 & -.07 & -.06 & -.06 & -.06 & -.06 & -.06 & -.06 & -.06 & -.07 \\
\hline LEss: Loss reserves ${ }^{2} \ldots \ldots \ldots \ldots$ & -1.04 & -1.12 & -1.10 & -1.02 & -.98 & -.90 & -.88 & -.91 & -1.12 & -1.43 \\
\hline Securities............. & 24.34 & 22.81 & 23.86 & 24.36 & 23.59 & 21.57 & 19.55 & 18.30 & 16.96 & 17.28 \\
\hline Investment account & 24.25 & 22.70 & 23.80 & 24.23 & 23.54 & 21.50 & 19.47 & 18.10 & 16.80 & 17.19 \\
\hline Debt............... & 23.46 & 22.28 & 23.30 & 23.79 & 23.18 & 21.21 & 19.20 & 17.69 & 16.27 & 16.72 \\
\hline U.S. Treasury .............. & 1.81 & 1.32 & 1.22 & 1.00 & 1.02 & .83 & .59 & .47 & .36 & .48 \\
\hline $\begin{array}{l}\text { U.S. government agency and } \\
\text { corporation obligations } \ldots \ldots \ldots \ldots\end{array}$ & 15.56 & 14.70 & 15.85 & 16.96 & 16.70 & 15.05 & \multicolumn{2}{|c|}{ U.S. government agency and } & 11.32 & 11.53 \\
\hline Government-backed mortgage pools & 6.22 & 6.27 & $\begin{array}{r}1.85 \\
6.55\end{array}$ & $\begin{array}{r}10.90 \\
7.03\end{array}$ & $\begin{array}{r}10.10 \\
6.80\end{array}$ & $\begin{array}{r}15.05 \\
5.73\end{array}$ & $\begin{array}{r}13.53 \\
4.83\end{array}$ & $\begin{array}{r}12.32 \\
4.57\end{array}$ & $\begin{array}{r}11.32 \\
5.24\end{array}$ & $\begin{array}{r}11.53 \\
5.34\end{array}$ \\
\hline Collateralized mortgage obligations. & 3.04 & 3.08 & 3.69 & 3.69 & 3.41 & 3.16 & 2.81 & 2.60 & 2.42 & 2.81 \\
\hline 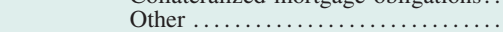 & 6.30 & 5.35 & 5.60 & 6.24 & 6.49 & 6.16 & 5.90 & 5.15 & 3.66 & 3.39 \\
\hline State and local government............ & 2.91 & 2.90 & 2.89 & 2.95 & 2.92 & 2.78 & 2.74 & 2.77 & 2.73 & 2.90 \\
\hline Private mortgage-backed securities... & .99 & .94 & .99 & .87 & 1.08 & 1.17 & 1.08 & 1.01 & .86 & .83 \\
\hline 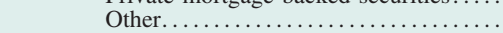 & 2.19 & 2.42 & 2.34 & 2.01 & 1.46 & 1.37 & 1.24 & 1.12 & 1.00 & .98 \\
\hline Equity $\ldots \ldots \ldots \ldots \ldots \ldots \ldots \ldots \ldots$ & .79 & .43 & .50 & .43 & .36 & .29 & .27 & .41 & .53 & .47 \\
\hline Trading account $\ldots \ldots \ldots \ldots \ldots \ldots \ldots \ldots$ & .09 & .11 & .06 & .14 & .05 & .08 & .07 & .20 & .17 & .09 \\
\hline Gross federal funds sold and reverse RPs.. & 3.40 & 4.20 & 4.15 & 3.85 & 2.95 & 2.83 & 2.81 & 2.57 & 2.01 & 1.46 \\
\hline Balances at depositories 1 . . . . . . . . . . & 1.60 & 1.68 & 1.89 & 1.81 & 1.69 & 1.76 & 1.67 & 1.57 & 1.78 & 4.88 \\
\hline Noninterest-earning assets ${ }^{1} \ldots \ldots \ldots \ldots \ldots \ldots$ & 8.50 & 8.84 & 8.64 & 8.66 & 8.44 & 8.68 & 8.93 & 8.72 & 8.72 & 8.70 \\
\hline Revaluation gains held in trading accounts & .02 & .01 & .01 & $*$ & $*$ & $*$ & .03 & .04 & .06 & .03 \\
\hline Other................................. & 8.49 & 8.84 & 8.64 & 8.66 & 8.44 & 8.68 & 8.90 & 8.67 & 8.66 & 8.67 \\
\hline Liabilities........ & 90.95 & 90.32 & 89.93 & 89.68 & 89.18 & 89.10 & 89.01 & 88.87 & 89.24 & 89.52 \\
\hline Core deposits ............... & 60.80 & 60.33 & 61.26 & 61.30 & 60.39 & 59.03 & 58.04 & 59.68 & 58.94 & 60.49 \\
\hline Transaction deposits $\ldots \ldots \ldots \ldots \ldots \ldots$ & 12.29 & 11.48 & 11.37 & 11.50 & 11.77 & 11.15 & 9.82 & 8.43 & 7.74 & 8.27 \\
\hline Demand deposits .................. & 8.97 & 8.23 & 8.05 & 7.96 & 8.12 & 7.87 & 6.99 & 5.94 & 5.32 & 5.51 \\
\hline Other checkable deposits ............. & 3.32 & 3.25 & 3.32 & 3.54 & 3.64 & 3.28 & 2.83 & 2.49 & 2.42 & 2.76 \\
\hline Savings deposits (including MMDAs) .... & 28.55 & 29.40 & 32.34 & 34.00 & 34.42 & 33.75 & 32.82 & 32.89 & 31.04 & 31.67 \\
\hline Small time deposits .................... & 19.96 & 19.46 & 17.55 & 15.80 & 14.21 & 14.13 & 15.41 & 18.36 & 20.15 & 20.55 \\
\hline Managed liabilities $^{3} \ldots \ldots \ldots \ldots \ldots \ldots \ldots$ & 28.01 & 27.75 & 26.57 & 26.40 & 26.98 & 28.38 & 29.32 & 27.51 & 28.72 & 27.21 \\
\hline Large time deposits ........ & 11.98 & 12.60 & 12.17 & 11.92 & 12.12 & 13.64 & 15.21 & 14.42 & 14.13 & 15.21 \\
\hline Deposits booked in foreign offices ....... & 1.28 & 1.24 & .88 & .64 & .65 & .57 & .52 & .57 & .72 & .60 \\
\hline Subordinated notes and debentures ...... & .30 & .31 & .34 & .35 & .35 & .27 & .24 & .22 & .21 & .16 \\
\hline Gross federal funds purchased and RPs... & 6.30 & 5.77 & 5.27 & 5.35 & 5.52 & 5.54 & 5.40 & 5.33 & 5.26 & 4.06 \\
\hline 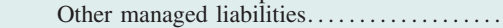 & 8.15 & 7.84 & 7.90 & 8.13 & 8.34 & 8.35 & 7.94 & 6.97 & 8.39 & 7.18 \\
\hline Revaluation losses held in trading accounts. . & $*$ & .01 & .01 & * & $*$ & $*$ & .01 & .01 & .02 & .02 \\
\hline 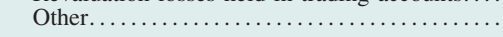 & 2.13 & 2.23 & 2.08 & 1.98 & 1.81 & 1.69 & 1.64 & 1.66 & 1.57 & 1.80 \\
\hline Capital account & 9.05 & 9.68 & 10.07 & 10.32 & 10.82 & 10.90 & 10.99 & 11.13 & 10.76 & 10.48 \\
\hline \multicolumn{11}{|l|}{ Мемо } \\
\hline Commercial real estate loans ${ }^{4}$. . & 19.32 & 21.03 & 23.05 & 24.62 & 27.28 & 29.84 & 32.22 & 34.52 & 35.86 & 34.51 \\
\hline Other real estate owned ${ }^{5} \ldots \ldots$. & 0.07 & 0.08 & 0.10 & 0.11 & 0.10 & 0.08 & 0.08 & 0.11 & 0.27 & 0.62 \\
\hline Mortgage-backed securities ........... & 10.25 & 10.29 & 11.24 & 11.59 & 11.29 & 10.06 & 8.72 & 8.18 & 8.52 & 8.97 \\
\hline Federal Home Loan Bank advances .... & n.a. & 5.27 & 5.71 & 6.29 & 6.46 & 6.42 & 6.11 & 5.53 & 7.04 & 5.97 \\
\hline Balances at the Federal Reserve ${ }^{1} \ldots \ldots$. & 0.57 & 0.54 & 0.52 & 0.59 & 0.55 & 0.47 & 0.36 & 0.29 & 1.46 & 3.34 \\
\hline Interest-earning $\ldots \ldots \ldots \ldots \ldots \ldots \ldots$ & n.a. & n.a. & n.a. & n.a. & n.a. & n.a. & n.a. & n.a. & 1.15 & 3.34 \\
\hline & 0.57 & 0.54 & 0.52 & 0.59 & 0.55 & 0.47 & 0.36 & 0.29 & 0.31 & n.a. \\
\hline \multicolumn{11}{|l|}{ Interest-earning balances at depositories } \\
\hline other than the Federal Reserve .... & 1.60 & 1.68 & 1.89 & 1.81 & 1.69 & 1.76 & 1.67 & 1.57 & 1.54 & 1.53 \\
\hline $\begin{array}{l}\text { Average net consolidated assets } \\
\text { (billions of dollars) } \ldots \ldots \ldots \ldots\end{array}$ & 986 & 1,002 & 1,022 & 1,072 & 1,080 & 1,152 & 1,249 & 1,267 & 1,278 & 1,312 \\
\hline
\end{tabular}


A.1. Portfolio composition, interest rates, and income and expense, U.S. banks, 2000-09—Continued

D. Banks ranked 101 through 1,000 by assets-Continued

\begin{tabular}{|c|c|c|c|c|c|c|c|c|c|c|}
\hline Item & 2000 & 2001 & 2002 & 2003 & 2004 & 2005 & 2006 & 2007 & 2008 & 2009 \\
\hline & \multicolumn{10}{|c|}{ Effective interest rate (percent) ${ }^{6}$} \\
\hline \multicolumn{11}{|l|}{ Rates earned } \\
\hline Interest-earning assets $\ldots$. & 8.48 & 7.85 & 6.42 & 5.59 & 5.46 & 6.12 & 7.01 & 7.31 & 6.24 & 5.22 \\
\hline Taxable equivalent & 8.56 & 7.94 & 6.50 & 5.67 & 5.53 & 6.19 & 7.08 & 7.38 & 6.30 & 5.28 \\
\hline Loans and leases, gross ... & 9.42 & 8.76 & 7.31 & 6.56 & 6.25 & 6.90 & 7.79 & 8.02 & 6.72 & 5.81 \\
\hline Net of loss provisions & 8.75 & 7.87 & 6.55 & 6.01 & 5.87 & 6.64 & 7.55 & 7.44 & 5.04 & 3.15 \\
\hline Securities................ & 6.45 & 5.96 & 4.95 & 3.81 & 3.79 & 4.03 & 4.53 & 4.86 & 4.76 & 4.20 \\
\hline Taxable equivalent & 6.71 & 6.24 & 5.21 & 4.06 & 4.04 & 4.28 & 4.80 & 5.14 & 5.01 & 4.43 \\
\hline Investment account $\ldots \ldots \ldots \ldots \ldots \ldots$ & 6.45 & 5.95 & 4.93 & 3.82 & 3.78 & 4.02 & 4.53 & 4.85 & 4.76 & 4.20 \\
\hline \multicolumn{11}{|l|}{$\begin{array}{l}\text { U.S. Treasury securities and U.S. } \\
\text { government agency obligations }\end{array}$} \\
\hline (excluding MBS) …........... & n.a. & 5.85 & 4.54 & 3.42 & 3.15 & 3.47 & 4.19 & 4.74 & 4.45 & 3.19 \\
\hline Mortgage-backed securities . & n.a. & 6.33 & 5.38 & 3.95 & 4.01 & 4.23 & 4.64 & 4.96 & 5.09 & 4.75 \\
\hline Other .................... & n.a. & 5.40 & 4.51 & 4.07 & 4.21 & 4.42 & 4.81 & 4.81 & 4.42 & 3.97 \\
\hline Trading account $\ldots \ldots \ldots \ldots \ldots \ldots \ldots \ldots \ldots \ldots \ldots \ldots \ldots \ldots \ldots \ldots \ldots \ldots$ & 9.30 & 6.60 & 14.05 & 3.07 & 10.30 & 6.59 & 4.92 & 5.25 & 4.44 & 4.17 \\
\hline Gross federal funds sold and reverse RPs & 6.15 & 3.91 & 1.73 & 1.27 & 1.57 & 3.31 & 4.94 & 4.87 & 2.12 & .50 \\
\hline Interest-bearing balances at depositories ${ }^{1}$. & 5.76 & 3.93 & 1.79 & 1.26 & 1.47 & 3.29 & $\begin{array}{l}4.94 \\
4.60\end{array}$ & $\begin{array}{l}4.81 \\
4.56\end{array}$ & 2.21 & .34 \\
\hline \multicolumn{11}{|l|}{ Rates paid } \\
\hline Interest-bearing liabilities .. & 4.79 & 3.97 & 2.45 & 1.80 & 1.65 & 2.36 & 3.38 & 3.78 & 2.79 & 1.92 \\
\hline Interest-bearing deposits. & 4.46 & 3.81 & 2.28 & 1.61 & 1.44 & 2.09 & 3.11 & 3.59 & 2.72 & 1.85 \\
\hline In foreign offices ..... & 6.13 & 4.27 & 2.14 & 1.43 & 1.43 & 3.05 & 4.50 & 4.63 & 2.29 & .59 \\
\hline In domestic offices............ & 4.43 & 3.81 & 2.28 & 1.61 & 1.44 & 2.08 & 3.10 & 3.58 & 2.72 & 1.86 \\
\hline Other checkable deposits ............... & 2.27 & 1.81 & 1.06 & .74 & .72 & 1.18 & 1.74 & 1.89 & 1.17 & .71 \\
\hline Savings deposits (including MMDAs) . & 3.07 & 2.22 & 1.17 & .75 & .74 & 1.27 & 2.06 & 2.38 & 1.39 & .78 \\
\hline Large time deposits................. & 6.00 & 5.27 & 3.32 & 2.58 & 2.33 & 3.21 & 4.42 & 4.90 & 3.91 & 2.71 \\
\hline Other time deposits. . & 5.74 & 5.51 & 3.77 & 2.86 & 2.51 & 3.10 & 4.19 & 4.83 & 4.03 & 2.97 \\
\hline Gross federal funds purchased and RPs & 5.95 & 3.82 & 1.83 & 1.29 & 1.45 & 2.94 & 4.52 & 4.49 & 2.30 & 1.15 \\
\hline Other interest-bearing liabilities......... & 6.46 & 5.32 & 4.22 & 3.57 & 3.37 & 4.02 & 4.75 & 5.04 & 3.65 & 3.11 \\
\hline & \multicolumn{10}{|c|}{ Income and expense as a percentage of average net consolidated assets } \\
\hline Gross interest income... & 7.79 & 7.16 & 5.84 & 5.07 & 4.99 & 5.57 & 6.40 & 6.67 & 5.71 & 4.78 \\
\hline Taxable equivalent.. & 7.86 & 7.23 & 5.91 & 5.15 & 5.06 & 5.64 & 6.46 & 6.74 & 5.76 & 4.82 \\
\hline Loans ................ & 5.96 & 5.59 & 4.56 & 4.07 & 4.01 & 4.55 & 5.29 & 5.58 & 4.80 & 4.01 \\
\hline Securities................................... & 1.58 & 1.33 & 1.15 & .91 & .88 & .86 & .89 & .88 & .80 & .72 \\
\hline Gross federal funds sold and reverse RPs & .21 & .16 & .07 & .05 & .05 & .09 & .14 & .12 & .04 & .01 \\
\hline 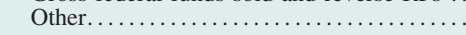 & .04 & .08 & .06 & .05 & .05 & .07 & .09 & .09 & .06 & .04 \\
\hline Gross interest expense. & 3.79 & 3.14 & 1.92 & 1.41 & 1.29 & 1.84 & 2.67 & 3.00 & 2.24 & 1.55 \\
\hline Deposits........................................... & 2.87 & 2.48 & 1.49 & 1.04 & .92 & 1.34 & 2.04 & 2.41 & 1.81 & 1.28 \\
\hline Gross federal funds purchased and RPs & .38 & .22 & .09 & .07 & .08 & .16 & .24 & .24 & .12 & .05 \\
\hline 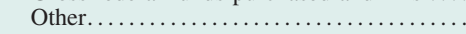 & .54 & .44 & .34 & .30 & .29 & .34 & .39 & .36 & .31 & .23 \\
\hline Net interest income..... & 4.00 & 4.02 & 3.92 & 3.67 & 3.70 & 3.73 & 3.73 & 3.67 & 3.47 & 3.22 \\
\hline Taxable equivalent. & 4.07 & 4.10 & 3.99 & 3.74 & 3.77 & 3.79 & 3.79 & 3.73 & 3.52 & 3.27 \\
\hline Loss provisions $^{7} \ldots \ldots \ldots$ & .52 & .65 & .54 & .40 & .30 & .24 & .23 & .47 & 1.25 & 1.88 \\
\hline Noninterest income........... & 2.35 & 2.37 & 2.36 & 2.30 & 2.26 & 2.02 & 1.98 & 1.88 & 1.52 & 1.57 \\
\hline Service charges on deposits. & .36 & .39 & .41 & .41 & .39 & .36 & .35 & .36 & .36 & .34 \\
\hline Fiduciary activities........... & .44 & .40 & .35 & .34 & .37 & .35 & .30 & .31 & .31 & .27 \\
\hline Trading revenue ......... & .01 & $*$ & $*$ & .01 & .01 & .01 & .01 & .01 & -.01 & .02 \\
\hline Interest rate exposures . . . . . . . . & .01 & -.01 & * & .01 & .01 & .01 & * & $*$ & $*$ & * \\
\hline Foreign exchange rate exposures ........ & $*$ & $*$ & * & $*$ & * & $*$ & * & * & * & $*$ \\
\hline Other commodity and equity exposures & * & * & * & * & * & * & $*$ & * & -.01 & * \\
\hline 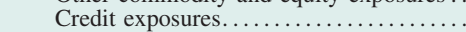 & n.a. & n.a. & n.a. & n.a. & n.a. & n.a. & n.a. & * & $*$ & .01 \\
\hline Other................... & 1.55 & 1.58 & 1.60 & 1.54 & 1.49 & 1.30 & 1.32 & 1.20 & .85 & .94 \\
\hline Noninterest expense $\ldots \ldots \ldots \ldots \ldots \ldots \ldots$ & 3.84 & 3.88 & 3.72 & 3.59 & 3.54 & 3.37 & 3.35 & 3.26 & 3.42 & 3.36 \\
\hline Salaries, wages, and employee benefits. & 1.59 & 1.61 & 1.64 & 1.64 & 1.64 & 1.61 & 1.59 & 1.57 & 1.46 & 1.42 \\
\hline Occupancy $\ldots \ldots \ldots \ldots \ldots \ldots \ldots \ldots \ldots \ldots \ldots$ & .47 & .46 & .45 & .43 & .43 & .41 & .40 & .40 & .39 & .39 \\
\hline Other. $\ldots \ldots \ldots \ldots \ldots \ldots \ldots \ldots \ldots \ldots$ & 1.78 & 1.81 & 1.63 & 1.53 & 1.48 & 1.36 & 1.35 & 1.28 & 1.58 & 1.55 \\
\hline Net noninterest expense $\ldots \ldots \ldots \ldots \ldots \ldots \ldots$ & 1.48 & 1.52 & 1.35 & 1.29 & 1.29 & 1.35 & 1.36 & 1.38 & 1.90 & 1.79 \\
\hline Gains on investment account securities ...... & -.04 & .05 & .04 & .05 & .02 & -.01 & -.01 & -.01 & -.22 & -.02 \\
\hline 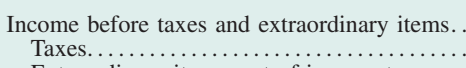 & $\begin{array}{r}1.96 \\
.67\end{array}$ & $\begin{array}{r}1.90 \\
.66\end{array}$ & $\begin{array}{r}2.07 \\
.67\end{array}$ & $\begin{array}{r}2.02 \\
.66\end{array}$ & $\begin{array}{r}2.13 \\
.68\end{array}$ & $\begin{array}{r}2.13 \\
.68\end{array}$ & $\begin{array}{r}2.13 \\
.69\end{array}$ & $\begin{array}{r}1.81 \\
.57\end{array}$ & $\begin{array}{l}.09 \\
.14\end{array}$ & -.47 \\
\hline Extraordinary items, net of income taxes.. & * & .01 & $*$ & .03 & $*$ & * & * & & & * \\
\hline Net income $(\ldots, \ldots \ldots \ldots \ldots \ldots \ldots$ & 1.29 & 1.25 & 1.39 & 1.39 & 1.45 & 1.45 & 1.43 & 1.23 & -.05 & -.47 \\
\hline Cash dividends declared. . & .92 & 1.33 & 1.19 & 1.64 & .78 & .87 & .90 & .91 & .57 & .34 \\
\hline Retained income .......... & .37 & -.08 & .20 & -.25 & .68 & .58 & .54 & .32 & -.62 & -.80 \\
\hline Мемо: Return on equity $\ldots \ldots \ldots \ldots \ldots \ldots$ & 14.21 & 12.93 & 13.83 & 13.46 & 13.42 & 13.33 & 13.05 & 11.08 & -.50 & -4.48 \\
\hline
\end{tabular}

NotE: Data are as of March 23, 2010

1. Effective October 1, 2008, the Federal Reserve began paying interest on depository institutions' required and excess reserve balances. Beginning with the 2008:Q4 Call Report, balances due from Federal Reserve Banks are now reported under "Interest-earning assets" rather than "Noninterest-earning assets."

2. Includes allocated transfer risk reserve.

3. Measured as the sum of large time deposits in domestic offices, deposits booked in foreign offices, subordinated notes and debentures, federal funds purchased and securities sold under repurchase agreements, Federal Home Loan Bank advances, and other borrowed money.

4. Measured as the sum of construction and land development loans secured by real estate; real estate loans secured by nonfarm nonresidential properties or by multifamily residential properties; and loans to finance commercial real estate, construction, and land development activities not secured by real estate.

5. Other real estate owned is a component of other noninterest-earning assets

6 . When possible, based on the average of quarterly balance sheet data reported on schedule RC-K of the quarterly Call Report.

7. Includes provisions for allocated transfer risk.

* In absolute value, less than 0.005 percent.

n.a. Not available.

MMDA Money market deposit account.

RP Repurchase agreement.

MBS Mortgage-backed securities 
A.1. Portfolio composition, interest rates, and income and expense, U.S. banks, 2000-09

E. Banks not ranked among the 1,000 largest by assets

\begin{tabular}{|c|c|c|c|c|c|c|c|c|c|c|}
\hline Item & 2000 & 2001 & 2002 & 2003 & 2004 & 2005 & 2006 & 2007 & 2008 & 2009 \\
\hline & \multicolumn{10}{|c|}{ Balance sheet items as a percentage of average net consolidated assets } \\
\hline Interest-earning assets ${ }^{1} \ldots$ & 92.52 & 92.30 & 92.27 & 92.16 & 92.34 & 92.29 & 92.36 & 92.39 & 92.15 & 92.42 \\
\hline Loans and leases (net)....... & 62.31 & 62.67 & 62.72 & 62.32 & 63.80 & 65.43 & 66.65 & 67.29 & 67.82 & 66.55 \\
\hline Commercial and industrial & 11.09 & 11.10 & 10.71 & 10.42 & 10.29 & 10.21 & 10.17 & 10.25 & 10.34 & 9.72 \\
\hline U.S. addressees $\ldots \ldots \ldots$ & 11.02 & 11.02 & 10.65 & 10.37 & 10.25 & 10.15 & 10.12 & 10.21 & 10.30 & 9.68 \\
\hline Foreign addressees. & .07 & .07 & .06 & .05 & .04 & .05 & .04 & .04 & .04 & .05 \\
\hline Consumer ............ & 7.98 & 7.42 & 6.77 & 6.16 & 5.45 & 4.97 & 4.63 & 4.36 & 4.07 & 3.77 \\
\hline Credit card............ & .59 & .59 & .49 & .51 & .40 & .36 & .37 & .37 & .35 & .31 \\
\hline Installment and other . & 7.39 & 6.83 & 6.28 & 5.64 & 5.05 & 4.61 & 4.25 & 3.99 & 3.72 & 3.46 \\
\hline Real estate ............. & 39.29 & 40.30 & 41.52 & 42.30 & 44.75 & 46.97 & 48.54 & 49.28 & 50.10 & 49.93 \\
\hline In domestic offices $\ldots \ldots \ldots \ldots \ldots \ldots$ & 39.29 & 40.30 & 41.52 & 42.30 & 44.74 & 46.97 & 48.53 & 49.28 & 50.10 & 49.93 \\
\hline Construction and land development & 3.70 & 4.23 & 4.51 & 4.99 & 6.01 & 7.46 & 9.10 & 10.01 & 9.64 & 7.80 \\
\hline Farmland $\ldots \ldots \ldots \ldots \ldots \ldots \ldots \ldots$ & 3.06 & 3.04 & 3.08 & 3.13 & 3.22 & 3.25 & 3.26 & 3.38 & 3.49 & 3.64 \\
\hline One- to four-family residential. . & 18.43 & 18.24 & 17.91 & 17.08 & 17.17 & 17.12 & 16.69 & 16.31 & 16.64 & 17.29 \\
\hline Home equity $\ldots \ldots \ldots \ldots \ldots$ & 1.28 & 1.37 & 1.62 & 1.79 & 2.11 & 2.20 & 2.06 & 2.01 & 2.11 & 2.29 \\
\hline Other $\ldots \ldots \ldots \ldots \ldots$ & 17.15 & 16.87 & 16.29 & 15.29 & 15.06 & 14.93 & 14.63 & 14.30 & 14.52 & 15.01 \\
\hline Multifamily residential. & 1.04 & 1.06 & 1.16 & 1.28 & 1.41 & 1.48 & 1.47 & 1.50 & 1.61 & 1.76 \\
\hline Nonfarm nonresidential & 13.06 & 13.71 & 14.86 & 15.82 & 16.94 & 17.66 & 18.01 & 18.09 & 18.73 & 19.43 \\
\hline In foreign offices .............. & $*$ & * & * & $*$ & $*$ & $*$ & $*$ & * & $*$ & * \\
\hline \multicolumn{11}{|l|}{ To depository institutions and } \\
\hline Foreign governments ........... & .01 & $*$ & $*$ & $* 9$ & $* 1$ & $* 05$ & * & $* 06$ & $* 06$ & $* 06$ \\
\hline Agricultural production ......... & 3.85 & 3.76 & 3.64 & 3.40 & 3.26 & 3.21 & 3.22 & 3.26 & 3.24 & 3.20 \\
\hline Other loans................ & .69 & .67 & .65 & .66 & .68 & .70 & .70 & .70 & .73 & .75 \\
\hline Lease-financing receivables $\ldots \ldots \ldots$ & .27 & .27 & .31 & .26 & .25 & .24 & .26 & .27 & .26 & .24 \\
\hline LEss: Unearned income on loans ... & -.11 & -.09 & -.07 & -.06 & -.06 & -.05 & -.05 & -.04 & -.04 & -.04 \\
\hline LESS: Loss reserves ${ }^{2} \ldots \ldots \ldots \ldots$ & -.88 & -.88 & -.90 & -.92 & -.89 & -.87 & -.87 & -.87 & -.93 & -1.09 \\
\hline Securities............ & 25.40 & 22.80 & 23.34 & 23.47 & 23.34 & 21.92 & 20.54 & 19.65 & 19.20 & 19.22 \\
\hline Investment account & 25.38 & 22.79 & 23.33 & 23.43 & 23.34 & 21.91 & 20.52 & 19.58 & 19.16 & 19.18 \\
\hline Debt.............. & 24.82 & 22.49 & 23.05 & 23.12 & 23.07 & 21.70 & 20.35 & 19.41 & 18.97 & 19.00 \\
\hline U.S. Treasury ............. & 2.12 & 1.33 & 1.04 & .90 & .81 & .71 & .61 & .47 & .33 & .37 \\
\hline \multicolumn{11}{|l|}{ U.S. government agency and } \\
\hline $\begin{array}{l}\text { corporation obligations ............ } \\
\text { Government-backed mortgage pools }\end{array}$ & $\begin{array}{r}16.95 \\
3.47\end{array}$ & $\begin{array}{r}15.21 \\
3.78\end{array}$ & $\begin{array}{r}16.07 \\
4.54\end{array}$ & $\begin{array}{r}16.23 \\
4.84\end{array}$ & $\begin{array}{r}16.57 \\
4.76\end{array}$ & $\begin{array}{r}15.64 \\
4.23\end{array}$ & $\begin{array}{r}14.73 \\
3.62\end{array}$ & $\begin{array}{r}14.01 \\
3.55\end{array}$ & $\begin{array}{r}13.44 \\
4.80\end{array}$ & $\begin{array}{r}13.12 \\
5.15\end{array}$ \\
\hline Collateralized mortgage obligations. & 1.70 & 1.94 & 2.30 & 2.20 & 1.96 & 1.71 & 1.50 & 1.55 & 1.76 & 1.88 \\
\hline Other $\ldots \ldots \ldots \ldots \ldots \ldots \ldots \ldots \ldots$ & 11.78 & 9.56 & 9.23 & 9.19 & 9.85 & 9.70 & 9.61 & 8.92 & 6.88 & 6.09 \\
\hline State and local government......... & 4.64 & 4.51 & 4.56 & 4.73 & 4.67 & 4.49 & 4.30 & 4.20 & 4.24 & 4.52 \\
\hline Private mortgage-backed securities.... & .23 & .27 & .26 & .21 & .19 & .22 & .24 & .29 & .47 & .48 \\
\hline Other. $\ldots \ldots \ldots \ldots \ldots \ldots \ldots \ldots \ldots \ldots$ & .88 & 1.11 & 1.12 & 1.05 & .83 & .65 & .48 & .43 & .49 & .51 \\
\hline Equity $\ldots \ldots \ldots \ldots \ldots \ldots \ldots \ldots$ & .56 & .30 & .27 & .31 & .26 & .20 & .17 & .17 & .19 & .18 \\
\hline Trading account $\ldots \ldots \ldots \ldots \ldots \ldots \ldots \ldots$ & .02 & .01 & .01 & .04 & .01 & .02 & .02 & .07 & .04 & .03 \\
\hline Gross federal funds sold and reverse RPs ... & 3.22 & 5.01 & 4.26 & 4.27 & 3.33 & 3.24 & 3.53 & 3.92 & 3.29 & 2.44 \\
\hline Balances at depositories ${ }^{1} \ldots \ldots \ldots \ldots \ldots$ & 1.59 & 1.82 & 1.95 & 2.11 & 1.86 & 1.69 & 1.64 & 1.54 & 1.84 & 4.21 \\
\hline \multirow{2}{*}{\multicolumn{11}{|c|}{ Noninterest-earning assets ${ }^{1} \ldots \ldots \ldots \ldots \ldots$}} \\
\hline Revaluation gains held in trading accounts. & $*$ & $*$ & & & & & & & & \\
\hline 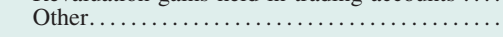 & 7.48 & 7.70 & 7.73 & 7.84 & 7.66 & 7.71 & 7.64 & 7.61 & 7.85 & 7.58 \\
\hline Liabilities........ & 89.88 & 89.59 & 89.73 & 89.58 & 89.55 & 89.49 & 89.35 & 88.95 & 89.12 & 89.53 \\
\hline Core deposits ............. & 70.87 & 69.92 & 70.04 & 69.96 & 69.24 & 67.68 & 65.74 & 65.12 & 64.28 & 64.35 \\
\hline Transaction deposits & 23.20 & 22.35 & 22.66 & 23.18 & 23.36 & 22.72 & 20.81 & 18.66 & 17.75 & 17.99 \\
\hline Demand deposits .......... & 12.64 & 12.16 & 12.24 & 12.58 & 12.77 & 12.77 & 11.97 & 10.73 & 10.07 & 9.87 \\
\hline Other checkable deposits $\ldots \ldots \ldots \ldots$ & 10.57 & 10.19 & 10.42 & 10.60 & 10.59 & 9.95 & 8.84 & 7.93 & 7.68 & 8.12 \\
\hline Savings deposits (including MMDAs) .. & 19.19 & 19.38 & 21.32 & 22.43 & 23.24 & 22.98 & 22.66 & 22.68 & 22.56 & 23.08 \\
\hline Small time deposits . . . . . . . . . . . . . . . & 28.48 & 28.20 & 26.05 & 24.36 & 22.64 & 21.98 & 22.28 & 23.78 & 23.97 & 23.28 \\
\hline Managed liabilities $^{3} \ldots$ & 18.08 & 18.67 & 18.79 & 18.78 & 19.57 & 21.04 & 22.76 & 22.92 & 24.02 & 24.42 \\
\hline Large time deposits................ & 12.51 & 13.55 & 13.21 & 13.07 & 13.15 & 14.53 & 16.49 & 16.91 & 16.64 & 17.79 \\
\hline Deposits booked in foreign offices...... & .05 & .06 & .07 & .06 & .07 & .06 & .06 & .05 & .06 & .05 \\
\hline Subordinated notes and debentures ..... & .02 & .02 & .04 & .03 & .04 & .03 & .03 & .03 & .03 & .03 \\
\hline Gross federal funds purchased and RPs. & 2.06 & 1.55 & 1.51 & 1.52 & 1.76 & 1.74 & 1.82 & 1.82 & 1.87 & 1.49 \\
\hline Other managed liabilities................. & 3.44 & 3.49 & 3.96 & 4.09 & 4.54 & 4.68 & 4.36 & 4.11 & 5.41 & 5.06 \\
\hline Revaluation losses held in trading accounts. . & $*$ & $*$ & * & $*$ & $*$ & $*$ & $*$ & * & * & * \\
\hline 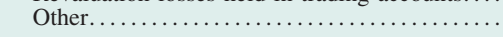 & .93 & 1.00 & .90 & .84 & .74 & .77 & .84 & .91 & .82 & .76 \\
\hline Capital account & 10.12 & 10.41 & 10.27 & 10.42 & 10.45 & 10.51 & 10.65 & 11.05 & 10.88 & 10.47 \\
\hline \multicolumn{11}{|l|}{ МЕмо } \\
\hline Commercial real estate loans ${ }^{4}$. & 17.91 & 19.15 & 20.67 & 22.23 & 24.50 & 26.77 & 28.81 & 29.88 & 30.34 & 29.28 \\
\hline Other real estate owned ${ }^{5} \ldots \ldots$ & .11 & .12 & .14 & .15 & .14 & .13 & .12 & .16 & .35 & .70 \\
\hline Mortgage-backed securities .......... & 5.39 & 5.99 & 7.10 & 7.25 & 6.91 & 6.16 & 5.36 & 5.39 & 7.03 & 7.51 \\
\hline Federal Home Loan Bank advances ... & n.a. & 3.34 & 3.71 & 3.87 & 4.32 & 4.46 & 4.14 & 3.93 & 5.20 & 4.78 \\
\hline Balances at the Federal Reserve ${ }^{1} \ldots$ & .93 & .76 & .79 & .87 & .78 & .70 & .57 & .45 & 1.26 & 2.09 \\
\hline Interest-earning $\ldots \ldots \ldots \ldots \ldots$ & n.a. & n.a. & n.a. & n.a. & n.a. & n.a. & n.a. & n.a. & .82 & 2.09 \\
\hline & .93 & .76 & .79 & .87 & .78 & .70 & .57 & .45 & .45 & n.a. \\
\hline \multicolumn{11}{|l|}{ Interest-earning balances at depositories } \\
\hline other than the Federal Reserve .... & 1.59 & 1.82 & 1.95 & 2.11 & 1.86 & 1.69 & 1.64 & 1.54 & 1.71 & 2.12 \\
\hline $\begin{array}{l}\text { Average net consolidated assets } \\
\text { (billions of dollars) } \ldots \ldots \ldots \ldots \ldots\end{array}$ & 655 & 675 & 704 & 742 & 768 & 805 & 840 & 862 & 882 & 897 \\
\hline
\end{tabular}


A.1. Portfolio composition, interest rates, and income and expense, U.S. banks, 2000-09—Continued

E. Banks not ranked among the 1,000 largest by assets-Continued

\begin{tabular}{|c|c|c|c|c|c|c|c|c|c|c|}
\hline Item & 2000 & 2001 & 2002 & 2003 & 2004 & 2005 & 2006 & 2007 & 2008 & 2009 \\
\hline & & & & Eff & ive inter & rate (pe & $n t)^{6}$ & & & \\
\hline \multicolumn{11}{|l|}{ Rates earned } \\
\hline Interest-earning assets $\ldots \ldots \ldots \ldots \ldots \ldots \ldots \ldots$ & 8.44 & 7.92 & 6.79 & 5.94 & 5.73 & 6.23 & 7.01 & 7.26 & 6.34 & 5.53 \\
\hline Taxable equivalent $\ldots \ldots \ldots \ldots \ldots \ldots \ldots$ & 8.56 & 8.03 & 6.90 & 6.05 & 5.84 & 6.33 & 7.10 & 7.35 & 6.42 & 5.61 \\
\hline Loans and leases, gross ........ & 9.51 & 9.01 & 7.83 & 7.08 & 6.72 & 7.17 & 7.94 & 8.13 & 7.03 & 6.32 \\
\hline Net of loss provisions $\ldots \ldots \ldots \ldots \ldots$ & 9.14 & 8.60 & 7.39 & 6.72 & 6.45 & 6.94 & 7.74 & 7.81 & 6.12 & 4.87 \\
\hline Securities....................... & 6.15 & 5.86 & 5.03 & 3.87 & 3.74 & 3.87 & 4.28 & 4.68 & 4.70 & 4.17 \\
\hline 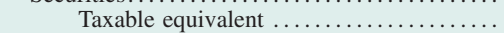 & 6.54 & 6.27 & 5.43 & 4.26 & 4.11 & 4.24 & 4.65 & 5.05 & 5.04 & 4.51 \\
\hline Investment account $\ldots \ldots \ldots \ldots \ldots \ldots$ & 6.15 & 5.86 & 5.02 & 3.87 & 3.73 & 3.86 & 4.28 & 4.68 & 4.70 & 4.16 \\
\hline $\begin{array}{l}\text { U.S. Treasury securities and U.S. } \\
\text { government agency obligations } \\
\text { (excluding MBS) } \ldots \ldots \ldots \ldots \ldots\end{array}$ & n.a. & 5.97 & 4.80 & 3.74 & 3.38 & 3.53 & 4.12 & 4.69 & 4.62 & 3.65 \\
\hline Mortgage-backed securities ................ & $\begin{array}{l}11 . a . \\
\text { n.a. }\end{array}$ & 6.20 & 5.47 & 3.58 & 3.90 & 4.17 & 4.59 & 4.96 & 5.08 & 4.67 \\
\hline Other $\ldots \ldots \ldots \ldots \ldots \ldots \ldots \ldots \ldots$ & n.a. & 5.29 & 4.87 & 4.43 & 4.18 & 4.16 & 4.25 & 4.33 & 4.28 & 4.07 \\
\hline 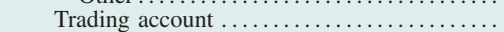 & 4.01 & 6.43 & 15.38 & 2.89 & 18.95 & 7.52 & 7.50 & 4.74 & 4.33 & 5.49 \\
\hline Gross federal funds sold and reverse RPs. & 6.24 & 3.82 & 1.63 & 1.08 & 1.32 & 3.21 & 4.95 & 5.05 & 2.17 & .31 \\
\hline Interest-bearing balances at depositories ${ }^{1}$.. & 6.38 & 4.56 & 2.68 & 1.97 & 2.02 & 3.21 & 4.64 & 5.06 & 3.03 & 1.15 \\
\hline \multicolumn{11}{|l|}{ Rates paid } \\
\hline Interest-bearing liabilities ................. & 4.84 & 4.43 & 2.93 & 2.14 & 1.88 & 2.44 & 3.42 & 3.91 & 3.06 & 2.16 \\
\hline Interest-bearing deposits . .............. & 4.67 & 4.31 & 2.78 & 2.02 & 1.75 & 2.29 & 3.28 & 3.81 & 2.99 & 2.07 \\
\hline In foreign offices $\ldots \ldots \ldots \ldots \ldots \ldots \ldots \ldots$ & 5.13 & 3.97 & 1.67 & .85 & 1.04 & 2.86 & 4.27 & 4.66 & 2.28 & .19 \\
\hline In domestic offices $\ldots \ldots \ldots \ldots \ldots \ldots \ldots \ldots$ & 4.67 & 4.31 & 2.78 & 2.02 & 1.75 & 2.29 & 3.28 & 3.80 & 2.99 & 2.07 \\
\hline Other checkable deposits ........... & 2.47 & 1.97 & 1.16 & .78 & .69 & .99 & 1.45 & 1.62 & 1.11 & .74 \\
\hline Savings deposits (including MMDAs). & 3.56 & 2.81 & 1.72 & 1.13 & 1.04 & 1.53 & 2.34 & 2.67 & 1.65 & 1.01 \\
\hline Large time deposits. . . . . . . . & 5.89 & 5.52 & 3.61 & 2.79 & 2.47 & 3.21 & 4.37 & 4.90 & 4.03 & 2.84 \\
\hline Other time deposits.................. & 5.70 & 5.60 & 3.88 & 2.96 & 2.55 & 3.04 & 4.12 & 4.79 & 4.06 & 2.99 \\
\hline Gross federal funds purchased and RPs ... & 5.69 & 3.92 & 1.85 & 1.31 & 1.45 & 2.89 & 4.37 & 4.46 & 2.35 & 1.10 \\
\hline Other interest-bearing liabilities.......... & 9.13 & 8.08 & 6.82 & 5.31 & 4.59 & 5.01 & 5.70 & 5.81 & 4.49 & 3.89 \\
\hline & \multicolumn{10}{|c|}{ Income and expense as a percentage of average net consolidated assets } \\
\hline Gross interest income................. & 7.83 & 7.33 & 6.31 & 5.46 & 5.32 & 5.78 & 6.49 & 6.73 & 5.87 & 5.12 \\
\hline Taxable equivalent................. & 7.95 & 7.44 & 6.41 & 5.56 & 5.41 & 5.87 & 6.58 & 6.82 & 5.94 & 5.19 \\
\hline Loans $\ldots \ldots \ldots \ldots \ldots \ldots \ldots \ldots \ldots \ldots \ldots \ldots \ldots \ldots$ & 5.99 & 5.73 & 5.01 & 4.47 & 4.35 & 4.76 & 5.35 & 5.53 & 4.83 & 4.27 \\
\hline Securities............................ & 1.57 & 1.32 & 1.16 & .89 & .87 & .85 & .88 & .92 & .90 & .79 \\
\hline Gross federal funds sold and reverse RPs . & .21 & .20 & .07 & .05 & .05 & .11 & .18 & .20 & .08 & .01 \\
\hline Other........................... & .05 & .08 & .06 & .06 & .05 & .06 & .08 & .08 & .07 & .05 \\
\hline Gross interest expense $\ldots \ldots \ldots \ldots \ldots \ldots \ldots \ldots$ & 3.64 & 3.33 & 2.22 & 1.60 & 1.41 & 1.82 & 2.56 & 2.95 & 2.33 & 1.67 \\
\hline 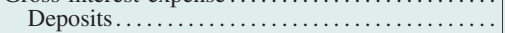 & 3.30 & 3.07 & 1.98 & 1.41 & 1.22 & 1.58 & 2.27 & 2.67 & 2.08 & 1.48 \\
\hline Gross federal funds purchased and RPs ....... & .12 & .06 & .03 & .02 & .02 & .05 & .08 & .08 & .04 & .02 \\
\hline 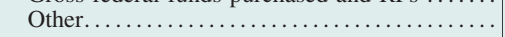 & .21 & .20 & .21 & .17 & .17 & .19 & .21 & .20 & .21 & .17 \\
\hline Net interest income................... & 4.20 & 4.00 & 4.08 & 3.86 & 3.91 & 3.96 & 3.94 & 3.79 & 3.54 & 3.45 \\
\hline Taxable equivalent... & 4.31 & 4.10 & 4.19 & 3.96 & 4.00 & 4.05 & 4.03 & 3.87 & 3.62 & 3.52 \\
\hline Loss provisions ${ }^{7} \ldots \ldots$. & .32 & .33 & .35 & .29 & .23 & .21 & .20 & .28 & .68 & 1.03 \\
\hline Noninterest income $\ldots \ldots \ldots \ldots \ldots \ldots \ldots$ & 1.31 & 1.30 & 1.39 & 1.47 & 1.38 & 1.33 & 1.31 & 1.33 & 1.18 & 1.01 \\
\hline 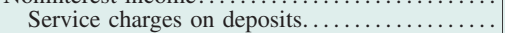 & .43 & .44 & .45 & .43 & .43 & .40 & .38 & .37 & .36 & .33 \\
\hline Fiduciary activities ..................... & .20 & .25 & .27 & .28 & .31 & .33 & .36 & .38 & .33 & .24 \\
\hline Trading revenue $\ldots \ldots \ldots \ldots \ldots \ldots \ldots \ldots \ldots \ldots \ldots$ & $*$ & $*$ & $* 21$ & $*$ & $*$ & $*$ & $*$ & $*$ & $*$ & $*$ \\
\hline Interest rate exposures $\ldots \ldots \ldots \ldots \ldots$ & $*$ & * & $*$ & $*$ & $*$ & $*$ & $*$ & * & $*$ & * \\
\hline Foreign exchange rate exposures ................ & $*$ & * & $*$ & * & $*$ & $*$ & * & $*$ & * & * \\
\hline Other commodity and equity exposures ......... & $*$ & $*$ & $*$ & * & $*$ & * & $*$ & * & * & $*$ \\
\hline $\begin{array}{r}\text { Credit exposures } \ldots \ldots \ldots \\
\text { Other. } \ldots \ldots \ldots \ldots \ldots \ldots \ldots \ldots \ldots \ldots\end{array}$ & $\begin{array}{l}\text { n.a. } \\
.67\end{array}$ & $\begin{array}{ll}\text { n.a. } \\
.61\end{array}$ & $\begin{array}{l}\text { n.a. } \\
.67\end{array}$ & $\begin{array}{l}\text { n.a. } \\
.76\end{array}$ & $\begin{array}{l}\text { n.a. } \\
.64\end{array}$ & $\begin{array}{l}\text { n.a. } \\
.61\end{array}$ & $\begin{array}{l}\text { n.a. } \\
.57\end{array}$ & $\begin{array}{l}* \\
.58\end{array}$ & $\begin{array}{l}* \\
.50\end{array}$ & $\begin{array}{l}* \\
.44\end{array}$ \\
\hline Noninterest expense $\ldots \ldots \ldots \ldots \ldots \ldots \ldots$ & 3.57 & 3.54 & 3.57 & 3.55 & 3.52 & 3.48 & 3.49 & 3.53 & 3.52 & 3.44 \\
\hline Salaries, wages, and employee benefits.... & 1.78 & 1.79 & 1.82 & 1.82 & 1.81 & 1.79 & 1.82 & 1.84 & 1.76 & 1.64 \\
\hline 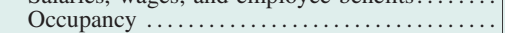 & .47 & .47 & .46 & .45 & .45 & .44 & .44 & .44 & .44 & .42 \\
\hline Other.................................. & 1.31 & 1.28 & 1.28 & 1.28 & 1.26 & 1.25 & 1.24 & 1.25 & 1.32 & 1.38 \\
\hline Net noninterest expense $\ldots \ldots \ldots \ldots \ldots \ldots \ldots$ & 2.26 & 2.24 & 2.18 & 2.09 & 2.14 & 2.15 & 2.18 & 2.19 & 2.33 & 2.42 \\
\hline Gains on investment account securities ......... & -.01 & .04 & .05 & .04 & .01 & $*$ & -.01 & $*$ & -.10 & .02 \\
\hline Income before taxes and extraordinary items..... & 1.61 & 1.46 & 1.60 & 1.53 & 1.55 & 1.60 & 1.55 & 1.31 & .42 & .02 \\
\hline 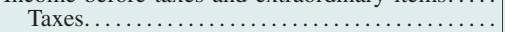 & .45 & .39 & .41 & .38 & .37 & .38 & .36 & .30 & .09 & .04 \\
\hline Extraordinary items, net of income taxes ...... & $*$ & $*$ & -.01 & & $*$ & & & . & $*$ & \\
\hline Net income $\ldots \ldots \ldots \ldots \ldots \ldots \ldots \ldots \ldots$ & 1.17 & 1.07 & 1.18 & 1.14 & 1.18 & 1.21 & 1.19 & 1.01 & .33 & -.02 \\
\hline Cash dividends declared ........................... & .79 & .64 & .68 & .67 & .64 & .67 & .65 & .67 & .57 & .36 \\
\hline Retained income..$\ldots \ldots \ldots \ldots \ldots \ldots \ldots \ldots$ & .38 & .43 & .50 & .47 & .54 & .54 & .53 & .35 & -.24 & -.38 \\
\hline Мемо: Return on equity...... & 11.52 & 10.28 & 11.49 & 10.97 & 11.25 & 11.54 & 11.14 & 9.18 & 3.03 & -.19 \\
\hline
\end{tabular}

NotE: Data are as of March 23, 2010

1. Effective October 1, 2008, the Federal Reserve began paying interest on depository institutions' required and excess reserve balances. Beginning with the 2008:Q4 Call Report, balances due from Federal Reserve Banks are now reported under "Interest-earning assets" rather than "Noninterest-earning assets."

2. Includes allocated transfer risk reserve.

3. Measured as the sum of large time deposits in domestic offices, deposits booked in foreign offices, subordinated notes and debentures, federal funds purchased and securities sold under repurchase agreements, Federal Home Loan Bank advances, and other borrowed money.

4. Measured as the sum of construction and land development loans secured by real estate; real estate loans secured by nonfarm nonresidential properties or by multifamily residential properties; and loans to finance commercial real estate, construction, and land development activities not secured by real estate.

5. Other real estate owned is a component of other noninterest-earning assets.

6 . When possible, based on the average of quarterly balance sheet data reported on schedule RC-K of the quarterly Call Report.

7. Includes provisions for allocated transfer risk.

* In absolute value, less than 0.005 percent.

n.a. Not available.

MMDA Money market deposit account.

RP Repurchase agreement.

MBS Mortgage-backed securities. 
A.2. Report of income, all U.S. banks, 2000-09

Millions of dollars

\begin{tabular}{|c|c|c|c|c|c|c|c|c|c|c|}
\hline Item & 2000 & 2001 & 2002 & 2003 & 2004 & 2005 & 2006 & 2007 & 2008 & 2009 \\
\hline Gross interest income.. & 423,845 & 404,251 & 349,603 & 329,218 & 348,667 & 426,600 & 551,085 & 616,994 & 565,232 & 480,744 \\
\hline Taxable equivalent & 426,479 & 406,937 & 352,351 & 332,000 & 351,651 & 429,556 & 554,341 & 620,456 & 567,906 & 483,511 \\
\hline Loans............... & 326,804 & 311,539 & 269,397 & 257,697 & 269,408 & 328,088 & 421,922 & 464,878 & 426,025 & 367,691 \\
\hline Securities .................... & 67,666 & 63,061 & 59,311 & 53,316 & 58,577 & 65,864 & 78,913 & 82,710 & 81,547 & 85,803 \\
\hline $\begin{array}{l}\text { Gross federal funds sold and reverse } \\
\text { repurchase agreements ........... }\end{array}$ & 13,546 & 12,647 & 6,221 & 5,015 & 5,142 & 11,045 & 21,288 & 28,682 & 16,642 & 3,565 \\
\hline 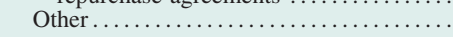 & 15,829 & 17,006 & 14,672 & 13,189 & 15,538 & 21,602 & 28,960 & 40,723 & 41,019 & 23,687 \\
\hline Gross interest expense . & 222,161 & 188,746 & 118,741 & 94,123 & 98,541 & 162,501 & 263,393 & 310,412 & 226,557 & 122,065 \\
\hline 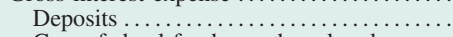 & 151,147 & 132,311 & 81,701 & 62,400 & 63,639 & 105,922 & 173,898 & 212,783 & 154,312 & 84,179 \\
\hline Gross federal funds purchased and & 26.860 & 19583 & 9020 & 7590 & 8842 & 19161 & 33776 & 37715 & 19755 & 4846 \\
\hline 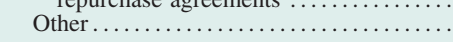 & $\begin{array}{l}20,000 \\
44,155\end{array}$ & 36,852 & 27,122 & 24,133 & $\begin{array}{r}8,842 \\
26,058\end{array}$ & $\begin{array}{l}19,101 \\
37,418\end{array}$ & $\begin{array}{l}53,1 / 0 \\
55,721\end{array}$ & $\begin{array}{l}3 /, / 13 \\
59,914\end{array}$ & $\begin{array}{l}19,153 \\
52,489\end{array}$ & $\begin{array}{r}4,840 \\
33,041\end{array}$ \\
\hline Net interest income..... & 201,684 & 215,505 & 230,862 & 235,095 & 250,126 & 264,099 & 287,692 & 306,582 & 338,675 & 358,679 \\
\hline Taxable equivalent & 204,318 & 218,191 & 233,610 & 237,877 & 253,110 & 267,055 & 290,948 & 310,044 & 341,349 & 361,446 \\
\hline Loss provisions. & 29,386 & 43,084 & 45,206 & 32,742 & 23,894 & 25,579 & 25,386 & 56,749 & 170,777 & 231,927 \\
\hline Noninterest income ........... & 153,101 & 160,902 & 168,236 & 183,792 & 188,999 & 201,768 & 222,901 & 218,554 & 209,052 & 245,173 \\
\hline Service charges on deposits & 23,720 & 26,872 & 29,629 & 31,692 & 33,454 & 33,830 & 36,194 & 39,187 & 42,542 & 41,000 \\
\hline Fiduciary activities ......... & 22,202 & 21,988 & 21,404 & 22,453 & 25,088 & 26,381 & 28,312 & 32,962 & 32,909 & 26,958 \\
\hline Trading revenue $\ldots . . . \ldots \ldots \ldots \ldots$ & 12,235 & 12,382 & 10,794 & 11,605 & 10,303 & 14,375 & 19,170 & 5,289 & $-1,235$ & 23,265 \\
\hline Other $\ldots \ldots \ldots \ldots \ldots \ldots \ldots \ldots \ldots \ldots \ldots \ldots \ldots$ & 94,945 & 99,658 & 106,410 & 118,042 & 120,154 & 127,180 & 139,226 & 141,116 & 134,839 & 153,952 \\
\hline Noninterest expense $\ldots \ldots \ldots \ldots \ldots \ldots \ldots$ & 216,375 & 225,979 & 230,128 & 243,214 & 263,304 & 274,136 & 294,891 & 321,406 & 357,254 & 356,135 \\
\hline Salaries, wages, and employee benefits & 89,016 & 94,196 & 100,447 & 108,446 & 115,254 & 124,038 & 135,869 & 144,700 & 147,502 & 152,289 \\
\hline Occupancy....................... & 26,762 & 27,939 & 29,311 & 31,314 & 33,253 & 35,051 & 36,393 & 38,531 & 40,896 & 41,622 \\
\hline Other................... & 100,598 & 103,846 & 100,368 & 103,453 & 114,797 & 115,048 & 122,630 & 138,177 & 168,855 & 162,224 \\
\hline Net noninterest expense. . & 63,274 & 65,077 & 61,892 & 59,422 & 74,305 & 72,368 & 71,990 & 102,852 & 148,202 & 110,962 \\
\hline Gains on investment account securities & $-2,280$ & 4,630 & 6,411 & 5,633 & 3,393 & -220 & $-1,320$ & -648 & $-16,432$ & $-1,651$ \\
\hline Income before taxes . & 106,741 & 111,971 & 130,176 & 148,563 & 155,322 & 165,933 & 188,995 & 146,334 & 3,264 & 14,141 \\
\hline 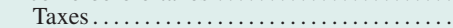 & 37,249 & 37,284 & 42,816 & 48,498 & 50,264 & 53,568 & 60,969 & 44,230 & 2,469 & 4,283 \\
\hline Extraordinary items, net of income taxes & -31 & -324 & -68 & 427 & 59 & 241 & 2,647 & $-1,672$ & 5,382 & $-3,845$ \\
\hline Net income & 69,461 & 74,363 & 87,291 & 100,494 & 105,115 & 112,604 & 130,674 & 100,431 & 6,178 & 5,220 \\
\hline Cash dividends declared ... & 52,547 & 54,844 & 67,230 & 77,757 & 59,523 & 64,624 & 82,360 & 85,266 & 43,327 & 43,445 \\
\hline Retained income .......... & 16,915 & 19,519 & 20,062 & 22,738 & 45,591 & 47,981 & 48,312 & 15,166 & $-37,150$ & $-38,226$ \\
\hline
\end{tabular}

NotE: Data are as of March 23, 2010. 